DEPARTMENT OF THE INTERIOR

UNITED STATES GEOLOGICAL SURVEY

GTEORGE OTIS SMITH, DIRÉCTOK

BULLETIN 374

\title{
MINERAL RESOURCES
}

OF THE

\section{KOTSINA-CHITINA REGION, ALASKA}

BY

FRED H. MOFFIT AND A. G. MADDREN

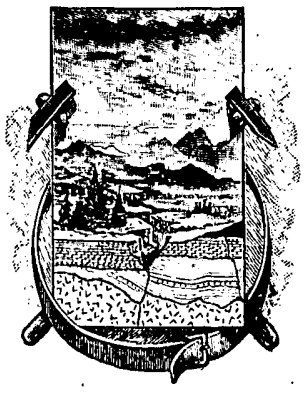

W A SHINGTON

GOVERNMENT PRINTING OFFICE

1909 



\section{CONTENTS.}

Geography and history

Position _-

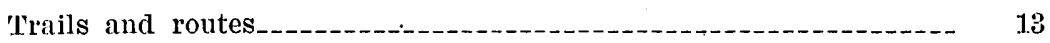

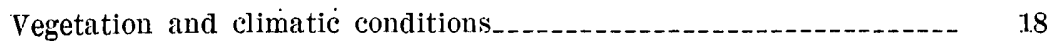

History _-_-_-_._- 19

General geology

Introduction _.

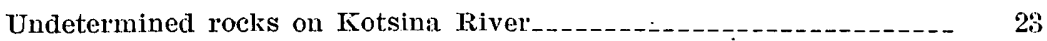

Nikolai greenstone-_-_-_. 23

Description _._. 28

Occurrence and distribution

Structure of the greenstone

Age of the greenstone

Chitistone limestone (Triassic)

Description _....-.....-. 25

Occurrence and distribution

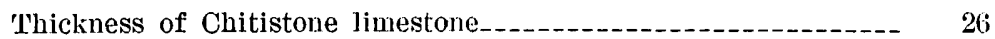

Age of the Chitistone limestone_._-_._- 26

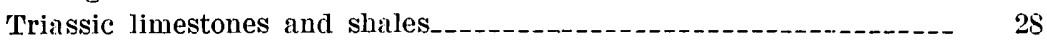

Description - .

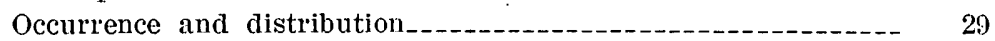

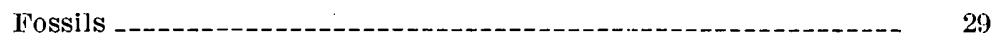

Disturbances following deposition of 'Iriassic

Kennicott formation -

Description _._-_._- 30

Occurrence and distribution_._._._- 30

Age of Kennicott formation

Post-Keunicott disturbance and erosion_-_-_-_-_-_-_-_-_-_-_-_-_ 32

Coal-bearing rocks__-_-_-_-_._. 32

Tertiary volcanic series_-_-_-_-_- 33

Description and occurrence-_-_._- 33

Thickness of volcanic series_-_-_-_-_- 33

Age of volcanic series_._- 34

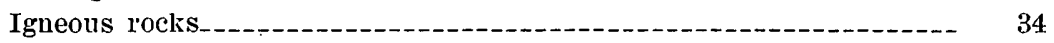

Preliminary statement

Granular rocks in the unmetamorphosed sediments_._-_.-_-_-- 34

Porphyries in the unmetamorphosed sediments_._._._._._._... 35

Andesite cutting the Triassic

Intrusive rocks in Tertiary volcanic series.-_- 36

Andesite flows 
General geology-Continued. Page.

Faults _.

Pleistocene and Recent deposits 37

Introduction _._.

Present features_._._. 35

Pre-Pleistocene land surface._._. 38

Frosion and deposition during Pleistocene and Recent time... $\quad 39$

Character of the valley-plain deposits__._. 41

Economic geology

General statement _._.

Copper _._._-

'The copper minerals_____... 44

Preliminary statement _... 44

Native copper._._. 44

Cuprite -

Tenorite -

Chalcocite _. 45

Bornite _.

Chalcopyrite _. 46

Malachite _._. 46

Azurite -

Chalcanthite__._._._. 47

Occurrence of the ores_. 47

General statement._._-_._._. 47

Copper sulphide deposits in greenstone and limestone....._ 48

Native copper associated with the greenstone._._._._._.- 50

Placer copper._. 50

Source and character of the copper deposits_._. 50

Description of properties_.

Kotsina River basin

Kotsina River._._.

Ames Creek._. 55

Rock Cieek_... 55

Roaring Creek._._. 56

Peacock Creek_____. 57

Rose claim._._. 57

White Dog and Mint claims___._._. 58

Mountain claim__._._. 58

Shower Gulch ___ 58

Surprise Creek

Laddie claim_._. 60

Sheehan claim_._._. 60

Hubbard claim.- 60

Kluvesna Creek____. 60

Copper Creek_._._. 62

Elliott Creek

General description____._. 63

Copper King and Mineral King claims________ 65

Claim at the head of Queen Creek__._._._._. 66

Van Dyke claim_._......_._. 66

Copper Queen claim_._. 66

Marmot claim____._._. 66

Louise claim_._. 67 
Economic geology-Continued.

Copper-Continued.

Description of properties-Continued.

Kotsina River basin-Continued.

Elliott Creek-Continued.

Page.

Lizzie G claim___._._._._. 67

Goodyear and Henry Prather claims..._........ (it

Elizabeth claim_._._._._.

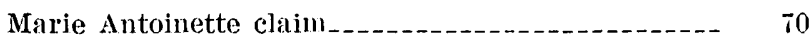

Albert Johuson daim_... i0

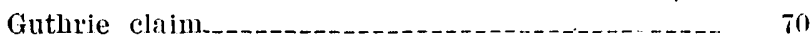

Leland and Lawton claims._._._.............. 71

Cliff claim________

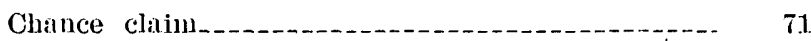

Kuskulana River balsin_____._.

General description

Nuggett Creek,

General outline........................................

Valdez claim _........ $7: 3$

One Girl claim _..........

Strelna Creek _.............. 74

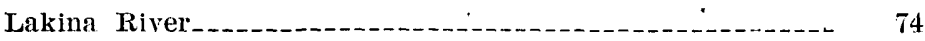

Kennicott River basin

Hidden Creek _._._._.

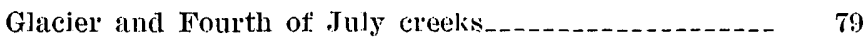

Nebraska claim_..........- 79

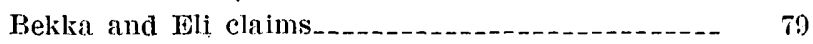

Bonanza Creek _...... 80

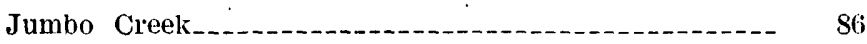

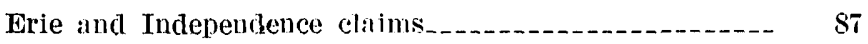

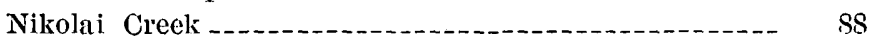

Chitistone River basin__._.

Main stream _...

Glacier Creek _._. 91

Dan Creek _._.

Gold _-_-

The Nizina placers _._.

Location and history

Geological sketch

Chititu Creek -

Dan Creek _........ 97

Realgar -_.

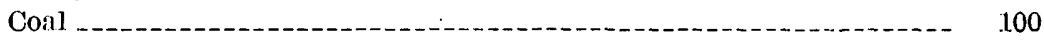

Index - 


\section{ILLUSTRATIONS.}

Plate I. Topographic reconnaissance map of Chitina River and Copper

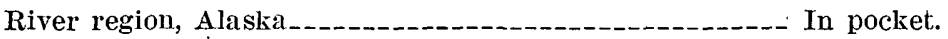

II. Geologic reconnaissance map and sections of the Chitina copper belt, Alaska In pocket.

III. $A$, Contact of Nikolai greenstone and Chitistone limestone west of Nizina River, near Nikolai mine; $B$, Sheared greenstone on south side of Kotsina River below Surprise Creek

IV. A, Thin-bedded Triassic limestone and shale on west branch of Rock Creek; $B$, Crumpling in thin-bedded Triassic limestone on ridge east of Gilahina River-

$\checkmark$. Head of Nikolai Creek

VI. $A$, Intrusions of fine-grained porphyry in black shale on Young Creek; $B$; Castle Mountain

VII. $A$, Pleistocene gravel bluffs along north bank of Chitina River; $B$, Chitistone limestone on the. north side of Elliott Creek

VIII. View of Bonanza mine from Horseshoe trail_._-_._._.......-

IX. $A$, View of the Nikolai vein and shaft; $B$, View along the vein of the Henry Prather claim

X. $A$, Contact of the Chitistone limestone and Nikolai greenstone formations on east side of Nizina River; $B$, View across Nizina River into Dan Creek

Figure 1. Comparative grades of the four proposed railroad routes from the coast to the interior Copper River basin____._._-_. 16

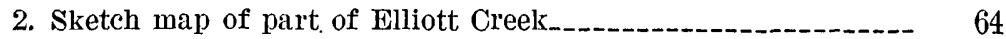

3. Cross section of the Elliott Creek anticline

4. Diagram showing the relation of the faulted portions of the Goodyear claim, Elliott Creek-_..-_- 68

5. Sketch map of the Bonanza mine_....... 81

6. Form of ore body exposed in the main or northern tunnel at the Bonanza mine

7. Form of ore body exposed in the southern tunnel at the Bonanza mine

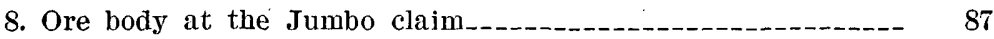

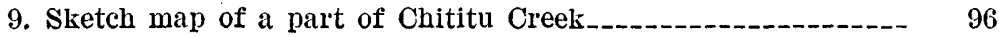




\section{PREFACE.}

By Altred H. Broors.

Native copper from the district described in this volume is the first mineral reported from Alaska. Steller, the naturalist who accompanied Bering on his voyage of discovery in 1741, noted the use of copper knives among the natives of Kayak Island. This copper undoubtedly came from the Chitina-Kotsina belt. Among the Alaskan natives the use of copper was widespread, for it was the only metal utilized by them, but apparently the century of occupation by the Russians passed without any search on their part for the locality from which the supply was derived. The only attempt made by the Russians to explore the Copper River (Serebranikof, 1847) resulted in the massacre of the whole party by the Indians.

The first successful explorations were madę by Allen (1885) and by Schwatka and Hayes (1891), and the first systematic surveys were carried out by Schrader of the United States Geological Survey and his associates in 1900 .

It is part of the Survey's plan for the investigation of the mineral resources of Alaska to keep the work abreast of the mining developments in each district so far as the means available will permit. As a great deal of prospecting, which has developed many new facts in regard to the occurrence of ore, has been done in the Chitina Valley since 1900 , and as the valley has become a focal point of interest to those who are considering railway construction into the interior, a reexamination of the copper belt seemed to be necessary. A new report was, furthermore, justified by the fact that the edition of Schrader and Spencer's report, published in 1900, is now out of print.

The portion of the present volume which treats of the general geology is to be regarded as a revised edition of that report, which has been of incalculable value as a guide to the prospectors. The geologic map which resulted from Schrader and Spencer's very hasty reconnaissance has stood the test of seven years of active prospecting, and the authors of the present report, Messrs. Moffit and Maddren, after a careful reexamination of this district, have made but few changes. 
The topographic map accompanying this report, based on the surveys of Gerdine and Witherspoon in 1900 and 1902, and of Hamilton and Hill in 1905, has been entirely redrawn, with the aid of the data afforded by several railway surveys and of the work of the Coast and Geodetic Survey along the seaboard.

The description of the occurrence of mineral deposits is entirely by Moffit and Maddren, but their work was much aided by the earlier studies of Schrader, Spencer, and Mendenhall.

This second report on the copper belt can be regarded as only another step toward the solution of the many problems connected with the economic geology of the region. Detailed surveys will be necessary before the problems can be submitted to an ultimate analysis. For this reason there is in preparation a detailed topographic map of the eastern end of the field, in which the deepest mining has been done and which seems to afford the best opportunity for solving the geologic problems. The detailed geology of this area will be studied as soon as means will permit, for it is believed that such a study will throw light on the occurrence of copper throughout the field. 


\title{
MINERAL RESOURCES OF THEE KOTSINA-CHITINA REGION, ALASKA.
}

\author{
By Fred H. Moffit and A. G. Maddren.
}

\section{INTRODUCIION.}

The increased demand for copper and its prevailing high price, due chiefly to remarkable advances in the use of electric power, have, during the laist few years, attracted much attention. to the copper deposits of Alaska. Copper has been found in many parts of Alaska, but at present only three regions or districts give promise of making any important contribution to the copper market. These regions are Prince of Wales Island in southeastern Alaska, Prince William Sound, and the Copper River-Chitina River region. The first two regions have produced copper for several years, as their mines are situated near the ocean and enjoy cheaper transportation facilities, but the interior region is still in the prospecting stage and will remain so till a better and more economical means of handling supplies and ore is provided.

The investigations of the Geological Survey in the interior copper region during 1907 were carried-on in its southern portion, which includes. Kotsina River and most of the northern side of Chitina River valley. This work was a continuation of the investigations of Schrader and Spencer in 1900, and with the results of their study in hand greater headway was made than would otherwise have been possible. The work consisted chiefly of visits to the various copper prospects and investigations of the occurrence of copper, but the study of the regional geology was continued, so far as it could advantageously be carried on. A second object of the expedition was an investigation of the Nizina gold placers. The party landed at Valdez in the middle of June, but, owing to the necessity of making double trips with the summer's supplies and to other delays, field work was not begun till July 10, when Elliott Creek was reached. From that time till the last of September it was continued with little interruption, so that nearly eighty days were included in the 
field season, of which much the greater part was devoted to a study of the copper deposits.

Exploration in the Chitina River valley was begun in 1885, when Lieut. (now Maj.) Henry T. Allen, in the course of a remarkable journey from Prince William Sound to St. Michael, during which he traversed portions of the valleys of Copper, Tanana, Koyukuk, and Yukon rivers, ascended Chitina River on the ice from Taral to Nikolai House near the mouth of Dan Creek. Lieutenant Allen made a reconnaissance route map of the region through which he went and in his report mentioned the occurrence of copper in the vicinity of Chitistone River, or Nizina River, as it is now called.

In 1891 Lieut. Frederick Schwatka, U. S. A., and C. Willard Hayes, of the Geological Survey, both acting in a private capacity, entered Chitina River valley by way of Skolai Pass. They descended Nizina River nearly to Dan Creek on foot, but after building a canvas boat continued their journey down Nizina, Chitina, and Copper rivers to the coast. They also made a reconnaissance route map of their traverse. In 1899 a party in charge of Oscar Rohn explored the region south and east of Mount Wrangell. This party. was a detachment from the military exploration in charge of Capt. W. R. Abercombie.

In 1900 a geologic and topographic reconnaissance of the Chitina and Hanagita valleys and of the lower Copper River was made under the direction of Frank C. Schrader, of the Geological Survey. The topographic map was made by T. G. Gerdine and D. C. Witherspoon. The geologic investigations were carried on by F. C. Schrader and Arthur C. Spencer. This work, although hastily done, owing to the difficulties of travel and the necessity of covering the greatest possible area in the time available, has nevertheless been of very great value to prospectors of the region.

Two years later, in 1902, Walter C. Mendenhall, of the Geological Survey, during an investigation of the geology and mineral resources of the central Copper River region, visited the copper prospects of Kotsina River and Elliott Creek.

A list of the publications resulting from the work of these expeditions is here given:

AlleN, Lieut. Henry $\mathrm{T}$. Report of an expedition to the Copper, Tanana, and Koyukuk rivers, in the Territory of Alaska, in the year 1885. Washington, Government Printing Office, 1887.

HAYES, C. Willard. An expedition through the Yukon District: National Geographic Magazine, vol. 4, 1892, pp. 117-162.

RoHn, Oscar. A reconnaissance of the Chitina River and the Skolai Mountains : Twenty-first Ann. Rept., U. S. Geol. Survey, pt. 2, 1900, pp. 393-440.

Schrader, Frank Charles, and Spencer, Arthur Coe. The geology and mineral resources of a portion of the Copper River district, Alaska. Special publication of the U. S. Geological Survey, 190 s. 
Mendeneald, Walter C., and Schrader, Frank C. The mineral resources of the Mount Wrangell district, Alaska : Prof. Paper U. S. Geol. Survey No. 15, 1.903.

Mendenhall, Walter C. Geology of the central Copper River region, Alaska : Prof. Paper U. S. Geol. Survey No. 41., 1905.

\section{GEOGRAPHY AND HISTORY.}

GEOGRAPHIC POSITION.

The Kotsina-Chitina region, as represented on the topographic and geologic map made under Schrader's direction in 1900 (Pl. II), is included in a quadrangle bounded by parallels $61^{\circ}$ and $62^{\circ}$ north latitude and meridians $142^{\circ}$ and $145^{\circ}$ west longitude. This map does not, however, include all the area surveyed that year, since the trail from Valdez to Copper River, the lower Copper River, and the upper portion of Tana River are omitted (Pl. I).

Copper River is joined about 100 miles from its mouth by its large eastern branch, Chitina River, whose general course is nearly westnorthwest. On ascending the main branch of the Copper it is found that the river first bears to the northwest, then swings northeast, and finally southeast. Thus the two branches of Copper River, the Chitina and the upper Copper, nearly surround the Wrangell Mountains. The area included between these two streams and the heads of White, Chisana (or "Shusana"), and Nabesna rivers is generally referred to as the Copper River copper region. It is divided into a northern and a southern district by the Wrangell and Skolai mountains, whose ice-covered ridges form an almost impassable barrier between them. This paper deals with the southern district only.

The Wrangell Mountains are a somewhat detached or partly isolated mass, bounded on the north, west, and south by valleys whose trend is west-northwest and east-southeast. To the southeast. they merge into the Skolai Mountains, and these in turn unite with the St. Elias Range. Their summits rise to altitudes ranging from 8,000 to more than 16,000 feet, and reach their greatest elevation in such peaks as Regal Mountain (13,400 feet), Mount Blackburn (16,140 feet), and Mount Wrangell (14,005 feet), all of which are visible from Chitina Valley. Mount Drum (12,000 feet) and Mount Sanford (16,200 feet) are conspicuous in upper Copper River valley, but are hidden on the south by the other peaks mentioned.

The lofty summits of these mountains and the ridges that join them are the gathering places for snows that feed the numerous glaciers that creep down their sides and out into the valleys at their feet. These snow fields and glaciers are the sources of nearly all the large tributaries of Chitina River. A glance at the map (Pl. I) will show the great difference between the quantities of water supplied to the river from the two sides of its drainage basin. 
Nizina, Lakina, Gilahina, and Kuskulana rivers are the largest northern tributaries of the Chitina. Kotsina River, which joins the Copper 2 miles above the Chitina's mouth, and is therefore not a tributary of the latter stream, is also fed by the glaciers. The largest southern tributaries to Chitina River are Tana River, heading. in a glacier of the mountains between Chitina Valley and the coast, and Chakina and Tebay rivers, draining Hanagita Valley.

The Chitina Valley floor is a broad, gravel-covered, lake-dotted flat land expanse with a maximum width of at least 10 miles, whose surface is broken here and there by low round-topped hills and by deep canyons of streams which cross it. Chitina River, in the lower 50 or 60 miles of its course, has cut a deep broad channel in the valley floor, and for most of that distance it flows close to the foot of the mountain slopes on the south. The flood plain in places, particularly along the river's lower course, reaches a width of 1 mile, and is bounded on one or on both sides by banks-in some places gravel, in other places hard rock-which gradually decrease in height downstream, but which have an average height of between 100 and 200 feet. Over this gravel flood plain the river flows in numerous branching subchannels, whose positions are constantly changing, and are particularly unstable at the time of spring floods, so that those who follow them one year may find them entirely different the next year. The current is swift, rarely less than 6 or 7 miles per hour.

About 45 miles above its mouth Chitina River forks, the southern branch retaining the name Chitina, and the northern being known as Nizina River. The northern branch is almost as large as the southern and drains nearly half of the copper-bearing region. For 2 or 3 miles above its mouth Nizina River flows through a deep, narrow, winding box canyon, cut through solid rock. Above this for 8 or 10 miles the canyon is much less pronounced, the walls in places being steep gravel banks instead of rock cliffs. Still farther upstream the canyon gives way to a wide gravel flood plain, which gradually narrows and leads into the open glaciated mountain valley of the upper river. Each of the important headwater tributaries of Nizina River, except Dan and Chititu creeks, has a glacial origin.

This general description might be applied with slight modification to all the large northern tributaries of Chitina River, and to Kotsina River also. All except Gilahina River spring from glacial sources, traverse broad, gravel-floored glaciated valleys in the mountain district, and finally cross the Chitina Valley in deep canyons before joining the main river.

They drain an area of exceedingly rugged topography, whose sharp outlines are softened only in the vicinity of Young Creek. Between Hanagita Valley and Chitina River the mountains are lower and less 
rugged, and lack the snow fields and glaciers so commonly seen in the Wrangell Mountains. The streams are smaller, and descend through steep gulches to the river. South of Hanagita Valley are other lofty snow-capped sierras, forming part of the Coast Range, but they are beyond the limits of the area under consideration.

\section{TRAILS AND ROUTES.}

The Kotsina-Chitina region may be reached from Valdez in summer by the Government trail between Valdez and Eagle, and in winter either by the same route or by way of Tasnuna and Copper rivers. One may also enter the region from Eagle or Fairbanks by the Government trail, but these routes are used only by those already in the interior. Skolai Pass is now frequently crossed by those going from Nizina River to the head of the White, or in the opposite direction, and it is reported that two prospectors went from Yaktag on the coast to Chitina River by way of the Tana River glacier. Neither of these, however, is a practicable route of travel. Up to the present Valdez has been the coast point from which all supplies were taken into the Copper River region. The Government trail is the route always followed in summer, and is the one usually chosen in winter. Leaving Valdez the main trail is followed till Tonsina River bridge is crossed. From there a second trail leads eastward about 25 miles along the high bluff north of Tonsina River to Copper River. The total distance from Valdez to Copper River by this route is approximately 1.00 miles.

Copper River is crossed at a point 2 miles above the mouth of Tonsina River. An Indian named Billum has a ferry license and transfers travelers with their baggage in two small boats. Horses must swim the river. After crossing Copper River the trail follows the east bank 6 miles to Billum's lower cabin and then, leaving the river, proceeds northeast 3 miles to Horse Creek. At Horse Creek it divides, one branch leading northeast to upper Kotsina River and Elliott Creek, the other southeast to the copper camps and gold placers of Chitina Valley.

The Tasnuna-Copper River route from Valdez to Chitina River can be used only when the river is frozen over, for the trail is on the ice all the way after leaving Tasnuna River. Supplies for the Chitina Valley leave Copper River on reaching Chitina River and are carried up that stream. Those destined for Kotsina River and Elliott Creek continue up the Copper to the summer trail at Billum's lower cabin. The great advantage of the Tasnuna River route is the saving of time under favorable conditions by the possibility of hauling heavy loads. A snow plow is used to break a trail, over 
which the freight is hauled on heavy bobs in place of the narrow double-ended sleds employed elsewhere. This advantage may be entirely offset, by the loss of time due to the fearful winds which sweep down the river and prevent any travel for days at a time. The Government trail has the advantage of being kept open all winter, since it is the mail route and is traveled regularly. Its chief difficulty lies in the crossing of Thomson Pass.

Returning now to the Kotsina-Chitina area: Of the two trails leading from Horse Creek-the Kotsina trail and the Chitina Valley trail-the Kotsina trail proceeds northeastward to Willow Creek, a small tributary of Kotsina River, where a branch trail, after the Hubbard-Elliott bridge over the Kotsina has been crossed, leads over a steep spur of Hubbard Peak to Elliott Creek. . The main trail continues along the right, or west and north, bank of Kotsina River into Kotsina Valley. The stream issuing from Long Glacier is crossed on ice at the glacier's lower end; and bridges over Kluvesna River and over Kotsina River near Rock Creek obviate most of the difficulties and dangers formerly offered by these streams.

The Chitina Valley trail runs southeastward from Horse Creek, and reaches Kotsina River at a point 8 miles below Willow Creek. A bridge recently built by the Government at this place does away with another dangerous ford. From the government bridge the trail continues eastward along the Wrangell Mountain foothills, crossing Kuskulana River 3 miles below the glacier, and reaching Chokosna River and the Lakina by way of Kuskulana Pass. Ascending Fohlin Creek, it proceeds by way of Bear Creek and Fourth of July Creek to Kennicott Glacier and Kennicott River, which is crossed on the glacier ice. A good trail has been built from the glacier's lower end to the Bonanza property. Another trail ascends McCarthy Creek 4 miles and, crossing the ridge known as Sourdough Hill, lands one on Nizina River at a place from which Chititu Creek, Dä Creek, and Chitistone River are reached with ease when once the Nizina has been forded. There are no bridges east of Kotsina River, and the streams being of glacial origin are very cold and subject to great and rapid changes in the quantity of water carried, but the only ones likely to cause trouble are the Kuskulana, Lakina, and Nizina.

Most prospectors leaving the Nizina country descend Chitina and Copper rivers in small boats, either leaving the Copper at Tasnuna River and going overland to Valdez or following the river to the coast and landing in Eyak or Orca. Several days' work is required for whipsawing lumber and building a boat, but even then the river trip is much easier and quicker than the trail. The trip from the mouth of Young Creek to Tasnuna River, over 115 miles, 
has been made in less than twenty running hours. A skillful boatman would meet with little or no difficulty on the Copper or Chitina, but the canyon at the lower end of Nizina River is dangerous, particularly at low water, and a number of persons have been drowned in trying to run through it.

In July, 1907, a small steamboat called the Chitina made her first trip from Tasnuna River to Copper Center, on Copper River, and to the Nizina; on Chitina River. Material for her construction was carried over the snow from Valdez during the previous winter, and she was completed early in July, but after the trip up the river was hauled out on the bank for the winter. She draws very little water, but will probably be unable to run after the middle of summer, because the Chitina is much lower in the fall than during the spring and early summer. She can not descend Copper River farther than Abercrombie Rapids, 25 miles below Tasnuna River, and any freight she may carry up the river must be delivered to her either at the rapids or at Tasnuna River.

The mineral resources of the Copper River region will remain undeveloped until a more reliable and economical means of transporting freight to and from it has been provided, and since Copper River can never become a highway of communication, such as the Yukon is for the northern country, no important copper production can be expected till a railroad has been constructed to connect the copper-bearing area with a coast point. On the other hand, it is hardly possible that such a road would be profitable until the region reaches a stable productive stage. The success of the one then appears to depend on the establishment of the other, and it is not strange that the future of each has so far been more or less in doubt.

There has been no lack of projects for the building of a road. Some have even been carried to a point where their accomplishment seemed almost assured and yet have fallen through. Nevertheless, it is probable that within a few years there will be railroad communication between the coast and the lower limit of steamboat navigation on Copper River.

Four railroad routes to the interior are possible and have been considered by those interested in building a road. Preliminary surveys, furthermore, have been made over each. Each route overlaps some one of the others in part of its course and all have difficulties to surmount. Two of the four routes originate from Valdez and two from points adjacent to the mouth of Copper River. The first one from Valdez is practically that of the government trail. It follows Lowe River to Thomson Pass, over which it proceeds to the head of Tsina River, or South Fork of Tiekel River, as it is more generally called, and then continues northward to Tonsina. The sec- 
ond ascends Lowe River to its head, crosses Marshall Pass to Tasnuna River, and after descending that stream follows the west bank of Copper River northward. Of the two strictly Copper River routes one starts from Cordova Bay in Prince William Sound, 24 miles west of the river's nearest point; the other from Katalla, nearly 17 miles southeast of Cottonwood Point, the southern extremity of Copper River's east bank.

There are not sufficient data at hand for a thorough discussion of these routes, but some of their advantages and difficulties may bo pointed out. It will be seen that there are some discrepancies between distances given here and elsewhere, arising from the use of railroad surveys in connection with small-scale maps. The given elevations,

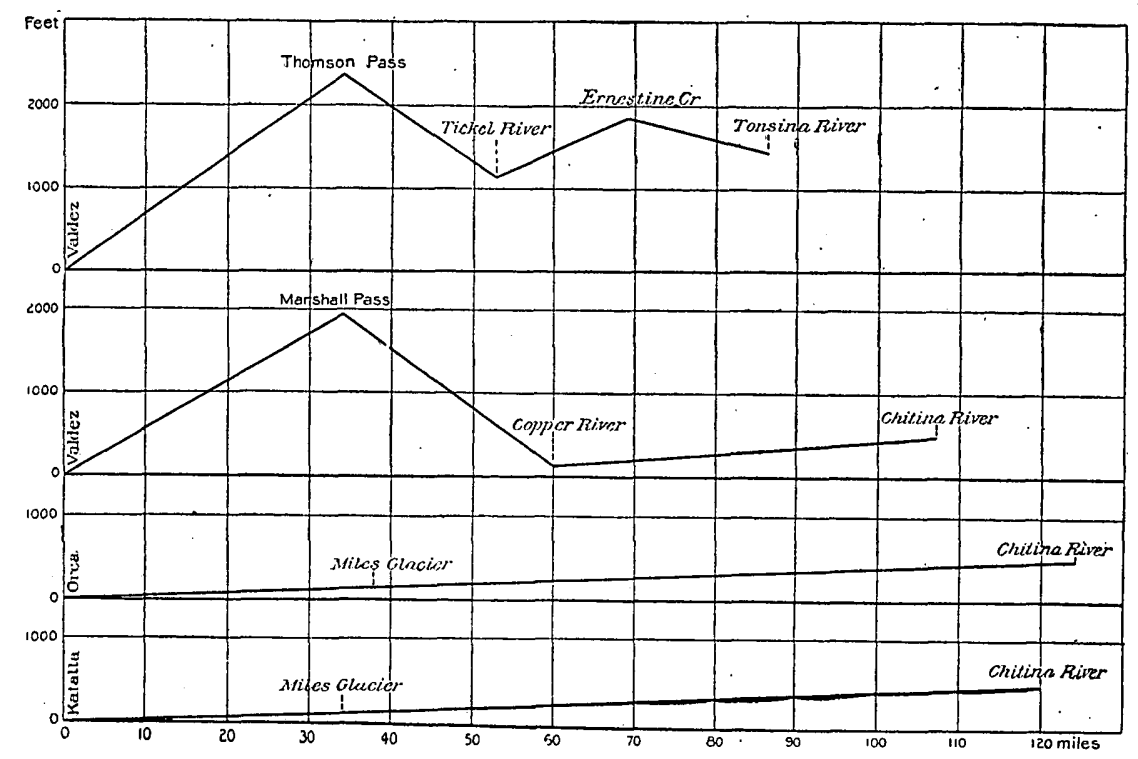

NiG. 1.-Comparative grades of the four proposed railroad routes from the coast to the interior Copper River basin.

too, take no account of minor grades and are therefore minimum quantities-less than the total number of feet a locomotive must rise in going from tide water to the interior points indicated.

The Tonsina route has the most difficult grades. (See fig. 1.) From Valdez to Thomson Pass, 34 miles distant by the railroad surveys, there is a climb of 2,370 feet. Then comes a descent of 1,250 feet in 19 miles to Tiekel River, followed by an ascent of 710 feet in 16 miles to the Ernestine divide. From Ernestine to Tonsina, 16 miles, there is a descent of about 400 feet. It will be seen that the total of the distances here given is 86 miles, or 6 miles greater than the distance from Valdez to Tonsina given by the road commission. 
The greatest obstacles encountered on this route are the Keystone Canyon of Lowe River and Thomson Pass, by which the coast range is crossed. These involve a great deal of rockwork and are subject to deep snows and snowslides in winter. The latter difficulty, however, will be met on any route.

Less difficult grades are presented by the Tasnuna route. From Valdez to Marshall Pass, 34 miles, there is a rise of 1,860 feet. Then comes a fall of 1,740 feet in 26 miles to Copper River. From Tasnuna River mouth to Chitina River, 47 miles, is an ascent of 370 feet. The difficulties of Keystone Canyon are encountered on this route also, but Marshall Pass is 500 feet lower than Thomson Pass, and the heavy grade from Tiekel to Ernestine is avoided.

The two Copper River routes have practically the same grades (see fig. 1), a rise of 480 feet between the coast and Chitina River. The distance from Katalla to Chitina River is 120 miles, and from Eyak or Cordova Bay slightly farther, about 124 miles.

A railroad from Katalla involves the construction of a harbor available at all seasons where ships can discharge their cargoes in safety. A bridge over Copper River is required immediately above Childs Glacier, but there is no rockwork, except a mile or two at Katalla, till Abercrombie Rapids have been reached. Two railways are located and under construction at Katalla. One runs west from the town and then northwest to Copper River, but has a spur up Katalla River to Bering Lake and the coal fields; the other ascends Katalla River and reaches Martin River, which it descends to the Copper by the Lake Charlotte divide. The Lake Charlotte route thus passes through the coal field. Each of these Katalla roads has its own plans for a separate breakwater and terminal facilities.

Cordova Bay, in contrast with the open roadstead of Katalla, is a protected body of water that can be entered at any time, but a road from this place involves rockwork below Abercrombie Rapids and two bridges over Copper River in order to avoid Childs Glacier. Furthermore, it will be necessary to build a branch line to the coal fields. The upper bridge, between Childs Glacier and the little lake fronting Miles Glacier, can probably be built without unusual trouble, since it is not long and the foundations are believed to be good, but as to the bridge below Childs Glacier there is uncertainty that will not be removed till the nature of the river's bottom has been more fully examined.

Northward from Abercrombie Rapids the Katalla and Cordova Bay routes are the same, and above Tasnuna River they also coincide with the Valdez-Tasnuna route, following the river's steep west bank. Immediately above the rapids is the moraine or stationary débriscovered lower end of Baird Glacier. This is overgrown with a thick 
growth of alders and extends down to the river's edge, where the underlying ice has been exposed occasionally in test pits. It is known as "dead glacier" and must be traversed for several miles by any road following the west side of Copper River. The surface is sometimes disturbed by melting of the ice beneath, but whether this will cause serious difficulty in maintaining the track is perhaps doubtful. Between Baird Glacier and Chitina River much of the roadbed must be cut from the solid rock, but it is not believed that any unusual engineering difficulties will be met.

A great advantage of the two Copper River routes, in addition to their lower grades, is their nearness to the Controller Bay coal fields. This is doubtless one reason why they are regarded with greater favor than the shorter routes from Valdez.

\section{VEGETATION AND CLIMATIC CONDITIONS.}

Chitina Valley is a timbered region and furnishes a supply of wood suitable for most of the miner's requirements. The greater part of the timber is spruce, but cottonwood is abundant on many river banks and deltas; and though it is of little value for lumber, it is nevertheless useful for some purposes. The broad, marshy, valley lowland supports a scanty growth of very inferior spruce and of aspen. Better timber grows along the borders of the lowland and on the lower mountain slopes. It covers the slopes to an elevation varying from 2,000 to 3,000 feet above sea level, but trees growing near timber line are of course dwarfed and of little use except for firewood. Near glaciers or in the narrow valleys leading to them the timber line does not reach as great an elevation as on the interstream slopes. Some of the best timber in the valley grows in the vicinity of Chititu and Young creeks. Trees 18 inches in diameter at the butt and tall enough to give two 16-foot cuts are not unusual, but the large majority of them are smaller than this.

South of Chitina River between Nizina River and the Copper there is a heavy growth of spruce on the north slopes of the mountains. It is of much poorer quality, however, than that on the Wrangell Mountains. The wood is brittle and has little strength. Most of the trees, too, are of small diameter and will probably be of more value as fuel for the steamboat Chitina than for any other purpose.

Inadequate and expensive means of transportation have been the chief obstacle in developing the copper resources of Chitina Valley, but another adverse condition, which, however, affects prospecting more than mining, is the short summer season. Up to the present practically all supplies have been carried during the winter with sleds drawn by horses. In the earlier days dogs, or even man power, 
were sometimes used, but in later years horses have been employed almost entirely. Sufficient feed to last till grass starts in the spring is carried in from the coast, but after spring most horses "live on the country." Early snows come about the end of August, so that between a late spring and an early winter horses can not be expected to find their own feed longer than from approximately the first of June till the first of September. Grass is always abundant near timber line in June, July, and August, and good pasture is usually found at lower elevations after the timber has been burned off for a number of years. Some of the prospectors have provided their stock with fine feed by following this practice of burning off the timber. Horses frequently have difficulty in finding feed in the timbered valley bottoms, even in midsummer, but in the fall, after frost has killed the grass on the mountains, the river bars afford a plant known locally as "pea vine," of which horses are very fond and which is excellent forage. Since most prospectors use at least one or two horses for packing in summer and for hauling supplies in winter, it is readily seen that the matter of horse feed has a great influence in determining the number of available working days in a summer. The prospecting season is still further shortened by the fact that in the high mountains, where most of the copper ores have been found, much snow often remains till the first or even the middle of July.

Figures for the yearly precipitation and temperature are not available, but it may be said that the extremes of temperature in summer and winter are much greater than on the coast and that the rainfall is very much less.

\section{HISTORY.}

Native copper from the Chitina (chiti=copper and $n a=$ river) Valley was used by the Copper River Indians before white men entered the country. Spear and arrow heads of copper were made by them and have been found in the sluice boxes by miners on Chititu and Dan creeks. Ceremonial knives of copper are even now employed by the natives for cutting the first salmon caught in the beginning of the season's run. Lieutenant Allen relates that Nikolai showed him specimens of bornite and told him of native copper on Chititu Creek. He also showed him bullets of native copper obtained from natives "over the mountains," probably at the head of White River. A much-worn wooden shovel and birch bucket, found in the loose waste below an outcrop of native copper in amygdaloidal greenstone on Glacier Creek, a tributary of Chitistone River, indicates that the Indians also knew of native copper in place at that point. Whether they had any knowledge of the presence of gold on Chititu and Dan creeks is not known to the writers. 
White prospectors first appeared in the Chitina Valley in 1898, their presence resulting from the general interest aroused in Alaska by the discoveries at Dawson two years before. Spencer, ${ }^{a}$ after visiting the region in 1900 , says:

The occurrence of rich copper deposits within the basins of Copper and Chitina rivers has been commonly reported for many years, but it was not until the summer of 1898 that efforts to locate ores proved successful. In this year several prospectors reached the interior and made some locations, while in 1899 a number of men penetrated the Wrangell Mountains by way of Kotsina River and discovered good indications at many places; others, exploring toward the east, proved the continuance of the copper-bearing belt in the direction of White River, where copper occurs in important quantities. In this region the Nikolai mine was discovered in July, 1899, under the guidance of a native sent by Chief Nikolai. During the summer of 1900 several prospecting parties were operating in the Kotsina and Chitina regions, and many additional locations were made, and upon the most promising properties considerable development work was done.

The Bonanza was discovered about the end of July or the first of August, 1900, by two prospectors, Clarence Warner and Jack Smith, who staked the property. It was discovered independently two or three weeks later by A. C. Spencer, of the Geological Survey party, who found it while tracing the limestone-greenstone contact eastward from Kennicott Glacier. Warner and Smith were members of a party acting under an agreement to share whatever minerals might be discovered. Some of the men were also bound to divide their interest with others, not members of the party, who had furnished them with supplies - " grubstaked" them. In consequence of this complication of ownership the property became involved in litigation that was not settled for several years.

The Nizina gold placers were discovered in 1901, but the rush of prospectors to the region did not begin till the following year. A large number of men left Valdez for the upper Chitina in June and July, 1902, and Dan, Chititu, and Young creeks, besides others, were prospected and staked. After the richest and more easily handled gravels were worked over the claims were sold or abandoned and gradually came into the hands of fewer individuals, so that now most of the claims on Dan and Chititu creeks are included in three separate ownerships. There has been little mining on Young Creek.

\section{GENERAL GEOLOGY.}

\section{INTRODUCTION.}

In the following account of the geology of the Kotsina-Chitina region the descriptions are confined to the area between Chitina River and the summits of the Wrangell and Skolai mountains rep-

"Schrader, F. C., and Spencer, A. C., The geology and mineral resources of a portion of the Copper River district, Alaska; a special publication of the U. S. Geol. Survey, 1901, p. 82 . 
resented on the geologic map (Pl. II). This map is reproduced from the report of Schrader and Spencer (1901), but has received such corrections in some of its lesser details as were indicated to be necessary by the later work of Mendenhall (1902) and by the more recent work of the Survey party in 1907. The formation names used by Schrader and Spencer on the map and in the description are here retained.

In outline the important facts concerning the geology are as follows: Both sedimentary and igneous rocks are encountered. Four principal formations, including the unnamed Triassic shales and limestones, occupy most of the area and appear throughout its length from east to west. These formations, in order from oldest to youngest, are the Nikolai greenstone, the Chitistone limestone, the Triassic limestones and shales, and the Kennicott formation. These rocks have been folded and faulted, but the metamorphism is not great. It is most noticeable in the greenstone but has hardly affected the Kennicott formation.

The Nikolai greenstone consists of a succession of basaltic lava flows and is overlain conformably by the massive Chitistone limestone. This limestone is of Triassic age and is succeeded without any known interruption in deposition by other Triassic rocks-limestones and shales-consisting of a lower member made up of interbedded thin limestones and black or gray shales and an upper member formed almost entirely of shale. The Kennicott formation is in large part a conglomerate, but includes limestone, sandstone, and shale beds. Its age is Upper Jurassic or Lower Cretaceous and its deposition was separated from that of the Triassic shales by a long erosion interval, so that in some places it is found to lie unconformably on the greenstone, in other places on the limestone or on the limestone and shales. In addition to the sedimentary rocks that have been mentioned, there is in the western part of the district an area of limestones, shales, and conglomerates with associated sills or flows of basalt of unknown age that has not been correlated with any of the four first-named formations, and there are also in the eastern part of the district at least two areas of coal-bearing rocks that are perhaps younger than any of the four major formations.

The igneous rocks, in part extrusive and in part intrusive, are represented by both basic and acidic types. A list of these includes gabbro, diabase, diorite, andesite, granite, and rhyolite. Surface flows, mostly andesite, and fragmental volcanic deposits, chiefly rhyolite, cover relatively large areas in the western part of the district and higher parts of the Wrangell and Skolai mountains. Surface flows of diabasic character that have been covered by younger sedimentary deposits have their most important representative in the Nikolai greenstone previously mentioned. Intruded porphyritic dikes related 
to the diorites are very abundant in places, particularly in the Triassic limestones and shales. Only one considerable mass of the lighter-colored granitic intrusives, however, is represented on the map, and gabbro, so far as is now known, is restricted to 3 localities.

The principal unconsolidated deposits of the region comprise sands and gravels deposited in water and the more poorly sorted or unsorted fragmental material resulting from glacial activity. They are most extensive in the broad lowland bordering Chitina and Nizina rivers, but are well developed in most of the tributary valleys:

The geologic map (Pl. II) shows the general distribution and areal relations of the rocks that have been briefly described. It is given in practically the same form as when first published in 1901, but a few changes have been made, particularly in the vicinity of Elliott Creek. Furthermore, the representation of the Chitistone limestone in the southeastern part of the area has been omitted. This region was not visited in 1907 and was seen only from a distance by geologists of the Survey party in 1900. Prospectors report that limestones outcropping near the Chitina on its north side above Tana River are not part of the Chitistone limestone. That the identification of this limestone was doubtful was also suggested in the original report, and it has therefore seemed best to omit it on the accompanying geologic map. One other change of less importance has been made in mapping the vicinity of Hidden Creek west of Kennicott Glacier.

The detailed geologic descriptions which follow are quoted almost entirely from the published report of Schrader and Spencer. ${ }^{a}$ Sich portions of that paper as deal with areas outside the limits of the area here under discussion are omitted. A few explanatory words are inserted in brackets. Some new material is introduced, and a few changes are made where later work has shown the earlier conclusions to be inaccurate. The most important change appears in the substitution of Chitistone for Carboniferous in those places where Carboniferous was used to indicate the massive Triassic limestone. The error arose from a lack of fossil evidence with which to determine the age of the Chitistone limestone and from an attempt to correlate it on stratigraphic and lithologic grounds with the massive "Upper Carboniferous" limestone at the head of White River. It has been necessary on account of the substitution to change the original wording slightly in one or two places, in order that there may be no mistake concerning the age of the limestone and that the close relation between the Chitistone limestone and Triassic limestones and shales may appear.

${ }^{a}$ Schrader, F. C., and Spencer, A. C., The geology and mineral resources of a portion of the Copper River district, Alaska, a special publication of the United States Geologicai Survey, 1901, pp. 40-62. 
The account of the unconsolidated Pleistocene and Recent deposits is entirely rewritten in such a way that the general discussion of these deposits as occurring in the Copper River Valley is not taken up.

\section{UNDETERMINED ROCKS ON KOTSINA RIVER. $a$}

On either side of Kotsina River and extending from the edge of the andesite west of Long Glacier and the region about Clear Creek southward to lilliott Creek there is a series of rocks whose relations and age have not been determined. 'They are made up of sediments, jncluding limestones, shales, and coarse conglomerates, with intercalated sheets or flows of basalt like the Nikolat greenstone. The pebbles of the conglomerate are composed of greenstone material.

The series shows a general dip toward the southwest, and in this regard it follows the structure of the Nikolai greenstone and the Chitistone limestone which occur farther up the river. The age of the series is unknown, but from the structure it would seem that it must be younger than the Chitistone, which appears to dip beneath it. Owing to its make-up, however, and the fact that it has been affected to a certain extent by metamorphism, it seems impossible to correlate it with the adjacent Triassic strata. If, however, it is older than the limestone, it may be representative of a series equivalent to the Orca rocks occurring in Prince William Sound. This suggestion is made in the most tentative way, since there is no evidence at hand for the determination of the stratigraphic position of the series. For this reason it has been represented on the map as unknown sediments.

In cross section C-D [P]. II] a fault is suggested to explain the relation of the rocks shown on the map in the region of Copper and Pass creeks. The existence of such a fault would also explain the occurrence of the unknown series in its observed relations, on the supposition that it belongs beneath the mass of the Nikolai greenstone.

\section{NIKOLAI GREENSTONE. $b$}

Description.-The term "Nikolai greenstone" is employed to designate a series of volcanic flows forming an important mass in the Wrangell district. The rock shows considerable variation from place to place, both laterally and vertically, in the separate flows. In color it is generally green, though in some places it is of a reddish hue. In texture it varies from fine-grained, very densely crystalline, to rather coarse-grained porphyritic, and in many places it shows amygdaloidal characters. Under the microscope the rock is found to consist of feldspar and augite, with considerable quantities of two green minerals, which are found to be chlorite and serpentine. In rare instances grains of olivine are noted under such conditions that it seems certain that the serpentine had its origin in the alteration of the olivine. The structure is always that which is characteristic of diabase, where the laths of feldspar form a feltlike mesh with augite lying in the interstices. At times the rock is so fine grained that it hecomes almost aphanitic, while at other times the crystals of feldspar have dimensions reaching several millimeters. Wheu amygdaloidal, as it frequently

\footnotetext{
"Schrader and Spencer, op. cit. .

${ }^{b}$ Greenstone is a word sometimes used in an indefinite noncommittal way to designate altered igneous rocks that may differ much in other ways but possess the common characteristic of green color. The term "greenstone" is perhaps most frequently applied to certain metamorphosed diabases or diabase tuffs, but is also used in connection with altered diorites and gabbros.
} 
is, the cavities are filled by chlorite or serpentine, either with or without chalcedonic quartz. Accessory magnetite is always present and frequently in considerable amounts; also in many cases metallic sulphides are present, though these are probably of secondary origin. Locally metallic copper occurs in grains or stringers, but always under such circumstances that it may be considered of secondary rather than primary origin. The composition and structure of the Nikolai greenstones show them to have been originally typical basalts. * * *

Occurrence and distribution.-The Nilsolai greenstone occurs in many places in the Wrangell and Skolai mountains and wherever seen is found to show the same relations to the sedimentary series of the region. The massiye Chitistone limestone, which is the lowest unmetamorphosed sedimentary formation of the district, lies directly upon the greenstone in such a way that it would seem as if it had been originally laid down upon the surface of the earlier volcanic flows. In this relation it is observed in the upper part of Kotsina River, where the greenstone passes beneath the Chitistone limestone, dipping toward the southwest, and forms a large part of the mountain masses that are drained by the southern glaciers of the Kotsina basin. From this region it connects directly with the occurrence in the mountains in the vicinity of Kuskulana Glacier, and, reappearing in the valley of the Lakina, is again found in the upper part of the Kennicott drainage, whence it may be traced (always bearing the same relation to the massive limestone) across McCarthy Creek and thence to the Nizina and the mountains to the east. [See Pl. III, A.]

The thickness of the greenstone flows is not known, for while the top is easily determined the bottom has not been recognized with certainty. In the upper Kotsina basin the Nikolai greenstone as represented on the map' includes some tuffaceous beds, hard, gray, siliceous or silicified beds (perhaps tuffaceous also), cherty beds which are possibly a variation of the siliceous beds last mentioned, and even some dark-gray or black slates. It is probable that on closer study the Nikolai greenstone may be divided and the word greenstone applied to only a part of the succession in such a way as to more nearly conform with the stricter use of the term. ${ }^{a}$ The Nikolai greenstone as it is mapped probably has its greatest thickness in the upper Kotsina country, where it was estimated by Schrader and Spencer as roughly 4,000 feet thick.

Structure of the greenstone. ${ }^{b}$-From the origin of the greenstone series, through the successive outflow of innumerable sheets of basalt, it is natural that the complex should show a bedded character comparable to stratification in sedimentary rocks, and in many places this structure is very well exhibited. The bedding in the volcanic series is always found to be in accord with the structure of the overlying water-laid formations.

Locally the greenstone shows a secondary structure due to shearing [as illustrated in Pl. III, B], which is reproduced from a photograph taken below Surprise Creek on Kotsina River. ***

. Age of the greenstone.-Concerning the actual age of the Nikolai series little can be said. They are older than the Chitistone limestones which rest upon

\footnotetext{
a The possibility of correlating part of the Nikolai greenstone succession with some of the interbedded Carboniferous shales, tuffs, and lava flows examined in 1908 in the region about Skolai Pass and the head of White River is suggested.

$\checkmark$ Schrader and Spencer, op cit.
} 


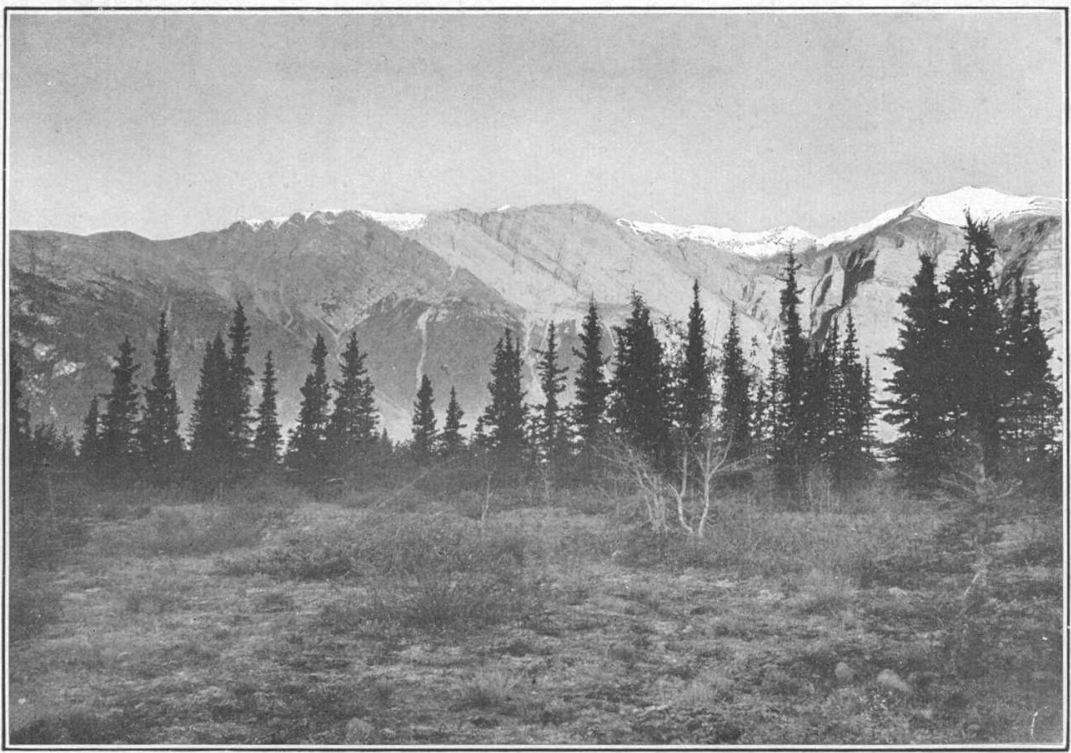

A. CONTACT OF NIKOLAI GREENSTONE AND CHITISTONE LIMESTONE, WEST OF NIZINA RIVER, NEAR NIKOLAI MINE.

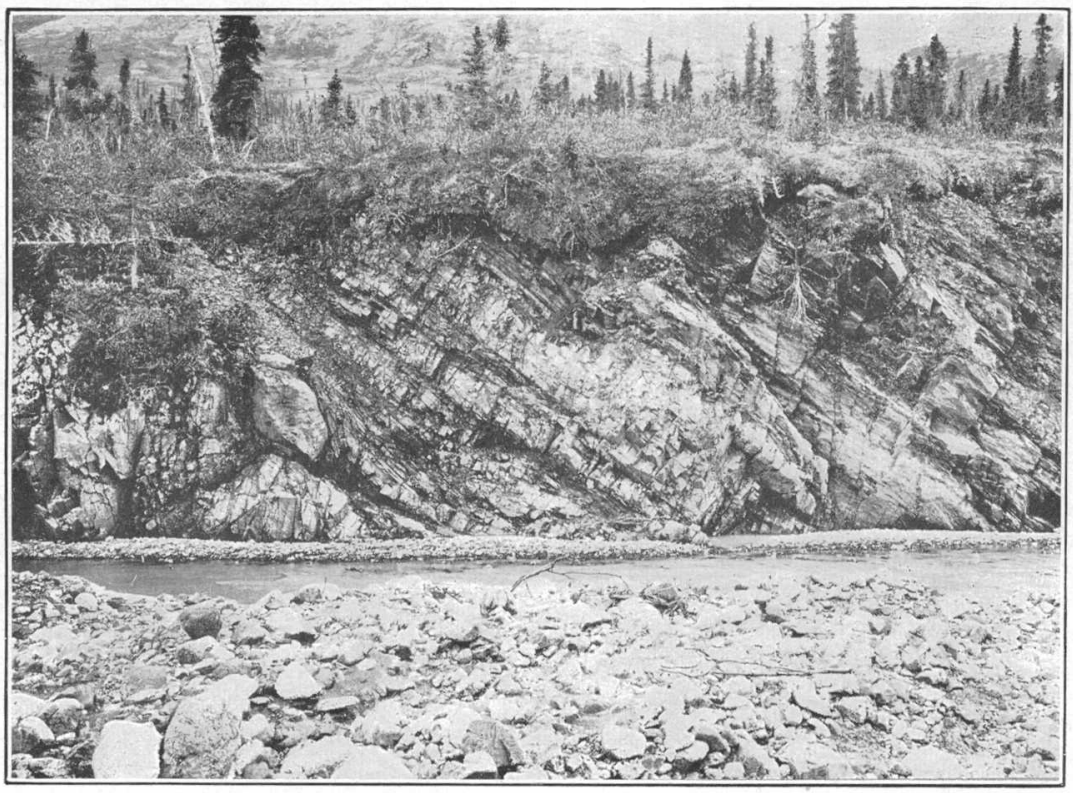

B. SHEARED GREENSTONE ON SOUTH SIDE OF KOTSINA RIVER, BELOW SURPRISE CREEK. 
them, though probably not very much older, since there seems to be no folding in the interval between the close of the volcanic ontflows and the beginning of marine sedimentation. $* * ;$

The evidence that the greenstone was formed previous to the Chitistone limestone is as follows: Wherever the two are in contact the limestone shows no metamorphism, such as usually results from the intrusion of a calcareous rock by an igneous mass; the pseudostratification in the greenstone is parallel with the bedding of the overlying limestone wherever observed, and the layers in the former are different in structure and general appearance. These facts, and the frequent occurrence of amygdaloidal phases in the greenstone and extremely marked variations in the coarseness of crystallization within short distances, are distinctly in favor of the origin of the greenstone by successive flows of basalt at a date preceding the deposition of the limestone. Furthermore, there are no dikes or irregular intrusions of the basalt which can be definitely shown to cut across the Triassic strata, a condition which could hardly exist if the greenstone had been forced into the sedimentary rocks in the form of a long laccolith at a constant horizon. " " "

\section{CHITISTONE LIMESTONE [TRIASSIC].}

Description.-The Chitistone formation is composed of very massive limestones, without any important intercalations of shale. When weathered, it has a white or gray color, which makes it prominent in contrast with the greenstone upon which it lies, but when broken it is found to have a blue color, which is indicative of considerable carbonaceous material in its composition. In texture it is fine-grained throughout.

Occurrence and distribution.-The massive Chitistone limestone is one of the most prominent formations of the Wrangell region. It is found lying above the greenstone in the upper part of the Kotsina basin, where it crosses the river at the mouth of Kluvesna Creek. Northwest of this place it has been traced as far as Long Glacier, which comes down from the slopes of Mount Wrangell, but beyond this glacier it is hidden by recent flows of andesite. Sontheast of the Kotsina the limestone is found at various localities, which can not be connected upon the surface, since there are overlying unconformable cleposits on the higher mountains, but the main outcrop may be traced toward the sontheast to the divide between Rock Creek and the Kuskulana, and thence in the mountains which lie between Strelna Creek and Kuskulana River the formation is prominent. It is thought that the limestone may also occur on the southwestern slopes of the mountains beyond where the Kuskulana comes out into the open basin of the Chitina Valley, but no observations have been made on this vicinity. At a point a mile or so above Trail Gulch, on the east side of Kuskulana River, the limestone appears, and, rising rapidly above the massive Nikolai greenstone, soon reaches the tops of the mountains lying south of Kuskulana Glacier. East of the first prominent creek on the south side of the eastern fork of Kuskulana Glacier observations have not been made, but from the distant view obtained of the upper part of the drainage it seems that the massive limestone is not present. Its absence must be explained through folding or faulting, the nature of which could not be ascertained. The limestone appears again on the east side of Lakina River above the lower end of the glacier, where it rises rapidly toward the northeast, and while probably it connects directly with the exposure on the west side of the Kennicott drainage it has not been so represented on the map because of the lack of sufticient observations. On the east side of the mountains between Lakina and Kenni- 
cott glaciers the limestone is very well exposed, and dipping slightly toward the north appears in the mountain between the first forks of the glacier, and igain across the eastern fork about 7 miles above the foot of the glacier. From this place the massive stratum can be traced across McCarthy Creek to the head of Nikolai Creek and to Nizina River. In the region between Kotsina River and the Lakina the general dip of the formation is southward, but from the Kennicott to the Nizina the structure is in the opposite direction, the dips varying from $20^{\circ}$ to $60^{\circ}$. This structure is indicative of an anticlinal axis having a general northwest-sontheast direction.

East of Nizina River the structure is more complex, and while the dips are not so steep the simple anticlinal structure gives place to a series of broad folds at times showing quaquaversal dips, so that erosion has revenled the underlying greenstone at various places both along the Nizina and on the tributaries which join it from the east. A view of the drainage basin of Skolai Creek shows the limestone rising gradually toward the White River divide, with greenstone lying in the valleys. At the mouth of Chitistone River the limestone comes to the valley bottom on the north side, while on the south it is from 1,000 to 1,500 feet higher, and between the forks the greenstone reaches to the top of the mountain. From the lower side of the Chitistone the formation may be traced along the side of the mountain until the upper part of the creek [Dan Creek] which joins the Nizina at Nikolai House is reached, where the rocks are seen to be descending. [The character of the contact between the limestone and the underlying volcanic series is illustrated in Pl. III, A, which also exhibits some of the structural features that have been mentioned.]

Southward from the stream [Dan 'Creek] which joins the Nizina at Nikolai House the limestone is not found, and it seems necessary to suppose that its absence is due to a fault which follows the general course of this tributary. The mountains to the south are composed of •black shales intruded by igneous dikes, and are supposed to belong to the Triassic series lying west of the Nizina. The same series is found south of the belt of greenstone without the occurrence of the limestone between, so that it seems probable that the supposed fault extends toward the west at least as far as Lakina River. The general line of the displacement has been represented on the geological map. * * *

I'hickness of Chitistone limestone.-Studies of the [Chitistone limestone] and [the other] Triassic strata of the Wrangell district have not been - sufficiently detailed to afford evidence as to where the line between these two formations should be drawn. Above the massive basal series of limestones there is a series of thin-bedded limestones with shaly partings which is apparently in perfect conformity with the underlying beds and which passes by gradation into the black shales above. These black shales contain the fossils by means of which the Triassic age of the formation has been determined. The provisional and arbitrary line between the two formations has been placed at the top of the massive limestone series. The thickness of the Chitistone formation, as thus defined, is somewhat variable. Its maximum development is probably in the region of Nizina River, where it reaches a thickness of approximately 2,000 feet. In the Kotsina and Strelna region its thickness is somewhat less, but it can not be made out that there is any progressive thinning toward the west.

Age of the limestone.-There has been doubt concerning the age of the. Chitistone limestone, owing to the fact that no determinable fossils were collected from it until the summer of 1907. Schrader 
and Spencer correlated the Chitistone with the massive limestone near the head of White River on Kletsan Creek, described by Brooks."

Schuchert, who determined the fossils collected by Brooks, states: "These two localities are of one general horizon in the Upper Carboniferous. $* * *$ I have made no specific determinations, since the fauna is not to be correlated with that of the Upper Carboniferons of the Mississippi Valley, but with the Fusulina zone of China, India, and the eastern slopes of the Urals." At a later date, however, Schuchert assigned the White River rocks to the Permian. ${ }^{b}$

Mendenhall, on the assumption that the Chitistone had been correctly correlated with the limestone at the head of White River, accepts provisionally the Permian age of the Chitistone. He evidently felt that the correlation was a doubtful one, however, and sums up the evidence for and against the Permian age of the Chitistone limestone as follows:

For Permian age :

1. The Chitistone is geographically very near and lithologically very similar to the Fermian north of Skolai lass.

2. It lies beneath known 'Triassic.

3. There is no similar heavy limestone in the known Triassic. Against Permian age:

1. The Chitistone heavy limestone and the thinner beds above it are nonfossiliferous, while the Permian in other localities is very fossiliferous.

2. The Chitistone seems to lie conformably below known Triassic, while the known Permian lies unconformably below Triassic when the relations are shown.

3. The Chitistone is free or nearly free from basic intrusives and overlies basic effusives, while the known Permian near by is extensively intruded by basic masses.

In 1907 fossils were collected from the Chitistone limestone at a number of localities between Kotsina River and Chitistone River, and they definitely determine its age as Triassic. Part of these fossils were found in place, but a majority were collected from the talus débris below cliffs of the limestone, yet there was no place where it seemed possible that the limestone fragments containing the fossils could have come from any other source than the cliffs above them. and no hesitation is felt in accepting their evidence for the age of the Chitistone. The fossils were determined by T. W. Stanton, who describes them as follows:

Several different localities are represented in the collections, but the fossils. with one exception, are all said to be from the Chitistone limestone and closely associated formations. The collection is small and somewhat fragmentary, but

\footnotetext{
a Brooks, Alfred H., A reconnaissance from Pyramid Harbor to Eagle City, Alaska: Twenty-first Ann. Rept. U. S. Geol. Survey, pt. 2, 1900, p. 359.

${ }^{b}$ Mendenhall, W. C., Geology of the central Copper River region, Alaska: Prof. Paper U. S. Geol. Survey No. 41, 1905, p. 43. On the other hand George F. Girty believes that all the sedimentary beds of Alaska that have been described as Permian are "Upper Carbon. iferous."

Op. cit., p. 51.
} 
it has proved sufficient to show quite conclusively that the beds in question are of Triassic age. The ammonites, especially, are all characteristic Triassic types, and the few brachiopods obtained are also Mesozoic. There is no indication of Paleozoic fossils in any part of the section represented.

The single ammonite from Chititu Creek is of more modern types and most probably comes from the Jurassic.

The following lists give the forms recognized from each locality. In most cases specific identifications have not been possible, but this does not lessen the accuracy of the age determination.

4S04. No. 1. Elliott Creek, from beds above Chitistone limestone. Pseudomonotis subcircularis (Gabb). A single imperfect specimen of this Triassic: species.

4805. Nos. 2 and 23. Hoodoo or Mullen claim on Copper Creek, Kotsina River. Chitistone limestone. Hinnites? sp. Undeterminable cross section of ammonites.

4805. Nos. 3 to 6 . Chitistone limestone. Talus on Copper Creek. Terebratula sp., Spiriferina sp., Hinnites? sp., Pleuromya? sp.

4S06. No. 7. Crawford's Skyscraper claim on Roaring Creek, Kotsina River, Chitistone limestone. Natica? sp. Undetermined bivalve fragments.

4808. Nos 9, 14 to 19, 21, 22. Bonanza mine and Bonanza Creek. Undetermined corals. Terebratula sp., Spiriferina sp., Hinnites? sp., Pseudomonotis subcircularis (Gabb)?

4809. Nos. 10 to 13, 20. Jumbo Creek near the Bonanza mine. Pentacrinus sp., Terebratula sp., Avicula? sp., Arcestes? sp. (cross section), Juvavites? sp. The last two named are certainly Triassic types of ammonites and probably belong to the genera to which they are provisionally assigned.

4810. Nós. 24, 25. South side of Chitistone River at Houghton-Alaska Company's prospect. Spiriferina? sp., Halobia sp., Arcestes? sp., Tropites? sp. The last two are Triassic ammonites provisionally identified from imperfect specimens.

4811. No. 26. Chititu Creek. Perisphinectes? sp. This ammonite is not a typical Perisphinectes, but it is probably of Jurassic age-certainly not older than Jurassic.

\section{TRIASSIC LIMESTONES AND SHALES.}

Description ${ }^{a}$-The rocks which have been included in the Triassic [limestones and shales] series comprise all the strata that lie above the Chitistone limestone and below the unconformable Kennicott formation of Jura-Cretaceous age. In the lower part, and resting conformably upon the Chitistone limestone, is a series of thin-bedded limestones, in strata from a few inches to a foot or moie in thickness, supported by thin partings of black shale (Pl. IV, A ). The thickness of this member is approximately 1,000 feet, and the limestone, so far as observed, did not contain fossil remains. Above the thin-bedded limestones, and sharply defined from them, are black shales containing occasional bands of impure limestone, locally affording fossils, from which the age of the formation has been determined. The thickness of the upper member of the Triassic is very great, possibly more than 3,000 feet, but no opportunity was offered for its direct measurement, since its occurrence beneath strata lying unconformably upon it, together with the attitude which it has assumed as the result of folding and faulting, renders its relations complicated and obscure. A few thin flows of greenstone, similar to that of the Nikolai series; were observed here and there interbedded with the black shales of the Triassic. The 


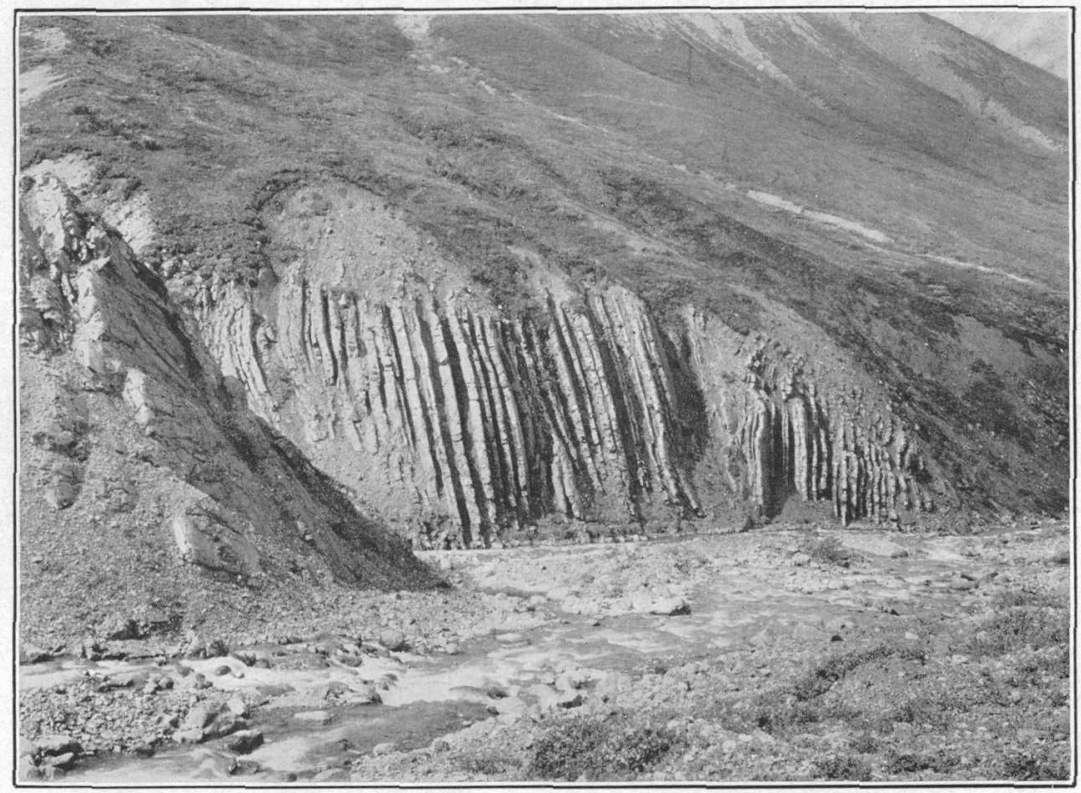

A. THIN-BEDDED TRIASSIC LIMESTONE AND SHALE ON WEST BRANCH OF ROCK CREEK.

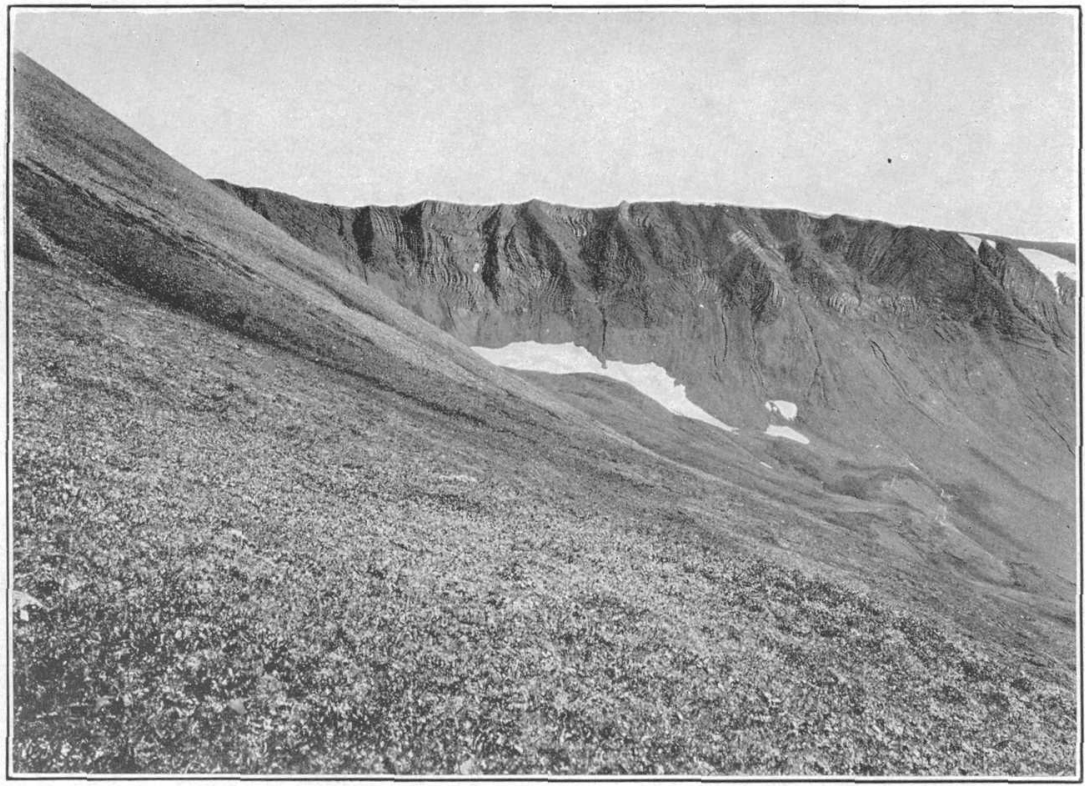

B. CRUMPLING IN THIN-BEDDED TRIASSIC LIMESTONE ON RIDGE EAST OF GILAHINA CREEK. 
'Triassic [limestones aud shajes] series may be ensily recognized from its general homogeneous nature and the fine-grained character of its black carbonaceous shales.

Locally the thin-bedded limestones are very intricately folded and contorted, a feature which is well shown in the ridge formed of Triassic rocks at the head of Gilahina Creek [and is illustrated in Pl. IV, B].

Occurrence and distribution.-The Triassic rocks [limestones and shales] are found dipping toward the southwest in the Kotsina region, and may be traced in a continuous band southwestward [southeastward] to Kuskulana River and from the east side of that stream to Lakina River and thence to the Kennicott and Nizina. East of the Nizina they occur principally in the region south of the great fault which limits the Chitistone limestone, and in the region south of the Nizina the black shales reach across Chitina and Tana rivers and come in contact with rocks of the Valdez " series." Their occurrence in the vicinity of Skolai Pass is reported by Hayes. "* * *

In the region sonth of the fault and east of Lakina River and again east of this region as far as the mountains beyond the Nizina the Triassic shales are rery intricately intruded by dikes and sheets of porpbyry.

f'ossils of 'I'riassic bcils.-Only two recognizable fossil forms have been determined in the material which was collected from the Triassic beds, but these are considered sufficient to fix definitely the age of the series. 'T. W. Stanton, of the Geological Survey, reports the following forms of Upper 'Triassic age: Monotis subcircularis Gabb and Daonella like D. lommeli Wissmann.

\section{DISTURBANCES FOLLOWING DEPOSITION OF TRIASSIC.}

The formations next younger than the Triassic shales in the Copper River region were deposited at the close of the Jurassic or the beginning of the Cretaceous-that is, at a time corresponding to the deposition of the Knoxville beds of the northwestern United States. 'These latter rocks are unconformable upon the Triassic and older formations and previous to their formation the older rocks had been folded and raised above the sea and their upturned edges reduced by the process of erosion. The close of Triassic deposition in the western and southwestern portions of the continent has been very generally recognized as a period of mountain building and of geological revolution. It is supposed by Dawson that at this period the Vancouver and coast ranges of Biitish Columbia were outlined, and that there was probably at the same time some corrugation along the line of the Rocky Mountains. ${ }^{b}$ The result of this disturbance in the Wrangell district was the production of the broad folds which have been recognized from the attitude of the Nikolai greenstone and the overlying sediments. The period of erosion which followed the uplift and

a The term Valdez "series" was first used by Schrader in a report entitled "A reconnaissance of a part of Prince William Sound and the Copper River district, $\Lambda$ laska, in 1898" ('Twentieth Ann. Rept. U. S. Geol. Survey, pt. 7, 1900, p. 408) to describe the l'ocks typically developed in the vicinty of Valdez. The Valdez "series" includes a succession of highly metamorphosed sedimentary beds and consists of "bluish-gray and dark quartzites, arkoses, and quartz schists, interbedded with generally thin beds of dark blue or black slate, shale, mica schist (in some places highly graphitic), nodular mica schist, and occasionally some stretched conglomerate." So far as is now known the Valdez "serles" makes up the greater part of the Chugach Mountains. Its rocks are exposed along Copper River from the vicinity of Wood Canyon at least as far south as Baird Glacier. It is not known how far eastward they extend.

${ }^{\circ}$ Dawson, George M., On the late physiographic geology of the Rocky Mountain region in Canada, with special reference to changes in elevation and to the bistory of the glacial period: Trans. Roy. Soc. Canada, vol. 8, 1890, sec. 4, p. 6 . 
folding was a very long one, since the amount of rock removed must necessarily have been measured by several thousand feet.

The general trend of the fohts in the Triassic rocks is parallel with the structure of the adjacent Valdez "series.". This older structure is very uniform throughout the whole region from the coast to Copper River, and it is only natural that the recurrence of dynamic action in the region should have produced structures in accord with the lines of weakness that were developed at a very early date.

The Nikolai greenstone and the sedimentary formation which lie conformably above it are at present found to be considerably jointed and cut by fissures. It is probable that this fracturing of the rocks was produced during the post'Triassic disturbance, though it is reasonable to suppose that subsequent movements, which must have accompanied the volcanic phenomena of the region, may have caused additional fracturing and folding of the rocks.

It is believed that the eruptive phenomena of the Wrangell region may have begun during this period of disturbance, but there is no evidence to show that the intrusion of the Triassic shales occurred at this period rather than at a much later date, when, as is known, volcanic forces were very active.

\section{KENNICOTT FORMATION.}

Description.-The strata which, on the evidence of fossils, have been assigned to the Upper Jurassic or Lower Cretaceous consist of a variable series of conglomerates, sandstones, limestones, and shales. The formation lies unconformably upon the upturned edges of the older rocks, resting in different places upon the Nikolai greenstone, the Chitistone limestone, and the shales of the Triassic. In places it appears that these older formations were completely leveled by erosion previous to the deposition of the Kenuicott formation, but elsewhere the relations, though obscure, are indicative of the probability that deposition took place in narrow, deep lagoons.

At the base of the formation there is usually a conglomerate or coarse sandstone composed of materials derived from the greenstone and from the limestones and shales, with an admixture of quartz sand. Above this there are alternations of greeu sandstone with black shales, and occasionally bands of limestoue, in places containing considerable sand.

Occurrence and distribution.-The northermmost known occurrence of the Kennicott formation is at the head of Limestone Creek between Clear and Kluvesna creeks. Here the formation is in contact with the Chitistone limestone and with the Triassic shales. South of this there is an outlier resting upon the shales, forming the top of a high peak between Clear Creek and Kluvesna Creek north of Kotsina River. South of the Kotsina the formation is found usually capping the highest ridges, where it rests upon the Triassic [shales and limestones] or locally upon the Chitistone or the still older greenstone. From the ridge between Sheep and Copper creeks there is considerable cropping of the formation, which extends continuously to the divide between Rock and Strelna creeks, and again there is a considerable thickness in the high mountains at the head of the south fork of Strelna Creek.

As viewed from a distance the high ridge between the north fork of Kuskulana Glacier and the eastern drainage of the Kotsina appears to have a capping of sedimentary rock resting upon the greeustone, and though this region has not been visited it seems probable that the Kennicott formation may occur in these high peaks. To the east of the Kuskulana Glacier it first appears in the bed of 'Trail Gulch, at an elevation of about 2,200 feet, and may be traced eastward for a distance of about 3 miles. In this locality the formation affords 


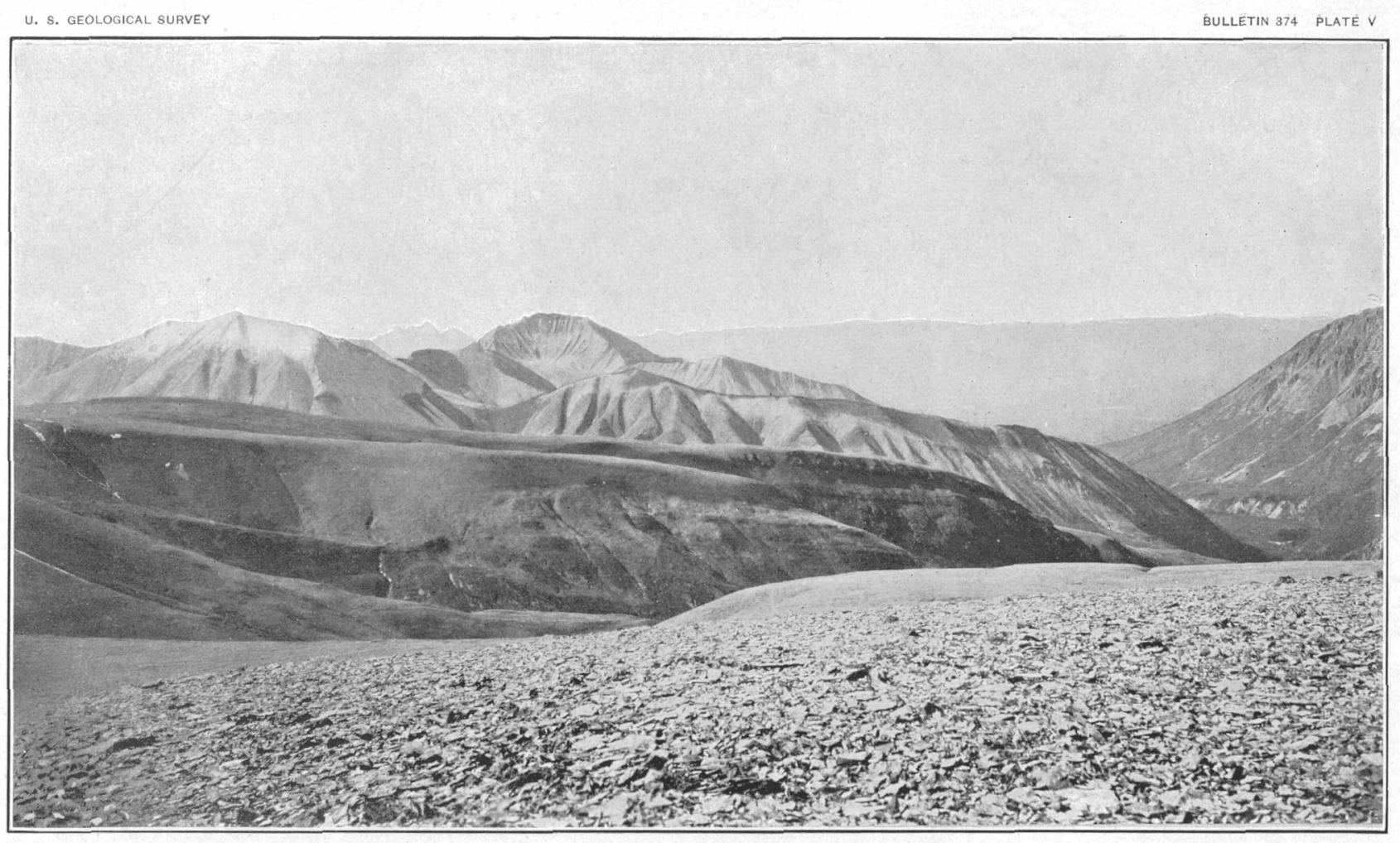

HEAD OF NIKOLAI CREEK.

Base of Kennicott formation in foreground; Chugach Mountains in background. 
fossil remains. It does not appear again west of Lakina River, but to the east of that stream, in the drainage of Fohlin Creek, it attains considerable development, having a thickness which possibly reaches 1,000 feet or more. In this locality and in the last it seems as if the formation was deposited in a submerged valley, the sides of which had considerable height above the level of the water.

East of Kennicott River the Kennicott formation occurs at the head of Nikolai Creek, where its general relations to the topography and to the Triassic formations are shown in Pl. [V]. The sloping stratit in the middle of the illustration are the sandstones of the basal portion of the Kennicott formation, while the deep trenches cut through them into the underlying limestone and greenstone. The mountains in the distance are composed of Triassic shales, with igneous intrusions, which have protected the mountains from erosion.

Beyond the Nizina the formation is found capping the shale ridge between Young Creek and the Chitina.

Age of Kennicott formation.-The age of the Kennicott formation has been definitely determined by Dr. 'T. W. Stanton, who has studied its fossils and proved their general correspondence with the fossils of the Knoxville formation of northwestern United States. This places the formation in the doubtful series lying at the top of the Jurassic or at the base of the Cretaceous. 'The following forms have been recognized :

Inoceramus eximius Jichwald?

Aucella pallasi Keyserling?

Belemnites sp.

Halobia occidentalis Whiteaves?

Rhynchonella sp.

Pecten sp.

Avicula sp.

Lytoceras sp.

Hoplites sp.

Olcostephanus? sp.

Gryphiea sp.

Sagenopteris sp.

Concerning Inoceramus eximius Doctor Stanton says:

"This form is represented by a single specimen collected on Chitty" Creek. It may be distinct from Eichwald's species, originally described from Turkusitun Bay in Cook Inlet and referred by him to the Neocomian. Eichwald described three other species-I. ambiguts, I. porrectus, and $I$. lucifer-all belonging to one section of Inoceramus, from the same horizon in Alaska. The present shell does not agree perfectly with any of the figures, but it is most nearly like I. cximins and probably comes from the same formation. Similar forms occur both in the Jurassic and in the Cretaceous, but the evidence of the other fossils from this part of Alaska favors the reference of the Kennicott formation to the Jurassic."

Of the form referred with a question to Halovia occidentalis, Doctor Stanton says:

"The specimens agree fairly well in sculpture and general appearance with some of the figures of Whiteaves's species from the Liard River, and may be identical with it. They are, however, somewhat suggestive of Hinnites linconsis, from the Jurassic (?) of Siberia.

"Sugenopteris is a genus which occurs both in the Jurassic and in the Cretaceous, but the species is thought by Professor Ward, to whom it was shown, to be near a species occurring in the Jurassic of the Pacific coast."

Concerning the general relations of the fossils from the Kennicott formation Dr. Stanton observes:

"These fossils are all either Upper Jurassic or Cretaceous, with a suggestion of a somewhat younger age for a few localities. In the present state of: knowledge, and with these small collections, it is not practicable to determine whether they represent one horizon or several. In my opinion, they probably 
all belong to the Upper Jurassic, though subsequent work may show the contrary. The question is connected with the still unsolved problem of the exact boundary between the Jurassic and the Cretaceous in the Aucella-bearing beds of Russia, Siberia, and the Pacific coast region of North America. The Aucella occurring in the Copper River district appears to be referable to a Russian 'Jurassic species, but it is also quite similar to the Cretaceous form in the lower Knoxville beds of California. The few other forms are mostly undescribed species of types that occur both in the Jurassic and in the Lower Cretaceous."

\section{POST-KENNICOTT DISTURBANCE AND EROSION.}

After the deposition of the Kennicott formation the region seems to have been uplifted from its previous low position with reference to the sea and to have suffered a slight deformation, which gave rise in great part to the present slightly inclined attitude of the rocks that were deposited not long before its initiation. In respect to the amount of folding produced this uplift was of much less importance than the earlier disturbance which caused the folding of the Triassic formations. It seems to have been a regional uplift without very much of the deformation which comes from lateral pressure.

The uplift which followed the deposition of early Cretaceous time seems to have been regional in its extent, and may be supposed to have affected all of the area between the present Wrangell Mountains and the coast and to have raised a large continent from the waters of the sea. The limits of the uplift can not be determined, but it was followed by a period of erosion during which the streams that developed upon the new land surface were able to reduce the land very nearly to sea level.

Before the completion of this cycle of erosion a period of volcanic activity was commenced which very materially altered the character of the topography by the upbuilding of immense piles of lava and of volcanic tuffs.

\section{COAL-BEARING ROCKS.}

Two localities where coal-bearing rocks are known to be present lie within the area under discussion. One is situated on the high ridge between Hidden Creek and the heads of Bear and Fourth of July creeks, the other is near the head of Chitistone River. Little is known about either locality, and there is no evidence at hand on which a definite statement concerning the age of the beds may be based. The first-mentioned locality is approximately 2 miles north of the saddle known as Fourth of July Pass, through which the trail runs in crossing the ridge between Fohlin Creek and Kennicott Glacier. The area is small, possibly not over 20 acres, and lies at an altitude of nearly 6,000 feet. The beds are probably not much over 50 feet thick, and consist of black carbonaceous shales with thin coal seams overlain by arkose sandstone. The coal beds have a horizontal position and lie unconformably on the upturned edges of beds belonging to the Triassic limestones and shales. They adjoin the Chitistone limestone on the north and appear to pass over the great fault by which the Nikolai greenstone and the Triassic limestones and shales are brought in contact. A mass of andesite, with a spirelike 
form about 50 feet high, rests on the coal-bearing rocks, but since its age is unknown it furnishes little additional evidence for the age of the coal. Coal is not known to be present in the Kennicott formation. The Kennicott, moreover, is believed to be older than the great fault, and since the coal beds, as previously stated, appear to cover the fault, it is suggested that the coal is probably Tertiary.

The Chitistone River coal-bearing beds were not seen by members of the Survey party, and their relations to the other formations are not known. From the reports of prospectors it is thought that the coal beds are thicker, more extensive, and more folded than those of the area just described, and it is possible that they may be of different age.

\section{TERTIARY VOLCANIC SERIES. $a$}

Description and occurrence.-In the region about the head of Nizina River, extending westward to Momut Blackbum and eastward into the Skolai Mountains, there is a series of bedded volcanic rocks made up of andesites, rlbyolites, and strata of pyroclastic origin. The main distribution of these rocks is in the region which was not penetrated during the explorations of 1900 , but a sufficiently extended view of the upper basin of the Nizina was obtained to indicate the relations which the series bears to the older sedimentary and igneous rocks. The character of the materials is shown by the débris occurring upon Nizina Glacier. A single outlier, which is undoubtedly to be correlated with the series, lies north of the trail opposite the pass east of Kuskulana River.

Standing upon the high, shaly ridge between McCartly Creek and Nizina River and looking toward the north and east, one sees that the black Triassic shales, with the massive Chitistone limestone beneath them and the greenstone still underlying, are folded in broad arches or domes, and that these structures Lave been eroded to a general uniform surface, and upon this surface a series of rocks has been nonconformably deposited. Assuming, as seems allowable, that these rocks were deposited in a nearly horizontal position, it is evident that there has been some deformation since they were laid down, as there is a general dip of the stratification toward the north, so that the serles rising toward the south and east disappears where the underlying formations come up to form the tops of the range. Volcanic rocks, the description of which answers very well to that of this series, were mentioned by Rohn as occurring in the region at the head of the Nizina and the Tanana, also along the northern edge of the St. Elias Range; and an important volcanic series on Nabesna River has been described by Brooks. ${ }^{b}$

The rocks of the series are said to include rhyolite, andesite, and basaltic types. A similar series of volcanic rocks is known to occur along the northern front of the St. Elias Range.

Thickness of volcanic series.-No accurate determinations of the thickness of the volcanic series were possible, but from photographs showing its occurrence it is estimated that it can not be less than 3,000 feet in its maximum development.

\footnotetext{
a Schrader and Spencer, op. cit., pp. 51-52.

${ }^{b}$ Brooks, A. H., A reconnaissance from Pyramid Harbor to Eagle City, Alaska, including a description of the copper deposits of the upper white and Tanana rivers: Twenty-flrst Ann. Rept. U. S. Geol. Survey, pt. 2, 1900, p. 362.
}

$$
\text { 68797-Bull. 374-09-—3. }
$$


Age of volcanic series.-In the description of the topographic development of the Copper River region it will be shown that the land surface which was produced through the process of erosion previous to the formation of the volcanic series had its origin some time during the Tertiary, and with this conclusion as a basis it may be concluded that the age of the volcanic series is also Tertiary. There is, however, no criterion for determining the exact portion of the period to which its formation belongs, though it is doubtiess later than the Eocene. Brcoks shows that the volcanics of the St. Elias Range are probably of Tertiary age. ${ }^{a}$

\section{IGNEOUS ROCKS.}

Preliminary statement.-The igneous rocks of the Kotsina-Chitina area, as has been stated, include gabbro, diabase, diorite, andesite, granite, and rhyolite. They have not been studied in an exhaustive way and the following descriptions are general. The various rocks are grouped in the description according to their occurrence in the larger geological divisions of the sedimentary rocks. Areas of igneous rocks are not represented in a detailed way on the map (Pl. II). Diorite and granite are not separated from each other, but they are distinguished from gabbro.

The intruded rocks of a porphyritic nature are given a distinct color. Andesites also have a separate color, but no attempt is made to separate those of intrusive from those of extrusive character.

Granular rocks in the unmetamorphosed scdiments. ${ }^{b}$-The intruded rocks which occur in the unmetamorphosed sediments of the Wrangell region ... consist of gabbros, granites, and dioritic rocks, and in addition there is a large cross-cutting mass of andesite which forms Castle Mountain . . .

The gabbro in the Mount Wrangell district is confined, so far as known, to three small areas: One in the Kotsina region between Long Glacier and Kluvesna Glacier, another at the head of Nugget Creek north of Kuskulana River, and the third just above the forks of Strelna Creek. The rocks of these three localities belong to the same type, but show minor variations. The gabbro occurring in the vicinity of Long Glaciel is a coarse-grained rock, consisting of a very basic plagioclase, probably bytownite, and augite in large irregular grains. With the augite there is a small amount of brown hornblencle, which is probably original. Magnetite occurs in large grains. In the gabbro of Strelna Creek there is some interstitial micropegmatite which is probably of secondary origin.

A rock which is similar to these gabbros, but which has, in addition to the minerals which they contain, a considerable amount of brown mica, was noted in the vicinity of the crossing of the main Chitina and the Kotsina trails. Here, in the walls of the canyon, there is a coarse-grained granular rock made up of andesite, diallage, hypersthene, and a considerable amount of dark-brown biotite. The relations of this rock are rather unusual, since it is granular rock cutting glacial gravels.

The only granite which has been noted in the Wrangell Mountains is located somewhere in the drainage of the second Kotsina Glacier. Its presence is known only from a specimen collected from the moraine. It is a fine-grained rock composed of biotite with some plagioclase.

${ }^{a}$ Op. cit., p. 363.

- Schrader and Spencer, op. cit.; p. 55 ét seq. 


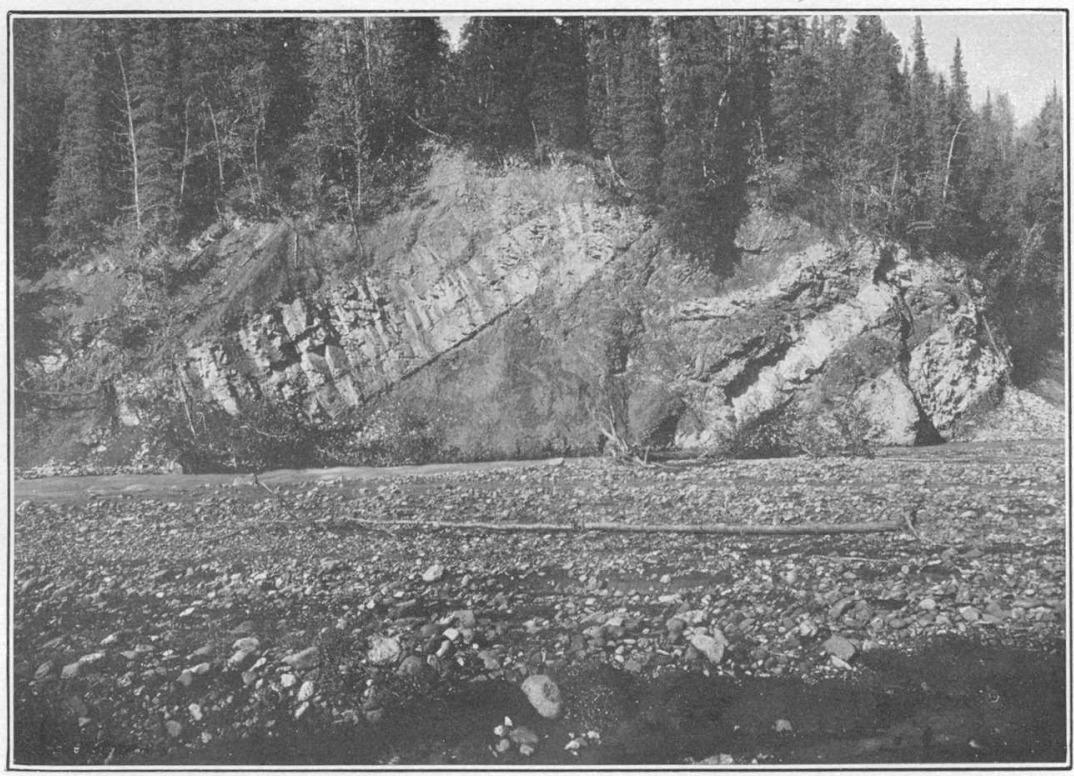

A. INTRUSIONS OF FINE-GRAINED PORPHYRY IN BLACK SHALE ON YOUNG CREEK.

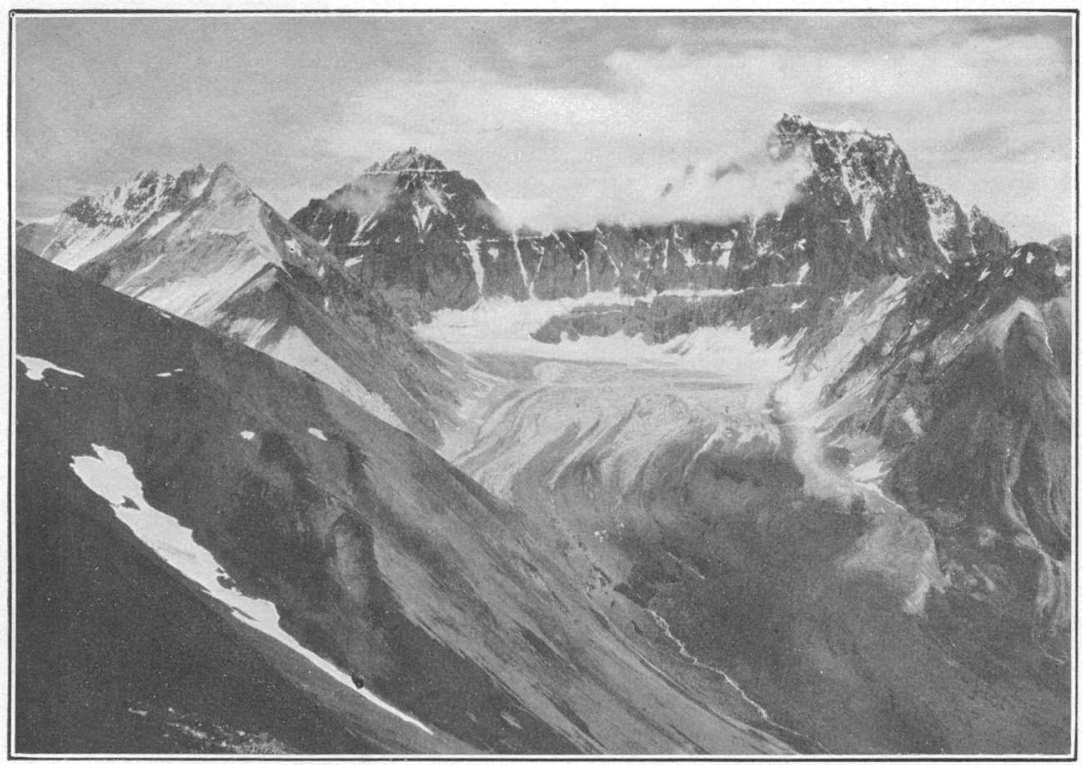

B. CASTLE MOUNTAIN.

Looking N. $60^{\circ}$ W. from ridge between Gilahina Creek and Lakina River. 
On the north side of the main ,tributary of Kotsina River, near Surprise Creek, there is a masss of diorite which varies considerably in' character from place to place. In some parts the rock is practically granular, while elsewhere it becomes porphyritic. It is composed essentially of abundant thick prisms of plagioclase, which is probably andesine, while between these prisms there is a sort of groundmass composed of orthoclase and quartz. Biotite and hornblende occur in irregular grains and imperfect prisms. The rock is related to granodiorite, but may be called a quartz diorite.

A porphyritic phase of diorite occur's along the west side of Kuskulana Glacier, below the forks, though this mass has not been represented on the map. 'I'he broad dike which is represented as crossing the mountain mass between the forks of Kuskulana Glacier is supposed to have the same character.

Porphyries in the unmetamorphosed sediments.-Besides the granular or nearly granular rocks already considered, there is a considerable variety of porphyritic rocks occurring in dikes and irregular masses in the black shales of the Triassic formation and in the shales and sandstones of the Kennicott series. These rocks are rather generally distributed from the vicinity of Kuskulana River eastward as far as our observations extended. They are well shown in the shale series on either side of Kennicott River, and it is to the resistance which the intruded rocks have presented to erosion that the mountains of this vicinity owe their preservation. Some less important occurrences are observed in the valley of Young Creek and as far toward the south as Chitina River. Pl VI $[A]$ is illustrative of dikes of fine-grained porphyry cutting the black shale in the walls of Young Creek.

On the map the intricate intrusion of the shales is represented in a diagrammatic way to indicate the character of the intrusions rather than the actual occurrence of the cross-cutting beds.

The porphyries of the class here under consideration are always much altered, so much so, indeed, that it is very difficult to determine their exact nature, but it may be seen that they are all not identical, though they are probably closely related throughout. They are mostly diorite or quartz diorite porphyries, judging from the aggregates of altered minerals which now make up their mass. They vary in grain from cryptocrystalline to porphyritic with stony groundmass.

These porphyries are, in part at least, later than the Kennicott formation, of Jura-Cretaceous age, for they are found cutting this series in the region between Lakina and Kennicott rivers, and dikes of porphyry cut the bedded volcanic series east of Kuskulana River, and in the Nizina region there are masses of unknown character cutting across the volcanic series. It appears that in general the intruded rocks have been injected at comparatively recent dates, although there are no data for determining the priority of one or the other of the different types of rock. It may be that the porphyries were intruded during the period of folding which preceded the deposition that took place in Jura-Cretaceous time, but so far as the evidence goes, it may be that they were introduced after the deposition of the lertiary volcanic rocks.

Andesite cutting the Triassic.-The mass of Castle Mountain is composed of dark andesite, similar to that which forms the surface flows of the Wrangell region. On the western side of the mountain the contact with the shales and crumpled limestones may be clearly distinguished by the contrast betweeen the dark-colored andesite and the sedimentary rocks which have been bleached and whitened throngh contact metamorphism. The appearance of Castle Mountain and the andesite contact is illustrated in [Pl. VI, B]. Looking at Castle Mountain from the southeast, one sees the contact running in a zigzag 
course down the ridge on the left side, as shown in the picture, and again, with less distinctness at the right, which is at the base of the steep cliff.

Intrusive rocks in T'ertiary volcanic series.-The occurrence of dikes of diorite porphyry in the volcanic series has already been noted, and aside from this the cnly knowledge of cross-cutting massive rocks has been gained from a distant view of the region lying east of the Nizina River, between Chitistone River and the first creek flowing into the Nizina. Above the foot of the glacier there is a mountainous mass, which shows the topographic characters that are common in the case of massive rocks, and this mass is in part surrounded by the flows and tuffs of the volcanic series. This occurrence is the only evidence of the postvolcanic date of the intrusive rocks, and it must be admitted as incomplete.

Andesite flows.-The recent lavas which occur on the southern and western slopes of Mount Wrangell are typical hypersthene andesites, composed of plagioclase, at least as basic as labradorite, much hypersthene in sharply outlined phenocrysts, and a small amount of augite. Olivine is sometimes present. 'The groundmass varies from glassy to finely crystalline. In color the andesites vary from red to gray and black, and in texture from vesicular to close-grained porphyritic.

The age of the andesite is Pleistocene and Recent. The form of Mount Wrangell is the result of successive lava flows, by which its cone has been constructed. The great sheet of andesite to the north of the Kotsinit drainage lies above the mass of the Pleistocene, but gravels are found resting upon it locally, and glacial scoring is also observed, so that at some time since the most important outflows glaciation must have been more extensive than at present.

* $*$ * * $\quad * \quad * \quad * \quad * \quad *$

Below 'Tonsina River, on the east side of the Copper, the river banks have a height of 400 to 600 feet, and here they are composed very largely of till. Here, also, andesite occurs in the upper part of the deposit, and this occurrence appear's to be the western extension of the general sheet of andesite which may be found at intervals and traced toward the east, becoming of more importance as the mountains are reached. East of the trail leading from Tonsina to the upper Chitina the andesite is of considerable importance, and here gives rise to a prominent bench, which may be traced northward to the point where it connects with the andesite already mentioned as occurring on Chetaslina River, and from this point still northward, forming a marked terrace for a distance of at least 10 miles. Wherever observed there is evidence that the andesite was poured out during the glacial epoch. The greatest thickness of the glacial deposits is below it, but in protected places it always shows surfaces which have been smoothed by ice action, and there is no considerable area of the andesite exposed that does not carry exotic bowlders upon it. Locally there is also a considerable amount of gravel resting upon the andesite. This relation may be seen on Copper River in the vicinity of Billum's, and also at the crossing on Kotsina River.

*

* * * *

*

$*$

$*$

The edge of the lava flow forming the plateau north of the point at which Kotsina River emerges from the mountains seems unquestionably to have been in contact with the side of a glacier which extended outward from the upper valley from the time of the eruption. The same conditions may be suggested along the north side of Long Glacier.

The distribution of the andesite as represented on the map is only approximate, and underneath the latest gravels the lava undoubtedly has a much greater extent than is indicated, and over much more of the area where it is represented gravels may be found above it. 
Just north of Long Glacier the thickness of the andesite is several hundred feet, while at the edge of the flow, in the neighborhood of Chetaslina River, it is less than 150 feet, and where it reaches Copper River and at the crossing of the Nikolai [Nizina] trail on Kotsina River it is less than 50 feet.

\section{FAULTS, $a$}

Displacements of the formatious occurriug in the Wrangell region are not at all infrequent, and while the faults are usually of swall inportance structurally, they are frequently followed by wineral-bearing veins. An example of this is seen in the Nikolai rein, which follows a fault having a throw of several feet. Two faults of very considerable importance have, however, been recognized where they cross Nizina River, while, from the observed relations of the various formations, a third break is supposed to exist in the Kotsina region. On the west side of Copper Creek the Chitistone limestone is found dipping toward the west and overlying the Nikolai greenstone in its normal position, while on the east side of the creek the greenstone comes in contact with 'Triassic shales; and though the relations of the former were not studied sufticiently in detail to allow the representation of the fault on the geological map, a break has been shown in the geological cross section in accordance with the hypothesis of a fault.

There is a fault crossing Nizina River about 3 miles above the mouth of Chitistone River, and, though its occurrence was noted, no opportunity was afforded for a detailed examination. This feature was observed by Hayes in 1891 and described as an over-thrust fault having a displacement of over half a mile. ${ }^{b}$ 'The representation of this fault on the geological map must be taken as only approximating the actual relations.

The most prominent fault which has been recognized is the one which limits the southern extension of the greenstone as it crosses Nizina River. Here the shales of the Triassic ạre brought against the Nikolai greenstone, and, though the actual fault plane was not observed, it is seen from the horizons which come in contact that the displacement must amount to 3,000 or even 4,000 feet. East of Nizina River the continuance of the break is not known; since the region was not visited, but toward the west it probably extends for a considerable distance, and on the east side of Kennicott Glacier the displacement must still be in excess of 3,000 feet. The fault was also observed on the west side of Kenuicott Glacier, and from this place it is probably continuous to Lakina River, where there is a displacement of several hundred feet. In age this great structural break antedates the deposition of the Kennicott formation, and its production probably belongs to the post-Triassic period of uplift and deformation.

\section{PLEISTOCENE AND RECENT DEPOSITS.}

Introduction.-Under the heading of Pleistocene and Recent deposits is given a general description of the unconsolidated deposits that now occupy the valley portions of the Chitina and Copper rivers and their tributaries as included in the area shown on the geologic map (Pl. II). The scale of this map is too small to give a detailed representation of the deposits, but their general distribution is well shown.

\footnotetext{
"Schrader and Spencer, op. cit., p. 62.

${ }^{b}$ Hayes, C. W., An expedition through the Yukon district: Nat. Geog. Mag., vol. 4, 1892, p. 141.
} 
Present features.-A view of the river valleys of this region discloses two very distinct topographic features, caused by two equally distinct geologic processes that have dominated the development of the topography during Pleistocene and Recent time. These features are very forcibly impressed on anyone who may have occasion to visit the region. The first is the present-day aspect of the accumulations of a former period of very rapid deposition, the completion of which was the closing event of the Pleistocene period. In their broad surface characteristics these deposits have changed but little since they were laid down. The second is the recent trenching by streams that is so marked a feature of late drainage activity in many other parts in Alaska also and that is brought particularly to notice where streams have worked upon unconsolidated deposits of Pleistocene age. (See Pl. VII, A.) This trenching began with Recent time and results from conditions that still prevail.

The completed result of Pleistocene deposition is presented to-day in the form of gravel and silt plains that extend over all the lower areas. They floor the large main valleys almost completely and extend up the tributary valleys considerable distances into the mountains. Their surfaces slope gradually in two directions-from the sides of the valleys inward to the lower levels occupied by the draining streams, and from the heads of the valleys toward their outlets. They are characteristic valley plains.

The combined ice and water drainage of Pleistocene time, that brought down such vast quantities of rock material from the surrounding mountain ranges, filling the valleys and spreading it out in the form of the gravel plain, has had its gradients and its relation to sea level changed by a widespread elevation which was differential rather than harmonious. The present rivers, in working down to the new grades thus imposed, have cut deeply into the Pleistocene plains (Pl. VII, $A$ ), so that to-day all the streams occupy trenches in the filled valley floor. Thus the valleys are incised from 50 to 600 feet into the unconsolidated Pleistocene deposits, and in many places through them.

Pre-Pleistocene land surface.-To understand more fully the distribution and thickness of the unconsolidated Pleistocene deposits it may be well to indicate briefly what the appearance of this region must have been just before the deposition of the Pleistocene began. This appearance may be imagined from an understanding of the present surface. To-day the country is especially characterized by rugged mountains, most of them showing well up on their sides the effects of vigorous glacial erosion. The sides are steep and in many places descend abruptly to the valley bottoms where the bed-rock slopes disappear beneath the comparatively flat Pleistocene deposits.

The bed-rock contour of the larger tributary valleys of the Chitina to-day present wide U-shaped cross sections typical of strongly 


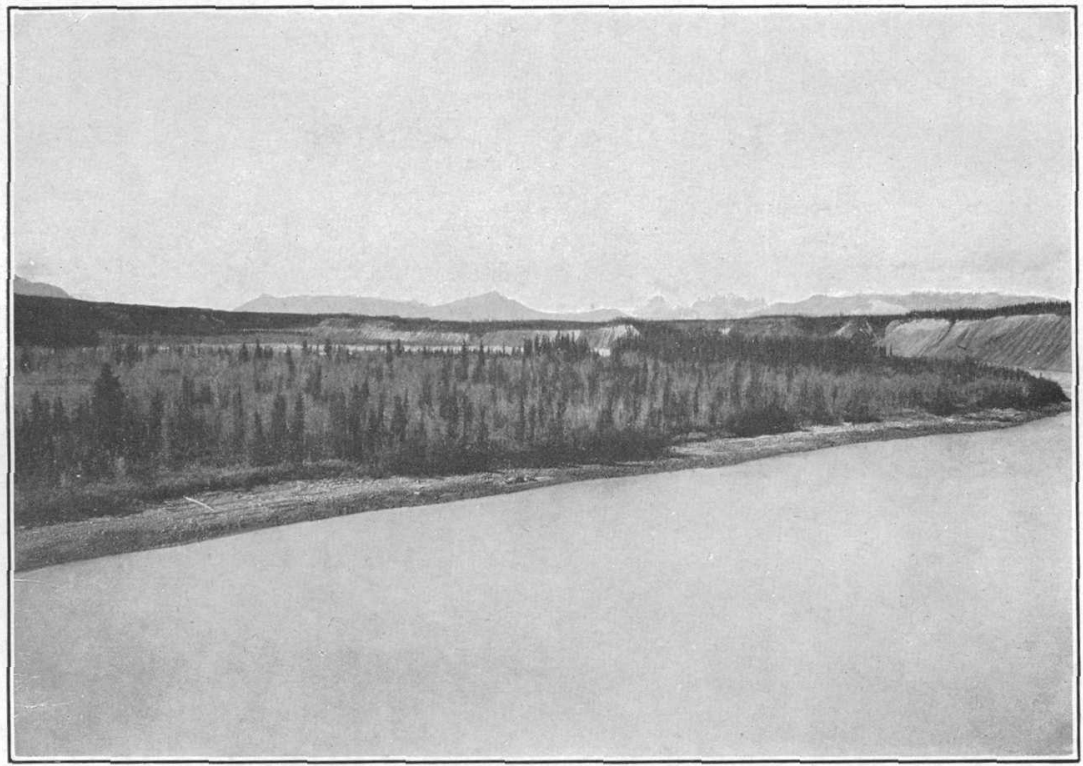

A. PLEISTOCENE GRAVEL BLUfFS.

North bank of Chitina River, above mouth of Nizina River, looking northwest.

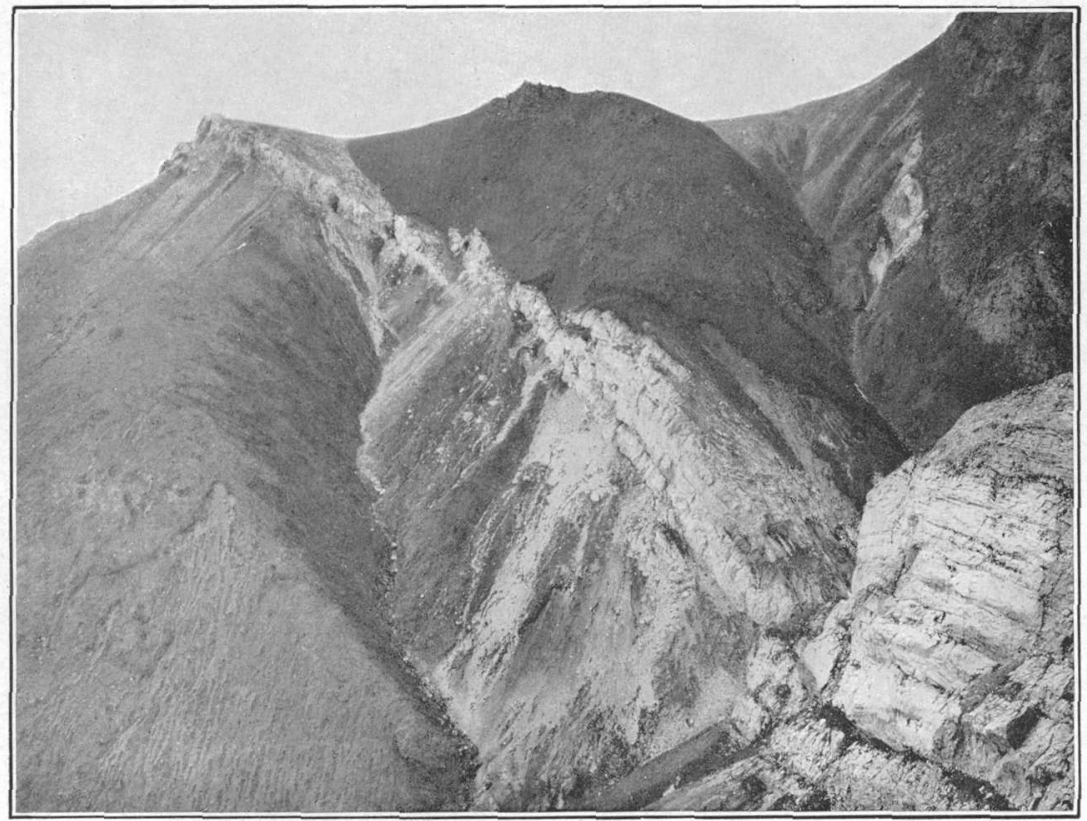

B. CHITISTONE LIMESTONE, NORTH SIDE OF ELLIOTT CREEK NEAR DECEPTION CREEK. Nikolai greenstone below; Kennicott limestone above. 
glaciated valleys, though the bottoms are now hidden in many places to a depth of at least 500 or 600 feet by Pleistocene deposits. Before the glaciers occupied them the broad valleys were no doubt essentially of the uniform deeply eroded rock-floored type, presenting rolling surfaces with here and there considerable hills rising from them, and encircled by high rugged mountains. At that time the mountains had not been glaciated and were not so steep sided, and the valleys were cut deeply only by stream erosion. Even in the main valleys of the Chitina, of the Copper just north of Taral, and of the lower half of the Kotsina, the rock floors were not flat, but presented rolling surfaces, for to-day there are considerable hills of hard bed rock standing above the more level unconsolidated Pleistocene deposits that surround them, like islands in a body of water. The general attitude of these bed-rock islands indicates that the prePleistocene grade of the Chitina Valley was not as steep from the head to its mouth as it is to-day, for the areas of the older bed-rock surface exposed above the unconsolidated deposits are of considerable extent near the mouth of the Chitina, and are less exposed up its valley, where they are more deeply buried by the gravel and are only shown where the main stream and its larger tributaries have cut through the unconsolidated sediments.

The work of Pleistocene time was the filling of these valleys by vast quantities of poorly sorted material eroded by ice and water from the mountains that surround them. The old drainage of the valleys was overwhelmed by an invasion of glacial ice, and erosion and deposition by this ice and its attendant streams left the surface almost as we see it to-day. These unconsolidated deposits are the evidence that tell of Pleistocene time and its activities.

Erosion and deposition during Pleistocene and Recent time.-The Pleistocene and Recent geology of this region is probably brought most conspicuously to our notice by its unconsolidated deposits, but the erosional effects are also marked. The character and extent of the deposits are a direct result of the character and extent of the drainage of that time, and these were dependent on the character of the precipitation. It is not necessary to suppose a larger supply of moisture or a greatly different climate from that of to-day, but the form of precipitation must have been such as to give a great increase in the development of the snow fields that fed the glaciers and their streams. A great change in the character of the drainage appears to have come over the region at the beginning of Pleistocene time. 'This change involved a marked development of glaciers and their attendant streams, together with the greater rapidity of erosion and more active transportation of rock material that accompanies such phenomena. The growth of this kind of drainage seems to have 
been rapid, until it finally dominated the whole area of the CopperChitina region. It apparently had various stages of advance to its maximum extent and then stages of decrease to its present condition. The present character and extent of glaciation is well shown on the map. The detailed stages of its advance have been largely obliterated by its retreat, but the evidences of its greatest development are still distinct, and a detailed study no doubt would bring out much of the history of that period.

Chitina Valley appears to have been occupied by a great valley glacier, and its tributaries, especially the Nizina, Kennicott, Lakina, and Kuskulana valleys-the principal feeders of the master ice stream on the north-were also filled by ice streams that united in the great Chitina Glacier. In addition there were smaller glaciers flowing into the Chitina from the south. The glaciers from the head of Kotsina Valley, together with the Kluvesna and Long glaciers from Mount Wrangell, united with each other and their combined ice stream extended at least to the point where the valley opens out into Copper River basin. Thus it will be seen that this region at some time during the Pleistocene was practically hidden under snow and glacial ice. Only the higher mountain ridges protruded above it, yet even these were the gathering places for snow that fed the glaciers below. As the ice streams moved slowly, but powerfully, down their confining valleys, they were loaded with vast quantities of rock material which they carried with them to the lower level. How long the maximum extent of the ice invasion was maintained is not known, but when the glaciers had reached their greatest development and their increase was stopped by the lack of sufficient snow at their sources to balance the waste by melting at their lower levels, their retreat began. As the melting proceeded and the lower limits of the glaciers withdrew up the valleys, a great quantity of morainal - material was dumped on the valley floors, and the water from melting ice spread this heterogeneous assortment of rock material over the valley flood plains, left bare by the receding glaciers, thus forming the valley-plain deposits almost as they are seen to-day. Melting of the ice did not proceed at a uniform rate, nor was it a continuous course of recession. There were intervals when melting was not so rapid, and then terminal moraines were laid down which the streams issuing from the ice front were unable to spread out in a uniform manner. There were times also when the ice readvanced over areas it had formerly occupied and laid down till sheets of greater or less extent on the unconsolidated partly sorted sediments. Terminal moraine heaps to-day occupy considerable areas in the valley plains and mark positions of halting in the recession of the glaciers to their present positions. Till deposits also occur on top of sediments that were laid down in bodies of quiet water after the first retreat of the 
ice, in order to occupy their present positions in relation to the sediments they overlie, they must have been formed by a readvancement of the ice.

Character of the valley-plain deposits.-The unconsolidated deposits laid down during. the recession of the ice are of various kinds. With few exceptions, they are all sediments of pronounced glacial character and present all the great variety of phases of such deposition, from the unsorted morainal dumps of bowlders, with many angular blocks, to partially sorted cobble beds, regularly arranged gravels, and coarse cross-bedded sands, and in many places considerable areas of typical lacustrine sediments consisting of fine sands and silts. Mendenhall ${ }^{a}$ has described the character of these deposits in the Copper River Valley, and his description applies also to their continuation in the Chitina River valley:

Such deposits' are genérally separated into (1) stratitied or assorted drift, and (2) unstratified or unassorted drift, the first having been laid down under the influence of water, and hence showing a more or less stratified condition, while the second, deposited directly from the ice, consists of heterogeneous aggregates of coarse and fine materials without evident marks of stratification. The two forms are not always readily separable, nor are their relative positions always the same, either: one occurring uppermost, and not rarely they alternate with each other several times between the surface and the bottom of the drift.

The greater part of the deposits that fill the valleys do not show the characteristics of gravel and sand laid down in standing water. Their deposition was governed by more or less local conditions of glacial and stream. transportation and deposition, and these conditions each had its particular features in different localities that changed rapidly from time to time. On the whole, the peculiarities of deposition were a rapid dumping of material, much of which was coarse, into the ample valley basins, and a vigorous fluviatile grading of these materials in the lower areas of the valleys. Each tributary valley furnished an amount of material commensurate with its size and the ability of its stream to transport material out into the larger valleys, where the combined drainage net spread out and graded it all into more even surfaces but was inadequate to do the work of distributing it in uniform stratified deposits of any considerable extent, as might have been done if the deposition had been dominated by a large body of water, such as a lake.

There are, nevertheless, lacustrine deposits consisting of fine stratified sediments occupying more or less restricted areas throughout the valley drift deposits, which show that local lakes of greater or less extent existed in the main valleys, while the streams of tributary valleys were contributing their deposits of heterogeneous material.

a Mendenhall, W. C., Gcology of the central Copper' River region, Alaska : Prof. Paper U. S. Geol. Survey Nio. 41,1905 , pp. 64-74. 
The outflow of andesitic lava indicated southwest of Mount Wrangell on the geologic map (Pl. II). occurred after a large part of the Pleistocene deposits. had been laid down, as is shown by the fact that it overlies a considerable thickness of these sediments. This relation has been examined by Schrader and Spencer ${ }^{a}$ along Chetaslina River. They also noted a deposit of fragmental volcanic material in the sediments directly-underneath the lava, which they associate with this outburist of volcanic activity. This fragmental material shows every appearance of having been ejected from craters in the form of bombs only a short time before the outflow of lava began. Fragmental volcanic material of this nature was observed by the present writers in the benches of Pleistocene sediments of the Kotsina Valley opposite the mouth of Roaring Creek. At this locality there is no lava overlying the material, but the bomb-like fragments have a rough stratiform arrangement under about 30 feet of gravels and silts. The bombs at this locality have a porous friable texture, and occur as roughly spherical masses from a few inches to a foot or more in diameter.

After the outflow of lava had taken place the area was again overridden by the glacier, as is shown by the fact that the surface of the lava has been smoothed by moving ice, and deposits of glacial débris lie upon it.

\section{ECONOMIC GEOLOGY.}

\section{GENERAL STATEMENT.}

The mineral resources of the Chitina and the Kotsina River valleys that are of present commercial interest are gold, copper, and possibly coal.

Gold has been mined from the Nizina placers since 1902. As in many other placer regions, however, no records of the early production are available, and no attempt is here made to give even approximate figures for the yield of gold in these six years. Gold placer mining is now on a more firmly established basis than in the past, and doubtless an increase in the yield of gold will be seen in the next few years. Possibly this yield may be increased further by an extension of the producing area as the conditions for economical mining grow more favorable.

Copper, because of the high price of that metal from 1905 to 1907, has received much attention from prospectors and others interested in copper production, but this region has not yet produced a pound of copper in a commercial way.

The coal deposits of Chitina Valley are probably of only local interest. No coal comparable in quality with the coal of Controller

a Schrader, F. C., and Spencer, A. C., op. cit., p. 59. 
Bay or Matanuska River has been found, yet, if obtainable in proper quantity, the Chitistone River coal may have a small local demand.

At present, then, the Kotsina-Chitina area has an actual production of gold and a prospective production of copper, but, without detracting in any way from the importance of its gold placers, it may be said that the future position of the region as a producer of mineral wealth may be determined in large part by the importance which its copper deposits assume on development.

In this paper greater attention is given to the copper deposits. It is hoped that the facts observed are presented impartially and in such a way as to give a proper idea of the type of ores occurring here and of the progress.in developing them since they were last visited by members of the Survey. Those seeking information in regard to the commercial value of the deposits described may be disappointed in finding no definite statement in regard to values. It has become the established practice in the Alaskan investigations of the Geological Survey not to treat this subject, for it evidently falls within the province of the mining engineer who investigates a particular property. In the short time available for their study it would obviously be impossible for the Survey geologists to sample the deposits visited, and it also appears unwise to publish the results of assays furnished by property owners, because it is not always possible to learn how a given sample was taken. It is admitted that the descriptions are in no way exhaustive. This is necessarily so from the conditions under which the work was done. In the first place the copper properties are all prospects and not developed mines. The ores examined are near the surface and are exposed in shallow open cuts or in short tunnels, so that there is little data at hand for determining the character of the ore in depth or for obtaining an accurate idea of the form of the ore bodies. In the second place time was too short to make a thorough examination of all the properties in the region. A few prospects were not visited because their locations were not definitely known, and in the absence of the owners either they were not found when searched for or it did not appear to be in accord with the best interests of the work to spend time in looking for them.

The omission of the name of a claim in the descriptions to follow, therefore, reflects in no way on the value of that claim. On the other hand, in a few instances where there was more than the usual opportunity for studying the ores it is possible that the more nearly complete descriptions of them. will make it appear that they were considered to be of unusual promise or value. These more detailed descriptions, however, are given in the hope that they may lead to a better understanding of the copper deposits by the reader and enable him to draw his own conclusions respecting the character of the ores. Knowing 
the harm that sometimes is caused by premature or hasty conclusions the writers have endeavored to state facts rather than inferences in the hope that more detailed and thorough studies may be made in the future.

\section{COPPER.}

THE COPPER MINERALS.

Preliminary statement.-The copper minerals most common in this region are not many. Those associated with the copper are even fewer. The copper deposits, therefore, so far as their mineralogy is concerned, are not complex, but it is difficult with the data at hand to give an outline of their history that is fully satisfying. Copper was seen in greatest amount as chalcocite, bornite, and chalcopyrite. Nạtive copper should probably be mentioned after these. Malachite is the most noticeable of all the copper minerals. Azurite, cuprite, chalcanthite, and tenorite occur locally. Calcite, quartz, and epidote are associates of the copper minerals in some places.

Descriptions of all the minerals named are to be found in any book on mineralogy, but for the convenience of those who may not have such books at hand their chemical composition and percentage of copper will be given in describing the copper minerals as they occur in this region.

Native copper.-Native copper is found in the Nikolai greenstone in many places. It is believed to be entirely of secondary origin, and occurs most commonly either without quartz in the amygdaloidal lava flows or accompanied by quartz, or quartz and epidote, in small veins or shattered portions of the lava flows. It appears to prefer the amygdaloidal phases of the greenstone rather than the more compact beds such as the coarser grained diabase lying immediately below the Chitistone limestone, yet native copper is found there also. It takes the form (1). of small grains and slugs formed by alteration or replacement, or deposited in cavities which were either produced when the lavas solidified, or else resulted later from soblution, and (2). of thin crumpled leaves or films deposited along fractures resulting from strains and movements in the rock. In places the copper forms small lenticular veinlike masses, or it occurs as a network of intersecting seams almost like the complex of quartz veins sometimes seen in a rock that has been brecciated and recemented. This last phase is particularly common where the copper, accompanied by quartz, has filled cavities in the country rock. When such a mixture of quartz and copper is struck with the hammer so as to shatter the more brittle quartz, it leaves a cavernous or spongelike mass of copper. That the copper has in some places filled open cavities seems to be shown by the presence of perfectly formed quartz crystals in it. In at least one place native copper is restricted to a particular lava flow and is not seen in the flows lying immediately 
above and below. At this locality it is associated with a black glassy amygdaloidal filling consisting of a mixture of copper oxide and carbonaceous matter. The copper is present as grains and films in the amygdules and also in the greenstone. No quartz was seen here, but it was reported that a mass of copper and quartz weighing 60 pounds was taken from an outcrop only 400 or 500 feet distant. This is the largest piece of native copper found in place reported to the writer.

Native copper is found in the gravels of several streams, such as Nugget, Dan, and Chititu creeks. The largest piece yet discovered is on Nugget Creek. It is estimated to weigh between 2 and 3 tons. Native copper is common in the gravels of Dan and Chititu creeks, the pieces ranging in size from small grains to masses of 300 pounds weight. The copper is all more or less rounded and some of the pieces assume most fantastic shapes. Native copper and native silver crystallized together in the same nugget are not uncommon. As a rule the placer copper is nearly free from quartz, but is considerably oxidized, and some pieces when broken are found to be spongy or cavernous. Native copper was not seen in the Chitistone limestone.

Cuprite.-The dark-red oxide of copper, cuprite $\left(\mathrm{Cu}_{2} \mathrm{O}, 88.8\right.$ per cent copper), is found in the Chitina region, where native copper is found, and usually does not occur without it. It is difficult or perhaps impossible to determine, whether the native copper results from the reduction of the cuprite or the cuprite from the oxidation of the copper. Probably both changes take place. Cuprite is not known in the Kotsina-Chitina country in quantities sufficient to make it of value as an ore. Many of the placer copper nuggets show little crystals of cuprite when the oxidized scale is broken from the surface. Cuprite is also seen as little red specks in copper-bearing greenstone or on the native copper in the greenstone.

Tenorite.-The black oxide of copper ( $\mathrm{CuO}, 79.8$ per cent copper), tenorite or melaconite, is of rare occurrence in this region. Together with a certain amount of carbonaceous material it forms a black, glassy or resinous filling of cavities in some of the amygdaloidal lava flows. It also was found in one place in association with the quartz of a small vein filling.

Chalcocite--The cuprous sulphide, chalcocite, frequently called copper glance $\left(\mathrm{Cu}_{2} \mathrm{~S}, 79.9\right.$ per cent copper $)$, forms the most valuable of the known copper deposits of Chitina Valley. It is found in the Nikolai greenstone at many places from Kotsina River to the Chitistone, but its greatest deposits are in the Chitistone limestone. It is more abundant in the eastern part of the field than the western. In the greenstone it forms irregular lenticular and veinlike bodies, replacing the rock, or is disseminated through it in small particles. In places it is associated with epidote. Large masses of practically pure 
chalcocite were formed in the Chitistone limestone by replacement of the original rock. It is unoxidized save for a thin film on the surface, and breaks with a smooth, shining fracture, like stove polish. Both here and in the greenstone it may more probably be of secondary origin, but from what original mireral it is derived is not known.

Bornite.-On. the whole, bornite $\left(\mathrm{Cu}_{5} \mathrm{FeS}_{4}, 63.3\right.$ per cent copper $)$ is perhaps the most widespread copper mineral of the region. It is found in the greenstone and in the limestone near the limestone-greenstone contact, but it is much more common in the greenstone. The bornite usually occurs without accompanying minerals other than those of the altered greenstone. It is also seen, however, accompanied by calcite and a minor amount of quartz in veins. In the greenstone it assumes practically the same form as does chalcocite, that is, it is disseminated in grains through the rock or occurs in it in irregular veins or lenses. Sheared portions of the greenstone in places show a mixture of more or less replaced country rock and nearly pure bornite. Thin sections of the ore show that the greenstone, while it appears in the hand specimen to be quite fresh, is nevertheless highly altered and contains much secondary calcite. In some thin sections the ferromagnesian minerals are practically lacking. The bornite is scattered through the rock in small grains that are in places intergrown with chalcopyrite. This intergrowth of bornite and chalcopyrite on a much larger scale is usual in the vein deposits accompanied by a calcite gangue.

Chalcopyrite.-So far as prospecting has shown, chalcopyrite ( $\mathrm{CuFeS}_{4}, 34.6$ per cent copper), is not an abundant copper mineral in the region under discussion, but it accompanies bornite in a great many places, forming an intimate intergrowth with it. It may not be distinguishable in a hand specimen, but many of the thin sections examined under the microscope show it to be present. Where chalcopyrite and bornite are accompanied by calcite in vein deposits the two minerals crystallize in larger masses than in the greenstone, and with the white calcite background they form a handsome ore. It is natural to expect that the rich sulphide deposits may have been derived from poorer pyritic ores, and proof of this was sought, but no conclusive evidence on this point was discovered.

Malachite.-The green copper carbonate, malachite $\left(\mathrm{Cu}_{2}(\mathrm{OH})_{2}\right.$ $\mathrm{CO}_{3}, 57.5$ per cent copper), forms a stain on the copper minerals and on the inclosing country rock wherever copper is found. In most places it is conspicuous in a degree entirely out of proportion to the quantity of copper present and is apt to give one a greatly exaggerated idea of the deposit it marks. Malachite forms a green film that covers exposed surfaces of ore and rock and penetrates along joint planes and fractures wherever the copper-bearing waters find an entrance. Though it is the most widespread and noticeable. of 
all the copper minerals, it is not known to be present anywhere in the region in sufficient amount to make it of importance as an ore. In a few places it forms small deposits in broken limestone. Weed ${ }^{a}$ in describing this mineral says: "Owing to its brilliant green color a very small amount will stain a very large amount of rock or vein matter, or color thin and worthless incrustations or nodules of valueless material, so that it is difficult and, in fact, often impossible to form any accurate opinion of the ore from its external appearance."

Azurite.-The blue carbonate of copper, azurite $\left(\mathrm{Cu}_{3}(\mathrm{OH})_{2}\right.$ $\left(\mathrm{CO}_{3}\right)_{2}, 55.3$ per cent copper), is much less common in this part of the Copper River region than malachite. It is found chiefly in connection with deposits of chalcocite in limestone, and in places is clearly an alteration product of the chalcocite. At the Bonanza mine azurite forms small veins or veinlets in joints or fractures of the limestone around the boundaries of the main ore body. Some of the veins when broken show a core of chalcocite. Azurite also forms beautiful deep-blue crystals on the chalcocite. On the whole, it may be said to be an uncommon mineral in this region and.is rarely seen as an alteration product of the ores in greenstone except where they are accompanied by calcite.

Chalcanthite.-The blue copper sulphate, chalcanthite $\left(\mathrm{CuSO}_{4}\right.$ $5 \mathrm{H}_{2} \mathrm{O}, 25.5$ per cent copper), was observed in a few places where water seeping from the copper-bearing greenstone had evaporated, leaving small crystals of the sulphate on the rock surface. It is easily recognized by its appearance and acid taste. It is of no importance as a copper ore in this region.

\section{OCCURRENCE OF THE ORES.}

General statement.-The copper ores of the region are associated with the Nikolai greenstone and the Chitistone limestone. Copper is widely distributed through the greenstone, but the largest and most valuable of the known deposits are in the limestone very close to the limestone-greenstone contact. Copper, however, was not seen in the Chitistone limestone at any considerable distance above the green-. stone; that is, the copper minerals found in the limestone can be shown in almost every instance to be near the base of the formation and consequently near the greenstone. All of the important known deposits in limestone are in the eastern part of the district. The deposits in greenstone, on the other hand, do not appear to be more developed in one locality than in another.

The copper ores may be referred to one of the three following classes: (1) Copper and copper-iron sulphides associated (a) with 
greenstone and $(b)$ with limestone; $(2)$ native copper associated with greenstone; (3) placer copper.

On the basis of form the first class, and to a certain extent the second also, may be divided into (1) vein deposits and (2) deposits of irregular shape to which the name "bunch deposits" has been applied. Under veins are included the deposits of tabular form. In nearly all places obseirved they are clearly associated with fault planes or shear zones, and are accompanied by the vein minerals calcite and quartz, with epidote also present in some places. Ore bodies of this nature approach more nearly to the geometric form commonly ascribed to "fissure veins."

Regularity and definiteness of outline, however, are not characteristic of the Kotsina-Chitina ore bodies. In by far the greater number of places they have an irregular form that Mendenhall has described under the term "bunch deposits." a This term is not entirely satisfactory, but it probably describes as closely as any one word the form of ore body most common in the Kotsina-Chitina region. It does not necessarily imply a mass of ore composed of copper minerals alone, since most of the ore bodies to which the term might be applied are not such masses, but it does suggest an approach to something like equality in the dimensions of the ore-bearing rock mass, and especially it conveys an idea of separation of one body from other bodies.

It has already been pointed out that faulting is common in the rocks of the Wrangell Mountains. Some of the faults are of great displacement, but most of them are small.; Crushing and shearing are slightly different expressions of the same disturbances that produce the faulting. Openings produced in this way have given opportunity for extensive circulation of waters that carried and deposited copper minerals. Most of the channels must have been exceedingly variable in form and direction, because regularly formed and clear-cut veins are so rare in the region. This is particularly true of ore bodies in the greenstone.

Copper sulphide deposits in greenstone and limestone.-The copper ores in greenstone are prevailingly bornite with smaller amounts of chalcopyrite, chalcocite, and native copper in approximately the order given. In limestone the ores are chalcocite, bornite, and chalcopyrite. The surface oxidation product in greenstone areas is malachite. In limestone azurite is common as an oxidation product, but perhaps no more abundant than malachite.

Copper ores in the greenstone are composed in many places of country rocks and copper minerals without accompanying vein minerals. The copper sulphides occur in shear zones or in jointed and

a Mendenhall, W. C., Geology of the central Copper region, Alaska : Prof. Paper U. S. Geol. Survey No, 41,1905, p. 42 . 
shattered portions of the rock; they fill fractures in the rock and also occur as a replacement of it. As has been stated, bornite is the most common copper mineral in the greenstone, but chalcopyrite is probably always present with it. All the thin sections of bornite ore examined showed chalcopyrite in small amount. In some of the calcite vein deposits chalcopyrite is nearly, if not quite, as abundant as bornite. Chalcocite is seen in the greenstone in some places accompanying or accompanied by bornite, or by bornite and chalcopyrite, a relation suggesting the derivation of the chalcocite from the poorer sulphides. A careful examination of the ores in greenstone is usually necessary to determine the limit of impregnation, which is not marked by any definite boundary, the replacement becoming gradually less with increasing distance from the center of impregnation. In limestone areas, on the other hand, the transition from ore minerals to country rock is more abrupt and the boundary surface is more easily determined. Unfortunately deposits in limestone appear to be less numerous than those in greenstone. The large size of the chalcocite bodies in limestone and their comparative freedom from included fragments of the country rock, such as are always present in the greenstone ores, is probably due to the grater solubility of the limestone. There is a possibility also that some chemical quality of the limestone gave it greater precipitating power than was possessed by the greenstone and made it a more favorable place for deposition of copper minerals from solution. This, however, is offered merely as a suggestion, for it can not be proved with our present knowledge of the conditions during ore deposition.

Where copper minerals are associated with gangue minerals in veins the gangue is chiefly calcite, but is usually accompanied by a small amount of quartz. One of the striking features of the copper: deposits throughout the region is the scarcity of quartz accompanying them. Veins of quartz and epidote are of local importance, but on the whole calcite is the prevailing vein mineral. Veins and stringers of calcite, as well as small grains of that mineral, are found throughoui the greenstone, but are more abundant near the top. 'Part of the calcite may have been derived from the overlying limestone, but a second scurce of calcite is the basic feldspar in the greenstone. All the thin sections of ore in greenstone show a rock more or less decomposed in which secondary calcite is common. Although it would be difficult or impossible to prove that the calcite in a particular case was not introduced from other sources than the greenstone, the possibility that some of it has that origin is to be considered. So far as could be determined at the exposures, the veins of this kind that were examined are subject to rapid changes in thickness from place to place. Few of them were traced for any considerable distance. 
This statement, however, is not to be interpreted as implying that they do not so continue. At several localities variation in the thickness of the veins is plainly due to faulting later than the ore deposition and oblique to the veins. Slight movements along such faults may either increase the thickness of the vein or diminish it according to the direction of the movement. It is perhaps safe to say that the effects of faulting will be one of the difficulties encountered in mining in this region.

Native copper associated with the greenstone.-Native copper is associated with amygdaloidal phases of the Nikolai greenstone and is also found accompanied by quartz or by quartz and epidote in veins cutting the greenstone. Most commonly it occurs as grains and small slugs in the amygdules and disseminated through the greenstone and as films or leaves and small veinlets cutting the greenstone. Tabular masses deposited in joint planes also occur and without much doubt indicate the way in which the large mass of native copper on Nugget Creek was formed. Such masses. were not seen in place in Chitina Valley, but they have been found east of Skolai Pass near the head of White River. In a few places native copper occurs in amygdaloidal greenstone in association with a mixture of copper oxide and carbonaceous matter filling the cavities of the lava. Much of the native copper is probably secondary and is thought to have resulted from the reduction of previously deposited sulphides or oxides. What part, if any, is primary is a question which it is difficult to answer.

Placer copper.-Copper is present in stream and bench gravels in a number of localities, particularly on Chititu, Dan, and Nugget creeks. It is found in pieces ranging from the size of shot to masses weighing hundreds of pounds or even several tons. Native silver accompanies the copper, either in nuggets of silver only or united with the copper in the same nugget, showing that the solutions depositing the copper carried silver as well. The source of the two metals is not definitely known, but the native copper deposits in the greenstone are naturally suggested as a place from which they are most probably derived.

\section{SOURCE AND CHARACTER OF THE COPPER DEPOSITS.}

The wide distribution of copper minerals throughout the Nikolai greenstone leads to the belief that the copper has been derived from the greenstone and owes its present concentration to the action of circulating waters. No evidence at hand warrants either affirming or denying a more deep-seated source for some of the copper-bearing solutions, but the weight of evidence is in favor of a local source for the copper. 
The occurrence appears similar in this respect to that of the Lake Superior copper deposits, in accounting for which Van Hise says: ${ }^{a}$

In this region the only locality at which the ore has been found in paying quantities is at Keweenaw Point, and the productive district is at present confined to a very small area about Calumet and Houghton. Notwithstanding this fact, there is scarcely a locality in the Lake Superior region where the Keweenawan basic lavas occur in which small amounts of copper are not found. Almost every porous amygdaloid shows flakes of it. In many localities it is so abundant that extensive exploration has been undertaken with the hope of finding ore bodies, as, for instance, in Douglas.County, Wis., Isle Royal, and Mamainse. But all these explorations have resulted in failure. To me the almost universal association of small quantities of copper with the Keweenawan lavas is the most conclusive evidence that these lavas are the source of the metal.

It is a noteworthy fact that the Kotsina-Chitina region has been one of considerable volcanic activity since the time when the Nikolai greenstone was poured out, as is shown by the large amount of igneous rocks present-porphyritic intrusives, Tertiary volcanics, and Recent andesite flows. Steam issues from Mount Wrangell at the present time. It seems that the presence of such heated rock masses must have greatly promoted the circulation and solvent power of water in the rocks, whatever the source of that water may have been. The formation of ore bodies would appear to be due to the migration of copper minerals taken into solution and redeposited in more concentrated form in favorable locations by water circulating through the greenstone.

The study of ore deposits in many other places has shown that in typical examples the character of the ore is not uniform from the surface to the lowest parts of the deposit, but that ore bodies may be divided into three zones, each of which has its own characteristics but is not sharply separated from the one immediately above or below it. These three zones are the upper zone of oxidized ore, the zone of enriched sulphides, and the lower zone of unaltered sulphides. In attempting to divide the copper deposits of the Kotsina-Chitina region, according to this arrangement, it is immediately seen that they do not fully correspond with the ideal case. There is no zone of oxidized ore in the deposits of this region, such as is commonly seen in many other districts. Oxidation products in nearly every instance are confined to a thin film on exposed ore surfaces or along fracture planes in ore that has not been exposed directly to weathering or in fractures in country rock adjacent to ore.' This absence of an oxidized zone is general throughout most of Alaska, and is due to climatic conditions. Many of the large masses of copper minerals have been exposed directly to the weather for a long period of years, but the mechanical breaking down of the ore body and inclosing rock has kept pace with

\footnotetext{
${ }^{a}$ Van Hise, C. R., A treatise on metamorphism : Mon. U. S. Geol. Survey, vol. 47, 1904, p. 1103 .
} 
or has exceeded the rate of chemical alteration. The talus slopes on both sides of the ridge at the Bonanza mine contain a large amount of unaltered chalcocite fragments derived from the outcrops of the ore body above. Float ore is present in streams, and either shows nothing but a thin surface alteration or is practically fresh.

It is desirable to determine, if possible, to which of the two lower zones the present ore bodies belong, whether they were deposited in their present form, and are therefore primary ore bodies, or whether they have resulted from alteration and enrichment of previously existing ore bodies, and are therefore secondary. This question is of importance because it will help in forming an opinion of the character of the ore bodies that may be found at depth. If those now exposed are shown to be secondary enriched ores, then it may be expected that the deeper ores will be leaner. If on the other hand they are primary, there is no reason to suppose that the deeper ores may not be as rich as those at the surface. To answer this question with confidence would require more time and closer study than it was possible to give. No deep workings have been made, and there is no evidence from that source concerning the probable character of the ore at depth.

It is nevertheless desirable to state such facts as throw any light on the problem. From studies of many ore deposits it is known that the ground-water level is an important factor in the consideration of veins whose original material has been modified by the action of surface water. Above the water table the vein, as well as the country rocks, are most rapidly affected by the ordinary processes of decay, and material is taken into solution by circulating water to be brought to the surface or to be carried downward and redeposited. By such solution and redeposition an enrichment of the lower part of a vein may take place. Such enrichment has been found to be more or less closely connected with the ground-water level and to a certain extent gives ground for the belief generally held that the richness of ore deposits increases with depth. The depth at which ground water is encountered varies in different districts and localities. In some regions it is found near the surface; in others it is not encountered until a great depth has been reached. From the evidence at hand it appears that the ground-water level in the region under discussion is near the surface in most places and in many places reaches it. Furthermore, mechanical breaking down of the ores and country rock is so rapid at present as to prevent the formation of an oxidized zone, and consequently of an enriched zone. It therefore seems improbable that secondary ores are forming or have formed under present conditions, but it is still possible that the ores may be secondary ores formed in a previous cycle when conditions were different from what they are now. 
There are a number of facts that may be stated as having some bearing on the primary or secondary character of the ores. The evidence, however, is for the most part of a negative rather than a positive character and is consequently more or less unsatisfactory. All of the ores under discussion that are of possible economic value are secondary in the sense that they are concentrations from copper disseminated through the greenstone, possibly in the form of one of the two sulphides just mentioned or contained in some of the constituent minerals resulting on consolidation of the magma. Clarke ${ }^{a}$ in discussing the relations of the several sulphide minerals of copper has stated that " chalcopyrite and bornite are probably the primary compounds from which the others in most cases are derived, and they have been repeatedly identified as of magmatic origin." It is, however, the primary or secondary character of the ore bodies themselves, irrespective of their original source, that is under discussion, and the following statements have reference to this question:

(1) All the copper sulphides that have been described are known to occur as primary minerals in ores, and the fact that a given ore is composed of bornite or chalcocite is not necessarily evidence of its secondary character.

(2) The absence of the leaner sulphides-chalcopyrite and bornite-in such chalcocite deposits as that of the Bonanza mine might be considered as presumptive evidence that the chalcocite was deposited primarily as such and not secondarily by the alteration and enrichment of an earlier ore body.

(3) In considering the ores in greenstone it should be stated that, while bornite is the prevailing copper mineral and in many places chalcopyrite may not be distinguished by the eye alone, yet nearly all of the thin sections examined under the microscope show it to be present either intergrown with bornite or surrounded by it. This is true of both vein and "bunch deposits" and suggests an alteration of primary chalcopyrite to bornite as being more probable than a simultaneous deposition of the two minerals.

(4) Chalcocite, although it is held to be primary in some localities, is usually considered a secondary mineral. In the Bonanza ore body chalcocite is practically the only mineral in the limestone. Neither chalcopyrite nor bornite was found in the ore. Yet immediately below the contact in the same shear zone bornite, chalcocite, and native copper are present in small amounts. If the sulphides in the greenstone are secondary, it appears more probable that the ore in limestone is secondary also.

(5) "Native copper is commonly, if not always, a secondary mineral, either deposited from solution or formed by the reduction of some solid compounds." $b$

a Clarke, F. W., The data of geochemistry : Bull. U. S. Geol. Survey No. 330, 1908, p. 568.

$\checkmark$ Idem, p. 564. 
If these facts are considered in the light of experience in other regions, they appear to favor a secondary rather than a primary character for the sulphide ores in greenstone, but they leave still greater doubt concerning the chalcocite deposits in limestone. No reason was discovered why any of the ore bodies examined should increase in richness and value with depth through any other cause than by an increase in the size of the ore body. It is believed that the surface indications in most places give a fair idea of the maximum richness of the deposits in so far as that richness depends on the character of the copper minerals resulting either from enrichment or from oxidation and removal in solution of minerals in the upper part of the ore bodies.

\section{DESCRIPTION OF PROPERTIES.}

Copper prospecting in the Chitina region is carried on from a few central localities, of which those receiving most attention are Kotsina River (including Elliott Creek), Kuskulana River, Kennicott River, and Chitistone River. These centers are named from west to east, in the order in which they were visited, and the prospects will be described in the same way.

\section{KOTSINA RIVER BASIN.}

Kotsina River receives a large part of its water from snow fields and glaciers on the southern slopes of Mount Wrangell and joins Copper River 2 miles above the Chitina. Much of the drainage area is occupied by Nikolai greenstone, but the limestone, shales, and conglomerate are all present. Prospecting is most actively carried on in the upper part of the basin and on Elliott Creek. The upper tributaries include Peacock, Surprise, Roaring, Ames, Rock, Kluvesna, and Copper creeks. No work has been done here which can properly be called mine development, as there is no place where sufficient work has been done to demonstrate the presence of a mine.

KOTSINA RIVER.

Practically the only prospecting on the Kotsina itself is that done by the Great Northern Development Company. This company is the largest one carrying on operations on the Kotsina, to which, however, its interests are not confined. The headquarters of this company are on the Kotsina River at the mouth of Roaring Creek, and its equipment includes a sawmill and telephone connection with the government telegraph line at Tonsina. Probably 100 men were employed during the summer. The prospects on the river include five short tunnels, the nearest of which is about one-half mile below the camp. They are within a short distance of one another on the south, 
side of the river and almost on the same level with its broad gravel floor. None of these tunnels had been driven farther than 20 feet in August, 1907. At the first tunnel a porphyritic dike 10 feet thick cuts a fine-grained greenstone. Its course is $\mathrm{N}$. $30^{\circ} \mathrm{W}$. and it is bounded on both sides by fault planes. A little copper-bearing pyrite was deposited along the faults in the fractured rock. At the second tunnel, a few hundred feet to the west, a quart\% vein varying from 4 to 6 inches in thickness contained a little copper pyrite. The vein has a strike $\mathrm{S} .50^{\circ} \mathrm{W}$. and cuts the greenstone in a perpendicular direction. At the other three tunnels a little pyrite is present in the greenstone, and its oxidation gave the brown stain by which the tunnels were located.

AMES CREEK.

Ames Creek is the first stream below Roaring Creek on the south side of Kotsina River. It is a small stream in a hanging valley and like nearly all the tributaries of this river owes the broad round cross section of its valley to the work of glacial ice. The copper prospects include three tunnels, the property of the Great Northern Development Company, known as tunnels 6,7 , and 8 .

Tunnel 6 is on the west side of Ames Creek, 1,400 feet above its mouth. Early in August, 1907, it had been driven 50 feet in a southwesterly direction in frozen slide rock from the hill above. Country rock in place had not been reached. About 100 feet above the tunnel a little pyrite is seen in a dense, hard, faulted greenstone.

On the east side of Ames Creek, 50 feet higher than tunnel 6, is tunnel 7, which runs N. $30^{\circ}$ E. for 70 feet through loose slide rock before reaching the undisturbed greenstone, which here is fine grained and stained with iron from the oxidation of pyrite.

Tunnel 8 is also on the east side of Ames Creek, one-fourth mile south of tunnel 7. It has been driven for 30 feet in amygdaloidal greenstone, but no copper has been found.

ROCKK CREEK.

Rock Creek is one of the largest southern branches of the Kotsina and heads against Strelna and Nugget creeks, tributaries of Kuskulana River. A horse trail crosses the divide from Rock Creek to Strelna Creek and is the shortest route from upper Kotsina River to Chitina Valley. Active prospecting was confined to Lime Creek, a tributary of Rock Creek, which joins it from the east. The Warner prospect, at the mouth of Rock Creek, which was visited and described by Mendenhall in 1902, is now patented and no further work has been done on it. Lime Creek flows near the limestone-greenstone contact, and the copper deposits, although mostly northeast of the creek on the opposite side from the southwestward-dipping limestone, are not far from it. The prospects are near the point where the Rock Creek 
trail crosses Lime Creek. In July, 1907, a tunnel was being driven in the greenstone just below the limestone, only a few feet above the creek, but no ore had been found at that time.

Several hundred feet up the hill to the northeast was a tunnel 20 feet in depth in jointed greenstone. The principal copper mineral. is bornite, which occurs in the greenstone as lenses or irregular lumps that have diameters from one to several inches. These patches, as far as the present surface shows, appear to be unconnected. Bornite also occurs filling fractures in the rock and forming small lenticular veins, but it appears principally in joint planes, on whose surfaces it forms a veneer that in places is an eighth of an inch or more in thickness. There are small veins of calcite and quartz.

About 50 feet farther east is an open cut showing similar rock and ore, although here the ore is in greater amount. The bornite occurs in sheared greenstone, cut by small faults striking N. $35^{\circ} \mathrm{E}$. and dipping $60^{\circ} \mathrm{S}$., and forms a lens-shaped mass 2 feet thick. The greenstone has nearly been replaced by bornite.

At a point 200 feet farther north and 100 feet higher is an open cut in amygdaloidal greenstone. The cavities are now filled with quartz or with a dark mineral, possibly chlorite. Several faults with gouge and zones of crushed rock up to 1 foot in thickness cut the greenstone with a strike of $\mathrm{N} .15^{\circ} \mathrm{E}$. and a dip ranging from $60^{\circ}$ to $70^{\circ} \mathrm{E}$. A little copper stain was seen along the crushed rock, but no other copper minerals are present, although bornite is found in the slide rock near by.

ROARING CREEK.

Roaring Creek is a southern tributary of Kotsina River, which it joins a short distance above the main camp. It heads in a small glacier and flows through an open valley several hundred feet higher than the level of Kotsina River. The country rock, except one small limestone area on top of the ridge between Roaring Creek and Peacock Creek, is greenstone, but the greenstone is not of uniform character, for slaty beds and hard, fine-grained, cherty-looking beds are intermingled with amygdaloidal flows. Most of the prospects are in the upper part of the valley.

The Great Northern Development Company has several prospects on Roaring Creek. One of these is located on the south side of a small gulch west of Roaring Creek near the camp known as camp 3. A tunnel was started in gray and black mottled slates near a fault plane which separates them from a greenstone mass. The strike of the slate cleavage and of the fault plane is the same, No. $20^{\circ} \mathrm{W}$., and the dip is steep. The tunnel is perpendicular to the strike. There is some brown iron stain resulting from pyrite alteration, but no copper ore had been found. 
Another tunnel was being started on the east side of Roaring Creek about half a mile above the tunnel just mentioned, but not enough work had been done to show the presence of ore. A piece of greenstone picked up near this place contained small particles of native copper.

Above camp 3, on the west side of Roaring Creek, a tunnel 50 feet long had been driven by the California-Alaska Mining and Development Company. This tunnel is 2,600 feet above the mouth of Roaring Creek and at least 1,500 feet above camp 3. The country rock is greenstone, and the ore consists of small calcite-quartz veins containing native copper and azurite. In the slide rock in a little gulch a few feet north of this tunnel, but some distance below it, a nugget of native copper was found, which was taken to Valdez and is reported to weigh about 800 pounds.

The Kotsina Mining Company ${ }^{a}$ holds several claims on Roaring Creek. Among them are the Skyscraper and associated claims, located near the small limestone area previously mentioned. Several open cuts and short tunnels have been made, and in July, 1907, the company was starting a tunnel on an exposure of copper minerals 350 feet below the base of the limestone at the northern end of the area. This cut exposed a lenticular mass of chalcocite 6 inches thick and 3 feet long, as seen on the face, lying horizontally in the rough, coarse-grained greenstone that occurs immediately below the Chitistone limestone. In the vicinity are several greenstone exposures in which chalcocite forms small patches or lenses. They are seemingly in no way related to one another.

PEACOCK CREEK.

Peacock Creek joins Kotsina River about 2 miles below the more southerly of the several large glaciers from which the river receives its water supply. There are two branches of the stream, one extending toward the east and the other toward the southeast. The eastern branch originates in a small glacier, and the valleys of both branches were formerly occupied by glaciers. Greenstone is the country rock except for the limestone mass on the ridge between Roaring Creek and the more southerly branch of Peacock Creek. Dikes of diorite cut the greenstone, probably apophyses of the diorite mass on the north side of Kotsina River. The copper prospects of Peacock Creek are owned by the Alaska Kotsina Copper Company.

Rose claim.-The Rose claim of the Alaska Kotsina Copper Company is located on the point of the ridge between the two branches of Peacock Creek. It is a little more than 2,000 feet above the valley

a The use of the name Kotsina, Mining Company has been abandoned by the owner of this property since this paper was written, but the name used in its place has not been learned. 
of Kotsina River. The greenstone is cut by a perpendicular fault striking $\mathrm{N} .25^{\circ} \mathrm{E}$. This fault is easily traced for a distance of nearly 400 feet and is indicated by a zone of crushed greenstone with a maximum width of about 12 feet, in which the copper minerals are seen. Bornite, glance, chalcopyrite, and a small amount of native copper with malachite and a little red oxide as alteration products comprise the minerals associated with the fault.

White Dog and Mint claims.-Two claims on the west side of the more southerly fork of Peacock Creek have been partly prospected. The first of these, called the White Dog, is approximately 2,500 feet above Kotsina River. The country rock is greenstone and is cut by a fault plane striking $\mathrm{N} .40^{\circ} \mathrm{E}$. and dipping steeply westward. There is a crushed zone of rock along the fault ranging from $3 \frac{1}{2}$ to $4 \frac{1}{2}$ feet in width. The walls are well defined, and clay seams show where the principal movements have taken place. An open cut 25 feet long has been made in the crushed rock. Chalcopyrite or copper-bearing pyrite is scattered through the crushed rock and clay seams and has strongly colored them with iron oxide. Green copper carbonate óccurs as a surface stain, but bornite and glance were not seen here. The fault is plainly marked along the steep mountain side for several hundred feet.

Two hundred feet above the White Dog, and a little to the north, is a claim called the Mint. A small fault with a strike of N. $15^{\circ} \mathrm{W}$. and a dip of $60^{\circ} \mathrm{W}$. cuts a grayish greenstone having amygdaloidal phases. The rock adjacent to the fault is broken and crushed, causing a zone with a thickness of 6 inches to 1 foot which, besides the greenstone, includes a little quartz and calcite accompanied by bornite and glance. Chalcopyrite was not observed, but a heavy stain of iron oxode seems to indicate that either this mineral or pyrite had formerly been present. There is a parallel fault 4 feet from this main fault, and both are cut perpendicularly by a third poorly defined fault having the same strike and carrying a little bornite. The main fault was traced for a distance of 500 feet.

Mountain claim.-The mountain claim is one of several on the north side of the east fork of Peacock Creek. It is about 2,600 feet above Kotsina River and consequently is at a greater elevation than the other claims described. In August almost no work had been done on it and only a few small stringers of copper sulphides were exposed.

SHOWER GULCH.

A small stream joining Kotsina River a short distance below the glacier in which its southern branch originates is called Shower Gulch from the waterfall near its lower end. Native copper is found near this fall in the amygdaloidal greenstone that forms the country 
rock. Copper oçcurs as thin leaves or films in fractures of the greenstone and as grains and small slugs in the greenstone and in some of the amygdules. It is in places associated with secondary quartz, filling irregularly shaped veins or cavities. Several claims have been staked on Shower Gulch, but little prospecting has been done.

SURPRISE CRIEEK.

Surprise Creek is a northerly tributary of Kotsina River and heads in the high mountain southeast of the lower end of Kluvesna Glacier. Most of its bed is cut in the diorite mass previously referred to, and in a rude way follows the contact between the diorite and the greenstone on the east. It has a small eastern tributary, Sunshine Creek, which lies mostly in the greenstones. Tin is reported to have been found in the diorite of Surprise Creek, but the specimens of the supposed tin-bearing rock examined contained no tin, and no reliable assay tests of the rock are known to the writers. All the copper prospects are in the greenstone east of Surprise Creek. They are the property of the Alaska Kotsina Copper Company.

Laddie claim.-Between Surprise and Sunshine creeks is a steep gulch running down from the north. On the west side of this gulch and nearly 3,000 feet above Kotsina River is the Laddie claim. A very close-grained grayish "greenstone" forms the country rock and is cut by a fault striking N. $20^{\circ}$ to $30^{\circ} \mathrm{E}$. and dipping about $45^{\circ} \mathrm{NW}$. Along the fault is a zone of crushed country rock ranging in width from 2 to 3 feet, in which is a quartz vein 18 inches thick. Besides quartz there is a small amount of calcite. The vein carries copper glance accompanied by a little bornite and chalcopyrite. In places the percentage of copper minerals in the vein is high, but they are not distributed uniformly through it. A line of prospect holes extends along the vein for a distance of 200 feet.

Sheehan claim.-At the Sheehan claim, 200 feet higher than the Laddie and a little farther east around the mountain side, the greenstone is cut by a fault striking N. $45^{\circ} \mathrm{E}$. and dipping $45^{\circ} \mathrm{NW}$. This fault resembles the Laddie fault in being accompanied by a zone of crushed rock, but the zone is here somewhat wider, ranging from 3 to 4 feet. A small quartz vein is exposed, in which the copper minerals are glance, bornite, and a little pyrite. The small veins of glance cutting the quartz are in places half an inch thick.

Hubbard claim.-About 300 feet east of the Sheehan claim and a little higher on the mountain the vein of the Hubbard is exposed in two open cuts. The vein is almost perpendicular and strikes N. $40^{\circ}$ E. In the more southerly open cut there is a vein of white quartz ranging in thickness from 4 to 8 feet and carrying the copper minerals, chalcocite, bornite, and chalcopyrite, which are named in the order of their abundance. A strongly marked fault with 3 inches 
of clay seam defines the north wall of the vein. Eight feet from the vein on the southeast is a second vein or lens of quartz 10 inches thick and also carrying chalcocite. Between the two veins is crushed greenstone. Nearly 200 feet to the northeast along the strike an open cut 40 feet long and 25 feet deep has been made across the vein. The fault is again seen along the north wall, but the single large quartz vein exposed in the other cut is here represented by many smaller veins of lenticular form up to 12 inches in thickness. Chalcocite and bornite are the copper minerals. Nearly 1,000 feet farther northeast a well-marked fault with a zone of sheared greenstone crosses the ridge between Kotsina River and the Hubbard claim and is said to extend as far as the glacier from which this branch of the Kotsina springs. There is little doubt that this fault is the continuation of that crossing the Hubbard claim.

KLUVESNA CREEK.

Kluvesna Creek and its tributary Fall Creek are the only streams besides Surprise Creek coming into Kotsina River from the north on which any prospecting or assessment work was done in the summer of 1907. Kluvesna Creek drains the main lobe of Kluvesna Glacier, and the smaller western fork known as Fall Creek originates in a minor lobe of the same ice mass coming down from the snow fields of Mount Wrangell. The valley floor is a broad gravel flat, and was once occupied by glacier ice, which has since retreated to its present position 7 miles from the river's mouth. The country rock is greenstone, except that the Chitistone limestone forms the top of the ridge west of the southern part of the river, and descends to the Kotsina River valley near its junction with the valley of Kluvesna Creek. Dikes of light-colored eruptive rock, mostly dioritic in character, cut the greenstones locally.

On the east side of Kluvesna Glacier and nearly three-fourths of a mile from its south end copper minerals have been found in the greenstone several hundred feet above the ice. Three open cuts show a light-colored rock-possibly altered greenstone-cut by irregularly branching quartz veins. The light-colored rock contains chalcocite and chalcopyrite scattered through it in specks rarely larger than a pin head. There are besides this small veins of chalcopyrite. The greenstone country rock locally contains small particles of chalcopyrite, a fact that may have some bearing on the origin of the richer copper sulphide ores.

West or a little southwest of the mouth of Fall Creek; and nearly 1,800 feet above it, is a short tunnel, which is the property of the Kotsina Mining Company. ${ }^{a}$ This tunnel is on the north side of a

a The writers have lately learned that the name Kotsina Mining Company is no longer in use. 
small gulch running down to Kluvesna Creek and is located at the contact of a fine-grained greenstone and a grayish amygdaloidal greenstone. The contact, which is parallel with several prominent fault planes cutting the country rock, strikes N. $35^{\circ}$ to $45^{\circ} \mathrm{W}$. and dips $50^{\circ} \mathrm{SW}$. The fine-grained greenstone is much shattered and requires timbering to make it stand in the tunnel. Native copper appears as small particles in the amygdaloidal greenstone, both in the apparently unaltered rock and in portions that have been partly leached. It is also associated with small quartz and calcite veins in the greenstone. At many places where native copper is found there is a little red copper oxide. Several pieces of native copper and quart\% weighing 20 or 30 pounds were piled on the dump, but nothing like them was seen in the tunnel or in the open cut above the tunnel.

On Fall Creek or its tributaries a number of small open cuts and short tunnels in which copper minerals were seen were examined. These small branches flow into Fall Creek from the west within the lower 2 miles of its course. Less than half a mile from the mouth of the most northerly branch there is a short tunnel on the south side of the stream driven along a north-south fault in amygdaloidal greenstone. The greenstone is crushed and contains small veins of quartz and calcite. A green stain of malachite appears on the surface, but within the crushed country rock both green and blue copper carbonates are found in a way that suggests them to be the alteration products of some earlier copper mineral deposited along the fault. Between the rock fragments along the fault there is in places a soft black carbonaceous filling with which the copper carbonates are mingled. Only a small amount of copper minerals is exposed by the tunnel.

South of this creek on the second tributary a short tunnel about 6 feet under cover was made along a perpendicular north-south fault plane in amygdaloidal greenstone. This tunnel is only a few feet above the creek and on its north side. The greenstone is cut by many small, light-colored, fine-grained, porphyritic dikes containing abundant grains or crystals of quartz. A very little bornite is associated with quartz veins in the greenstone.

Up the hill to the south and 375 feet above the short tunnel just mentioned is another tunnel 40 feet long, also in amygdaloidal greenstone. Here, too, the perpendicular north-south faulting is to be seen, and green copper stains appear on the surface of the fractured rock. The tunnel was driven to strike the supposed downward extension of an outcrop of greenstone, contaning native copper, exposed on the ledge 25 feet above the tunnel and about that distance to the south, but had not reached it. Bornite and copper carbonates in small amount were seen in a number of shallow open cuts a short distance southeast of this tunnel. 
COPPER CREEK.

Copper Creek is the westernmost tributary of Kotsina River on which prospecting was done last summer. It drains a portion of the ridge between Kotsina River and Elliott Creek and joins the Kotsina 2 miles below Kluvesna Creek. All the geologic formations already named are present in the upper part of the basin-the Nikolai greenstone, Chitistone limestone, Triassic shales, and Kennicott formation. Their relations, however, are not simply those due to folding, for extensive faulting has accompanied the folding.

There are two principal branches of Copper Creek, but the western branch also forks at a point about $2 \frac{1}{2}$ miles from Kotsina River. Near this fork the limestone-greenstone contact crosses the two branches in a northwest-southeast direction, and good exposures of the limestone are found between the branches as well as on each side of them. The greenstone, however, is not exposed on the slope from the fork to the limestone outcrops between the branches.

The workings of the Mullen claim are between the branches, about 1,000 feet from the point where they separate and 275 feet above their junction. Three open cuts have been made along the foot of a limestone cliff. The strike of the limestone at this place is difficult to determine accurately, but is nearly north and south. It dips $45^{\circ} \mathrm{W}$. In the northernmost open cut, which is 20 feet long and 10 feet in depth from front to back, a fault plane parallels the bedding and forms the west wall of the cut. The limestone is much broken, particularly near the fault, forming a zone of broken rock with a maximum width of 3 feet. In places the limestone is almost completely replaced by bornite and chalcopyrite. The best ore forms a poorly-defined vein, ranging in thickness from 12 to 18 inches, but does not outcrop on the surface. Azurite is more abundant than malachite where the copper minerals are oxidized, and in places the bornite is completely altered to azurite. Small calcite veins are numerous, especially in the brecciated rock near the fault, where the fragments have been cemented together with calcite. There are minor faults or joint planes in which a green copper stain is seen, but this appears to be derived from the main vein.

About 75 feet south is another open cut, where the fault planes are not prominent, but where the limestone is much jointed. Bornite occurs in isolated bunches in the limestone.

About 75 feet still farther south is a large open cut, and a shallow pit has been made. Several faults may be seen here, but the most prominent ones strike east and west and dip at a high angle to the south. The north-south faults are present, but are continuous for only short distances. Patches of crushed rotten rock stained with iron oxide and copper carbonate lie adjacent to the faults and joints. There are also small masses of high-grade bornite replacing the lime- 
stone and forming bunch deposits in the country rock. These deposits were probably connected by the joints and faults with the channels carrying the mineral solutions, but this is not evident at the surface. A little chalcopyrite and both malachite and azurite are present with the bornite. Malachite is the surface stain, but below the surface azurite is the alteration product of the copper minerals. The bornite is cut by many thin veins of azurite, and in places contains small cavities lined with iron oxide or, with azurite crystals. More work has been done in this place than in the first open cut, but less ore seems to have been taken out, if the amount piled near by is an indication.

ELLIOTT CREEK.

General description.-Elliott Creek (see fig. 2) is a tributary of Kotsina River, and joins it approximately 17 miles above the mouth of that stream, or 12.5 miles almost directly east of the Copper River crossing. It is reached by a trail which leaves the Kotsina trail at Willow Creek and crosses Kotsina River by a bridge about half a mile above the upper end of the canyon. This trail passes over the southwestern spur of Hubbard Peak and reaches an elevation of approximately 2,700 feet before the descent to Elliott Creek begins. A second trail used for the first time during the summer of 1907, leaves Elliott Creek about 6 miles above the mouth at Five Sheep Creek, and crossing the west end of the ridge south of the stream leads to the Nizina trail not far east of the new government bridge.

Elliott Creek is approximately 10 miles long, and throughout most of that distance flows in a direction about N. $30^{\circ}$ W., but makes a sharp southerly bend before joining Kotsina River. More than 2 miles of the lower portion is through a narrow rock-walled canyon, but the upper part, along which the claims extend for a distance of $4 \frac{1}{2}$ miles, lies in a narrow V-shaped valley. Between the upper cabin, situated about midway between the upper and lower ends of the claims, and the lower cabin, a distance of $2 \frac{1}{8}$ miles, the creek descends 759 feet, or approximately 360 feet per mile. Above the upper cabin this gradient increases as the head of the stream is approached. Elliott Creek is fed in large measure by melting snow, and although the stream is not large, it is capable of furnishing considerable power with the head available.

The lowest and the only commercially important rock formation exposed in Elliott Creek valley is the Nikolai greenstone. All the copper prospects so far discovered here are associated with this rock. The massive bluish-gray Chitistone limestone is conformably overlain in some places by black and gray Triassic shales and thinbedded limestones cut by light-gray porphyritic dikes and sills, and in other places is succeeded unconformably by coarse conglomerate of the Kennicott formation. 


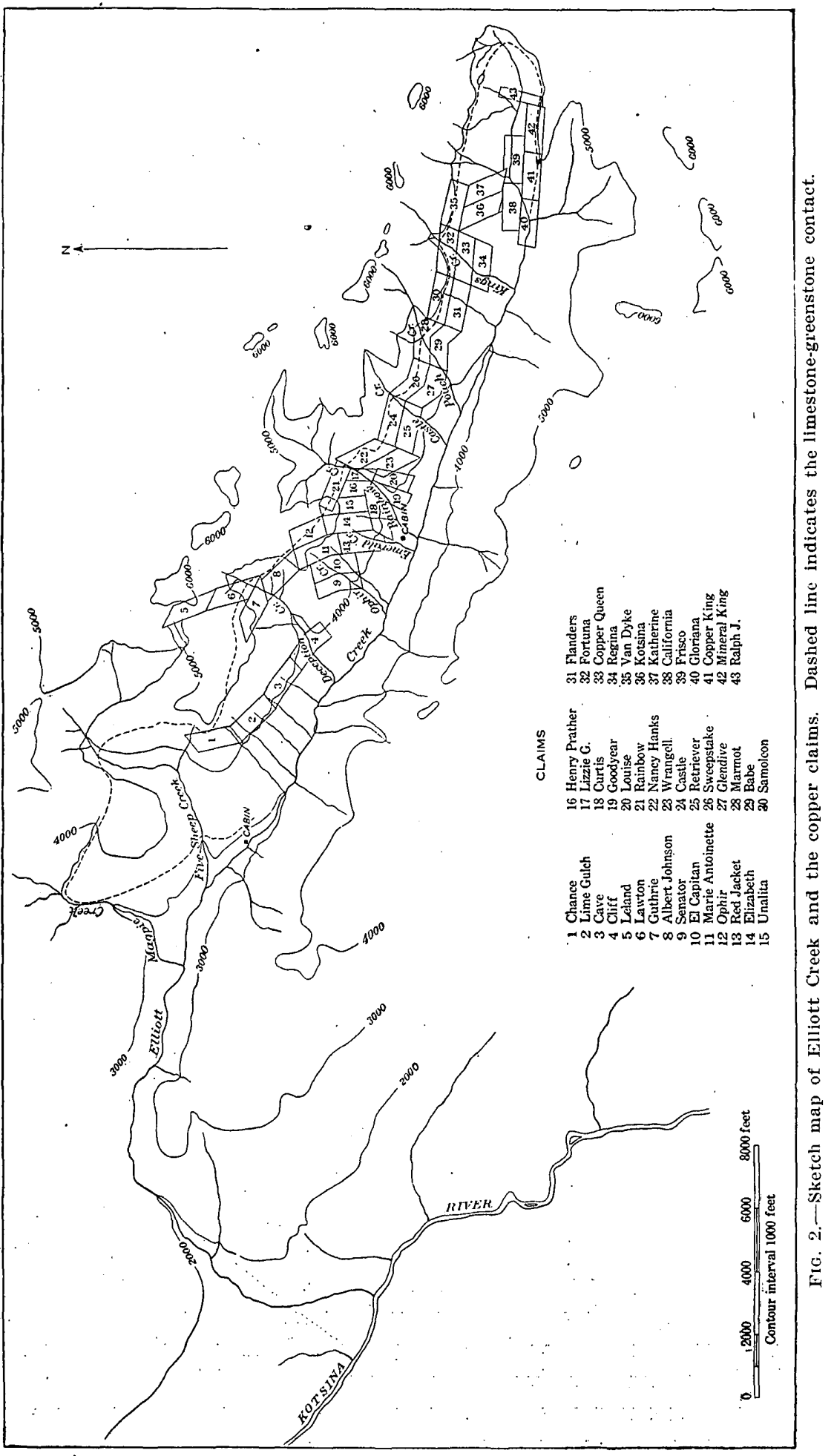


In an ascent of Elliott Creek the greenstone and overlying limestone appear for the first time on Magpie Creek and continue eastward from that locality to the head of the valley. These two rock formations form a great anticline (fig. 3), whose axis is approximately parallel with the course of Elliott Creek. It pitches under the younger rocks at the eastern and western ends and dips into the ridges on each side of the creek (Pl. VII, B). North of Elliott Creek and at its upper end the Chitistone limestone forms a very prominent topographic feature. With the exception of the Copper King and Mineral King the claims described are on the north side of Elliott Creek and all but 8 are owned by the Hubbard Elliott Copper Mines Development Company. The description of the claims is given in the order of their location from east to west.

Copper King and Mineral King claims.-The Copper King and Mineral King claims, often spoken of as "the Kings," are the most easterly on Elliott Creek. They are located along the limestonegreenstone contact at an elevation of over 4,000 feet above the sea.

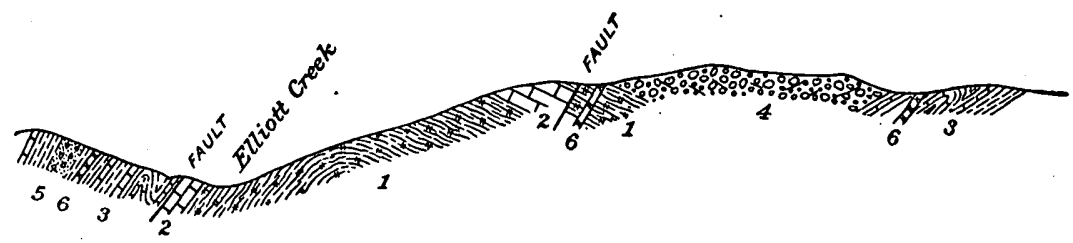

Fig. 3.-Cross section (somewhat diagrammatic) of the Elliott Creek anticline. 1, Nikolai greenstone; 2, Chitistone limestone; 3, contorted Triassic shales and limestones; 4 , Kennicott formation ; 5 , tuffs and shales ; 6 , porphyritic dikes.

On the Copper King claim there is an open cut in the greenstone a little more than 100 feet below the base of the limestone cliff, 1,390 feet above the upper cabin. 'The copper minerals are found along a shear zone in the greenstone. Bornite is the principal copper ore, and is seen along fractures and between them replacing the country rock. Calcite veins are not so numerous as might be expected near the limestone contact. The shear zone, which, as far as can be determined at this exposure, runs parallel with the base of the limestone, striking N. $60^{\circ}$ to $70^{\circ} \mathrm{E}$. and dipping to the south, is mineralized for a thickness of about 10 feet, though the copper-bearing solutions have penetrated the country rock for a greater distance, as is shown by a slight alteration of the greenstone. There is some pyrite in the ore, and besides malachite a blue coating of copper sulphate appears in protected places. This open cut is reached by climbing over a steep rock slide.

The two open cuts on the Mineral King are reached by another hard climb over a steep snow-covered talus slope. These cuts are about 800 feet northeast of the 'cut in the Copper King. The lower one was filled with snow at the time they were visited, but the ore 
piled up at one side consisted of bornite replacing greenstone. The second cut, 50 feet higher and about 100 feet farther west, is almost at the same elevation as the Copper King cut. The ore was found on the steep face of the cliff and consists of chalcocite, with a small amount of bornite replacing the greenstone along a fault or shear zone. Numerous close perpendicular joints running approximately $\mathrm{N} .60^{\circ} \mathrm{E}$. cut the greenstone, and there are a number of fault planes which strike N. $35^{\circ} \mathrm{E}$. and $\operatorname{dip} 30^{\circ} \mathrm{S}$. The trend of the disturbed zone is the same as that of the faults mentioned. The best ore has a thickness of about 6 feet and is traced for a distance of 25 to 30 feet along the strike, although the boundaries and extent of the ore body are somewhat indefinite. On the south, however, a fault plane makes a fairly well-defined wall. There is some rich ore at this exposure, but the development work is not yet sufficient to determine whether or not the ore body has any considerable extent.

Claim at the head of Queen Creek.-On the claim at the head of Queen Creek a small open cut has been made in the greenstone about 50 feet below the base of the limestone and shows small veins of calcite and a little quartz containing copper.

Van Dyke claim.-Two open cuts on the Van Dyke claim were visited, one 15 and the other 25 feet below the base of the limestone. The greenstone is stained with the oxidation products of iron and copper and contains also a small amount of pyrite, but the cut shows very little of the copper minerals.

Copper Queen claim.-The open cut on the Copper Queen claim is about 50 feet west of Kings Creek. It has an elevation of 905 feet above the upper cabin. The cut is nearly filled by the caving of the bank above, so that the face of the greenstone was not exposed. A large mass of the rock, however, which lay at one end was filled with a great number of tiny intersecting veins of iron and copper sulphide, either pyrite and chalcopyrite or, more probably, copper-bearing pyrite. The greenstone fragments were covered with the green copper coating.

Marmot claim.-A large open cut has been made on the Marmot claim at the base of the limestone between 200 and 300 feet west of Pouch Creek. The greenstone is much broken, and slicken-sided surfaces are numerous. The most prominent fault planes strike approximately N. $60^{\circ} \mathrm{W}$. and are nearly perpendicular. Small calcite veins carrying a small amount of copper-bearing pyrite occur along some of the openings. A malachite coating was seen in the greenstone, but is not prominent along the main fault planes. Bornite was not observed.

Louise claim.-The Louise open cut is on the east side of Rainbow Creek and 50 feet above it, or 390 feet above the upper cabin. The country rock is greenstone and is cut by faults and joints, Slicken- 
sided surfaces.are common. The best developed fault planes strike about N. $20^{\circ} \mathrm{W}$. and $\operatorname{dip} 45^{\circ}$ to $50^{\circ} \mathrm{W}$. Small calcite veins, having a thickness in general not greater than 2 inches and containing a little quartz, cross the country rock in all directions. Such veins are more numerous here than in most of the other workings examined. Bornite and chalcopyrite are the copper minerals present, and of the two bornite is the more abundant. They appear in the calcite veins and disseminated through the greenstone. The ore is best developed, however, in the calcite veins and the greenstone adjacent, to these. It is difficult to give any definite statement of the thickness of the mineralized zone. The ore extends parallel with the creek for a distance of about 30 feet horizontally.

Above the cut on the steep hill slope green copper stains can be traced for a distance of 150 or perhaps 200 feet. Such an exposure as this may be the surface indication of an ore shoot, but the rich ore can not be traced for any considerable distance on the surface, usually not more than 25 feet and rarely as much as 50 feet.

Lizzie G. claim.-The open cut of the Lizzie G. claim is in the bed of Rainbow Creek only a short distance from the Louise. The greenstone at this place is sheared and plicated, but many of the resulting openings have been filled by infiltration of quartz and calcite. Quartz veins reach a thickness of 2 inches and carry considerable chalcopyrite. Calcite filling is, however, the more abundant, and in places the rock consists of about equal amounts of sheared greenstone and calcite similar to the knotty masses of schist and quartz seen in many regions where metamorphism has been greater than in this area. These calcite-greenstone veins, if such they may be called, carry a considerable amount of bornite and chalcopyrite and make a fineappearing copper ore, but the open cut does not show how great a quantity may be present.

Goodyear and Henry Prather claims.-Directly opposite the Louise open cut, about 40 feet west of Rainbow Creek and 340 feet higher than the upper cabin, an open cut has been made in the claim known as the Goodyear. The amygdaloidal greenstone is cut by faults and is much jointed. The most prominent of these faults strike north and south and dip about $40^{\circ} \mathrm{W}$. Another set of less well-developed faults has a more easterly strike and a lower dip to the northwest. Between two of the north-south faults is a mass of rock lighter in color than the greenstone outside the faults. This lighter rock is sheared or sheeted parallel with the faults and is filled with a great number of thin calcite veins containing chalcopyrite or copper-bearing pyrite and bornite, somewhat like the leaves of a book made of coarse paper. In the lower part of the cut this ore body is between 4 and 5 feet thick, and forms a lenticular mass about 20 feet long bounded by two north-south faults and a northeast fault. The 
upper north-south fault is not continuous, but the lower foot-wall fault extends to the north for some distance. On the south this body of ore is much crushed and is filled with iron oxide. It can not be traced farther in that direction than the limit of the cut. Besides the thin veins of copper minerals in the sheeted rock there are small veins of calcite and ore throughout the mass.

Along the strike a short distance to the north, and a few :feet higher, the light-colored, copper-bearing rock reappears, but the upper boundary of the mass is the fault which forms the lower boundary of the lower body. The ore body has a maximum thickness here of not less than 8 feet. An irregular branching calcite vein containing small horses of the light rock or main ore body reaches a thickness of 14 inches and contains chalcopyrite and bornite. This body of ore continues for a distance of 50 or 60 feet toward the north. These two bodies are portions of a single ore body included between two north-south faults and cut by later faulting. (See fig. 4.)

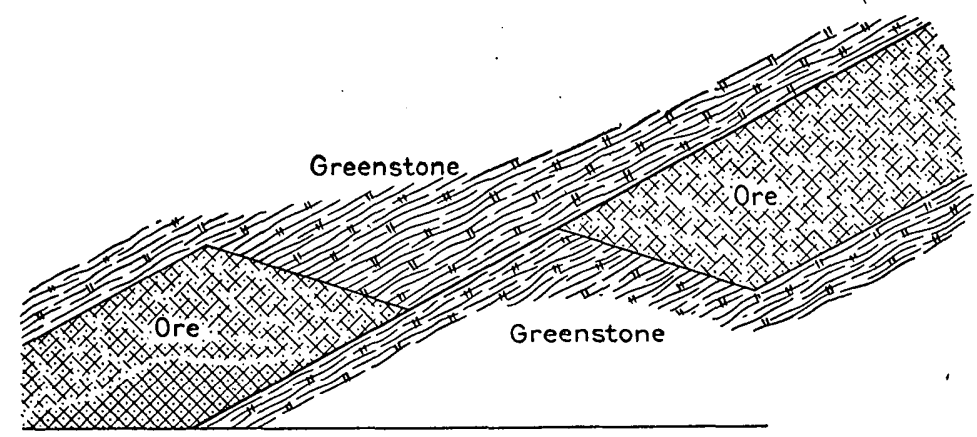

FIG. 4.-Diagram showing the faulted portions of the Goodyear claim, Elliott Creek.

Almost directly above the Goodyear on the hill slope to the west and not more than 100 feet away is the open cut of the Henry Prather. ${ }^{*}$ Here a north-south fault dips $60^{\circ} \mathrm{W}$. and is intersected by two parallel faults striking N. $40^{\circ}$ E. and dipping $30^{\circ}$ to $35^{\circ} \mathrm{W}$. These faults inclose a lenticular mass of rock 30 feet long and 5 . feet wide (Pl. IX, $B$ ), whose weathered surface is lighter in color than the inclosing greenstone and which is similar in all respects to the ore body of the Goodyear. This lighter colored rock is impregnated in a similar manner with copper sulphides, and through it runs a vein of coarsely crystalline calcite carrying chalcopyrite and bornite, which are very rich in places. The calcite vein has an irregular thickness ranging from 8 to 12 inches, and in two places is offset by small faults to a distance of 10 inches.

The main north-south fault may be traced north for about 75 feet, and shows much green stain and some sulphides, but the large calcite vein and main ore body end, apparently having been faulted 
off. Almost 50 feet from the ore body the large fault is intersected by a northeast fault. This also shows copper stain, and both contain small calcite veins with the sulphides.

Although no direct proof was obtained the similarity in character and appearance of these two ore bodies of the Goodyear and Henry Prather indicate that they are faulted portions of one mass.

Elizabeth claim.-The Elizabeth claim lies north of the upper cabin, and has received more attention in the way of development work than any other claim on the creek. This work consists of a tunnel and one or two open cuts. The tunnel is located in a narrow gulch a little more than 1,000 feet above the cabin. It has been driven into the greenstone in a northeasterly direction for 250 feet; and some ore has been uncovered, but it is not believed that the main ore body which outcrops on the hill above has been reached, and the work is to be continued. About 75 feet from the entrance the first copper appears in some lenticular veins of calcite and quartz, but there is only a small amount of this. In the face of the tunnel the greenstone is impregnated with bornite and chalcopyrite. Small veins of calcite also are present and carry the copper minerals. These small veins follow joint and slip planes in the greenstone and are rarely over half an inch thick. There is no well-defined master vein; the mineral waters appear to have followed a zone of fracture and faulting running, as closely as it is possible to determine at the tunnel face, in a nearly north-south direction. The greenstone has undergone considerable movement and slickensided surfaces are numerous. If the slip planes and joints follow any. definite general direction, this direction could not be determined. At present the tunnel does not reveal the thickness of the ore-bearing zone, nor even its direction with certainty.

In the gulch directly above the tunnel to the north, and about 100 feet higher, is an open cut exposing the copper-bearing fault zone, which the tunnel is expected to cut. The greenstone is much shattered, and shows a number of fault planes the most prominent of which range in strike from N. $10^{\circ} \mathrm{W}$. to N. $30^{\circ} \mathrm{W}$. Movement along some of these planes has been very marked, and the rock is greatly crushed. Bornite and chalcopyrite are present in small calcite veins and also impregnating the greenstone in and adjacent to the fault zone. The green stain due to oxidation is prominent here, as it is in all places where the copper minerals occur, and makes it possible to trace the copper-bearing zone from the open cut in a direction $\mathrm{N} .12^{\circ} \mathrm{W}$. for several hundred feet up the hill, where several other small open cuts have been made.

Marie Antoinette claim.-Copper minerals are exposed in the Marie Antoinette claim in two open cuts on the top of a narrow ridge adjoining the Elizabeth claim on the northwest. These cuts 
are within less than 100 feet of each other, and show shattered greenstone stained with the oxidation products of iron and copper. There are a number of faults which strike. in different directions, and in the open cut on the west brow of the ridge a crushed vein of variable thickness, consisting of calcite and a small amount of quartz, is exposed. The greenstone also contains veinlets of calcite, which follow joint or slip planes and carry the copper and iron sulphides. The larger vein strikes approximately $\mathrm{N} .30^{\circ}$ W., a direction which would take it somewhat to the south of the other open cut. Near it a small perpendicular dike of fine-grained diorite from 2 to $2 \frac{1}{2}$ feet thick cuts the greenstone.

Albert Johnson claim.-The Albert Johnson claim and the Guthrie claim described below adjoin each other end to end and lie parallel to and slightly below the greenstone-limestone contact. Deception Creek crosses their common end line at an angle of about $45^{\circ}$. Some open-cut work has been done, and a tunnel has been driven on the Albert Johnson about 100 feet east of Deception Creek. The tunnel is 30 feet under cover and is not over 150 feet below the base of the Chitistone limestone exposed to the north in the creek.

Small, nearly horizontal faults cut the greenstone, and the rock is otherwise broken by joints, giving it a blocky character. Calcite veins are present but not abundant. Copper ore is exposed in the tunnel and in the open cuts. When a piece of the copper-bearing greenstone is broken, bornite and chalcopyrite are found to be the copper minerals, the bornite predominating. The fault zone in which the copper sulphides occur can be traced by the green stain in a nearly horizontal plane almost around to the Guthrie tunnel, so that these two appear to form parts of one ore deposit.

Guthrie claim.-The tunnel of the Guthrie claim is on the hill slope west of Deception Creek, directly opposite the Albert Johnson tunnel and about 200 feet from it but 10 or 15 feet higher. Above the tunnel for a distance of 40 or 50 feet the surface of the country rock has been cleaned off, exposing small veins of calcite in shattered greenstone; these veins carry the sulphides bornite and chalcopyrite. The freshly broken greenstone adjacent to these small veins is also seen to be impregnated with the sulphides. There is no well-defined vein, but the jointing or faulting has permitted the mineral-bearing waters to circulate through a shattered zone in the greenstone. The tunnel is not more than 100 feet below the base of the heavy limestone as it is exposed in the creek to the north, which would account for the considerable amount of calcite present in the greenstone.

Leland and Lawton claims.-The Leland and Lawton claims are located in the saddle between the heads of Five Sheep and Deception creeks, which here has an elevation of more than 2,500 feet above the lower cabin. They lie north of the main body of the Chitistone 
limestone, whose scarp forms the prominent cliff on the southern brow of the spur to the south. This unusual location apparently above the limestone is due to faulting, which brings the greenstone up against the Kennicott conglomerate or rather against the large porphyritic dike which here separates these two formations. On the Lawton claim a fault which strikes $\mathrm{N}$. $30^{\circ} \mathrm{W}$. and dips $50^{\circ}$ to $60^{\circ} \mathrm{S}$. is seen between the greenstone on the south and the porphyry dike on the north. The dike here shows a thickness of 30 to 35 feet. Several open cuts have been made in the greenstone and show small : amounts of pyrite and chalcopyrite impregnating the rock adjacent to joint or fault planes. Green copper stain and also copper sulphate were seen in a number of other places. The copper minerals where observed were all within a few feet of the porphyry dike, but any other relation between the two was not evident.

Cliff claim.-The Cliff claim is on the west side of Deception Creek. Two open cuts have been made at an elevation of 600 feet above the mouth of this stream. The greenstone is cut by numerous fault planes, and slickensided surfaces are frequently seen, but perhaps the most prominent of the planes of movement strike nearly east and west and dip about $45^{\circ} \mathrm{N}$. The green copper carbonate and the oxide of iron stain the greenstone. Small amounts of the copper sulphides also are exposed along joint planes, but no considerable exposure of ore has been made.

Chance claim.- The Chance is the most westerly of the patented claims and includes the prominent point of the limestone cliff which is seen on entering the valley. A small open cut only a few feet below the base of the limestone shows the green copper stain and a little bornite in the greenstone.

\section{KUSKULANA RIVER BASIN.}

GENFRAT, DESCRIPTION.

Kuskulana River receives its greatest supply of water from Kuskulana Glacier, an ice stream made up by the union of four principal branches coming down from the southwest side of Mount Blackburn. The river is a little over 21 miles long, and in the upper half passes through a broad gravel-floored glacial valley between high, rugged mountains. After leaving the mountains it flows for more than 10 miles, most of the way in a narrow rock-walled canyon, across the broad valley of Chitina River and joins that stream 10 miles above Copper River. Strelna Creek is the largest tributary of Kuskulana River. It rises in the mountains about the head of Elliott Creek and joins the Kuskulana 3 miles from Chitina River, thus having a length of 12 miles.

Most of the copper prospects are in the vicinity of Kuskulana Glacier, where the Nikolai greenstone and Chitistone limestone are 
well exposed. There are, besides these two formations, some rocks of doubtful identity in the vicinity of Nugget Creek, a western tributary joining Kuskulana River just below the glacier. These rocks are probably the same as some at the head of Kotsina River which have been included in the Nikolai greenstone, but may be older. Triassic shales and limestones are well developed east of the Kuskulana and are also represented in a small area west of it.

The best-known copper properties of this area are on Nugget Creek, but there are other prospects on one or two neighboring streams tributary to the main river on the west side and in the vicinity of the glacier on the east side, as well as on Slatka and Trail creeks. There are also a few prospects on the head of Strelna Creek.

NUGGET CREEK.

General outline.-Nugget Creek drains the southeast side of the mountain mass whose northwest side is drained by Peacock, Roaring, and Rock creeks of the Kotsina basin. Several of its branches are fed by small glaciers. The stream is about 6 miles long and joins Kuskulana River less than a mile below the glacier.

The country rock includes amygdaloidal greenstones and other greenish rocks, which differ somewhat in appearance from typical exposures of the Nikolai greenstone and might be separated from it on closer study. A small area of Chitistone limestone outcrops on the mountain slope east of the upper part of Nugget Creek, and near it, along the creek bed, is a small exposure of gabbro.

Most of the copper prospects, of which there are a considerable number, are situated in the lower or southern part of Nugget Creek valley. Collectively they constitute the Alaska Consolidated Copper Company's properties, only a part of which were examined by the writers. The claims on which most work has been done are located on the small rounded hill between the lower end of Nugget Creek and Kuskulana Glacier. It was not possible in the short time available to visit any other properties than those on this hill, so that no description of claims in the Nugget Creek valley north of the hill or west of the stream can be given. A good trail leads from the creek's mouth to the camp, where several very comfortable cabins have been built.

Valdez claim.-On the south slope of the rounded hill referred to above is a claim called the Valdez. It is crossed by a fault or a set of parallel vertical faults, running N. $65^{\circ}$ E., along which the ore is deposited. The continuation of the fault or faults for a distance of several hundred feet is shown by a line of test pits, but how much farther they extend was not learned. A tunnel run in toward the north and 30 feet under cover gives a cross section of the deposit. At the mouth of the tunnel is greenstone separated by a fault from a large calcite vein on the north. The calcite vein has a width of 24 feet, as meas- 
ured along the tunnel wall. This wall, however, is not exactly perpendicular to the course of the faults: After passing through the calcite vein the tunnel penetrates a close-grained, dark-gray rock, possibly one phase of the greenstone series, for a distance of 5 feet. This latter rock and the vein are separated by a fault, along which is a seam of blue and yellow clay, ranging from 2 to 3 inches in thickness and containing small crystals of chalcopyrite. All of the calcite vein as exposed in the tunnel is ore. Bornite is the principal copper mineral, and is accompanied by chalcopyrite in minor amount. Movement has taken place along both faults since the ore was deposited, and the country rock, as well as the vein matter, is jointed and crushed. The greenstone is sheeted parallel to the fault, but the harder, close-grained rock in the face of the tunnel was more resistant and broke in angular blocks. The calcite vein is also much broken and in places granulated.

A prospect hole or crosscut a short distance northeast of the tunnel did not expose the vein, but 300 feet still farther to the northeast an open cut shows greenstone faulted against a light-colored rock, consisting chiefly of calcite and quartz, much shattered and impregnated with bornite and chalcopyrite.

Thirty feet to the southwest along the vein from the tunnel mouth is a shaft which in August, 1907, was partly filled with water, but was said to be 30 feet deep. The shaft is sunk in the vein matter, but here the vein has a thickness of only 8 or 9 feet. On the north side is greenstone, much sheared, and containing thin calcite veins accompanied by bornite. It is not evident from the exposures why the position of the greenstone with reference to the calcite vein is here reversed. The ore is similar to that in the tunnel. No traces of the vein or fault were seen on the grassy hill slope southwest of the shaft, nor were they expected, since no test pits had been dug and the country rock was not exposed.

One Girl claim.-The One Girl claim is on the west slope of the hill between Nugget Creek and the lower end of Kuskulana Glacier. A tunnel called the "mud tunnel" has been driven on the south side of a small gulch and extends into the hill for 100 feet in a direction $\mathrm{S}$. $75^{\circ} \mathrm{W}$. Of this tunnel 91 feet is in frozen slide rock, and is reported to have caved in sometime during the early fall. The remaining 9 feet of the tunnel is in amygdaloidal greenstone, the cavity fillings being calcite. No ore was observed in the face, but the tunnel had not been extended far enough to encounter the mineralized body of rock seen on the hill nearly 300 feet higher than the tunnel, toward the southeast. This "lead" is amygdaloidal greenstone country rock impregnated with fine particles or grains of chalcocite in association with small calcite veins and epidote. Several open cuts extending along a line from southwest to northeast show the same copper-bear- 
ing greenstone, but no work has been done to indicate the width of the zone, or any of its other dimensions. This ore, if the copper content is sufficient to warrant the use of the term under the conditions prevailing in Alaska, is similar in many respects to that of the Copper Queen claim north of the Nugget Creek camp.

Nugget Creek received its name from the large mass of native copper found in the creek bed a short distance above the camp. This nugget is estimated to weigh between 2 and 3 tons, and is too heavy to be removed economically by any means of transportation now available. It is 7 feet in its greatest dimension, 3 feet 2 inches wide in the middle, and has a maximum thickness of 12 inches, but the average thickness is probably less than 6 inches. Many smaller nuggets, ranging in size from shot to pieces of several ounces or pounds, are found in the gravels of the creek, but their bed-rock source has never been discovered.

STRELNA CREEK.

The copper prospects of Strelna Creek are of interest chiefly as showing a close relation between copper deposition and the limestonegreenstone contact. The Chitistone limestone forms numerous cliffs in the upper part of the creek, particularly on the branch leading to the Elliott Creek pass.

About a mile southeast of the Elliott Creek pass a small area of Chitistone limestone caps the greenstone of the ridge south of Strelna Creek. The north contact of the two formations is here a fault contact. From 6 to 8 feet of the decomposed greenstone along the fault is heavily mineralized with pyrite, weathering to brown iron oxide. Along with the pyrite is a little copper, as is shown by the green stain of malachite. In the heavy overlying limestone, but not over 10 to 20 feet above the contact, thin veins of copper-bearing pyrite were seen in the limestone. Stringers and small bunches of ore are not uncommon in the underlying greenstone at various places on the creek.

\section{LAKINA RIVER.}

Lakina River rises in an area of glacial drainage of minor importance lying between the much more extensive basins of the Kuskulana Glacier on the west and the Kennicott Glacier on the east. The Lakina is not as large or as turbulent a glacial stream as the Kuskulana or the Kennicott.

The trail regularly traveled through this region reaches Lakina River about 6 or 7 miles below the lower ends of the two glaciers from which the river emerges. This portion of the valley of the Lakina differs somewhat from the valleys of Kuskulana and Kennicott rivers where they flow from their glacial sources in that it has a more basin-like expansion in its lower half. This basin-like expanse, which is about 2 miles wide along the trail and gradually narrows 
into a mountain gorge valley one-half mile wide toward the head of the river as the glaciers are approached, is floored with deposits of gravel, sand, and mud.

In an ascent of Lakina River from the main trail, the first bed rock to present itself along the margins of the flat gravel floor of the valley is the Nikolai greenstone. This rock appears on both sides of the valley where the valley begins to become more restricted, about 3 miles below the glaciers, and rises in steep mountain slopes on both sides. Above the greenstone the Chitistone limestone presents its characteristic cliff-like faces, and above the Chitistone limestone a series of shales and thin-bedded limestones on the east side of the valley forms bare slopes that are also present, though not so evident, on the heights west of the river.

The camps of two prospecting parties are located 'within a few hundred yards of each other on the west side of the Lakina about a mile below the glaciers from which the river flows. The copper prospects occur at comparatively low elevations above the river in the greenstones that form the steep western side of the valley at this place.

The prospect farthest up the river is about 250 feet up the mountain side from the upper cabin. A short open cut, about 6 feet deep, has been made on a shear or minor fault plane that strikes N. $30^{\circ} \mathrm{W}$. and dips $70^{\circ} \mathrm{SW}$. into the country rock of amygdaloidal greenstone, which at this place is weathered to a reddish-brown color. The walls of this plane are separated at this opening for about 2 feet, and the space thus formed contains a filling of crushed and slickensided slabs and fragmental pieces of the country rock, the whole being cemented together by the deposition of quartz in the interstices. The quartz in one place is somewhat continuous along one of the walls for a few feet and has a thickness of from 1 to 2 inches. Most of the filling, however, is crushed country rock. A small amount of native copper: in the form of specks and scales occurs within this filling. The amygdaloidal greenstone country rock just north of this filled space is checked with thin veinlets of quart\% and contains some scattered chalcopyrite in specks and films. The narrowness of the opening makes it impossible to give any idea of the extent or amount of mineralization at this place.

The second prospect of this vicinity is similarly located on the lower slopes of the mountain side only a few hundred yards south of the one just described. At this locality the natural exposure of the rocks is good enough to exhibit the so-called pseudobedding that the Nikolai greenstone shows in many localities. Here this bedlike structure of the greenstones strikes N. $70^{\circ} \mathrm{E}$. and dips $45^{\circ} \mathrm{SE}$. Apparently there has been some shearing or movement along a major plane of pseudobedding or faulting as well as movements along joint 
or other pseudobedding planes parallel to the principal one. This is shown by clean block or slab spalling for a distance of 500 to 600 feet on the strike and dip above recorded. This well-exposed face extends up the mountain side to the west and above the camp in a diagonal direction. The surface of the exposure is a natural dip slope along the major pseudobedding plane, offset somewhat by parallel bedding or joint planes. Slickensided surfaces may be observed along the joints or planes, and a tendency toward plication, indicative of shearing movements, is present. A small stream flows down over the surface of this rock incline. Along the major pseudobedding plane at this locality there is a somewhat continuous sheet-like filling of rock that does not look very different from some phases of the country rock at this locality and elsewhere. This sheet-like filling ranges from 1 to 6 or 8 inches in thickness and, as the surface of the rock incline is now exposed, this material lies in patches as a veneer over the surface of the country rock. It does not appear to be so markedly siliceous as the filling in the prospect several hundred yards to the north. It is this filling that contains the native copper in specks, flakes, slugs, and nugget-like lumps. No pieces of native copper of large size were observed, the largest pieces seen being about 2 inches by one-half inch in area; the size of these, as they are exposed on the surface, is due to the flattening and spreading to which they have been subjected by the impact of material carried down over this steeply inclined rock surface by the stream. The surface exposure of this sheet of native copper-bearing material, which lies bare over an area of about 400 by 20 to 30 feet, has been well picked over for specimens, and most of the larger pieces of copper originally present have been removed. For this reason it is impossible to give an estimate of the quantity of native copper that a given volume of the sheet-like filling along this shear plane may have originally contained. No work has been done in opening up the locality to show how extensive or persistent the deposit may be in any direction, and there appears to be no evidence to justify an assumption that there is a mass of native copper-bearing rock 20 to 40 feet wide extending into the mountain in a direction perpendicular to the strike of the pseudobedding.

High up on the mountain side, 2,400 feet above and three-fourths of a mile west of the camps on the river, some surface stripping has been done that exposes a fault in shattered amygdaloidal greenstones. This fault strikes N. $15^{\circ}$ E. and dips $75^{\circ}$ W. The walls are 18 inches apart and the space is occupied by what appears to be a gouge of crushed country rock, the 6 inches of material adjacent to the hanging wall being essentially earthy and the remaining 12 inches on the foot wall being cemented by a quartz filling. Apparently just enough copper-bearing mineral matter is associated with this cemented 
gouge to stain the surface of the 18 inches exposed with green carbonate films. No other copper minerals seemed to be present, but some may be finely disseminated through the cementing material. A very little bornite in specks and stringers not over one-eighth inch thick was observed in a piece of loose material at this place.

\section{KENNICOTT RIVER BASIN.}

The summer trail that leads through the mountains east of Lakina River to the Kennicott Glacier follows the banks of the Lakina to Fohlin Creek, a tributary flowing from the north. The trail then ascends Fohlin Creek about 2 miles to its first large tributary from the east, locally known as Bear Creek, and continues up the valley of Bear Creek to Kennicott or Fourth of July Pass. From this mountain gap the trail descends Fourth of July Creek to the western margin of the Kennicott Glacier, down along which it continues to Kennicott River.

\section{HIDDEN CREEK.}

Hidden Creek is a tributary to Kennicott Glacier on its west side, about 4 miles northeast of the mouth of Fourth of July Creek. It presents a feature of lateral valley drainage that is unique in a way, yet also characteristic of many glacial valleys that are tributary to larger glacial valleys where the main ice stream still flows past and completely dams the mouth of the smaller valley. Considered by itself, the valley of Hidden Creek presents all the features of larger glacial valleys. The head of the valley comprises ample cirque basins for the accumulation of snow and its transformation into the ice of comparatively small glaciers that now exist at its head. These glaciers flow from their basins and terminate well down toward the valley level, but they do not extend into its flatter main portion. From them issue small streams that within a short distance join to form a creek of good size that flows down over the gravel-floored part of the valley. At its lower end the valley of Hidden Creek is completely dammed by the Kennicott Glacier, which ponds back the waters of the stream so as to form a lake which occupies the entire lower valley. This body of water is known as Icy Lake. It is one-half mile across and extends $1 \frac{1}{2}$ miles up the valley to a point where the gradually ascending gravel floor rises above its surface. This gravel floor continues as bare flats to the foot of the slopes of the cirque basins, from which the small steep glaciers occupying the head of the valley descend. The stream flowing over it from the glaciers at its head to the lake at its foot is about 2 miles long and has been well named Hidden Creek, as its existence is not to be suspected and it can not be seen until the valley is actually entered. About half a mile above Icy Lake on the 
south side of the valley a small stream that heads near Fourth of July Pass flows out of a steep mountain gorge. This stream is locally known as Glacier Creek.

The steep walls of both the north and south sides of the valley of Hidden Creek expose on the lower halves of their slopes the Nikolai greenstone, above which rise practically inaccessible cliffs of the massive Chitistone limestone. A number of lode claims have been located along the contact of the greenstone and overlying limestone, where in places a little evidence of copper mineralization is to be seen. Most of these locations were made in 1906, and during the summer of 1907 assessment work was performed on them with a view to prospecting the ground.

The Great Northern Development Company had in this neighborhood for part of the season a crew of men who expended most of their labor in making a trail to the valley by following along the steep mountain that bounds the western side of the Kennicott Glacier for a couple of miles south of Hidden Creek. This trail was not completed.

The only actual work on claims located in the Hidden Creek valley was done by the Valdez Exploration Company. This company packed its supplies with horses up a trail over the western lateral moraine of Kennicott Glacier to the Hidden Creek valley, thence by a hazardous route across the ice that dams that valley to the north side, and thence up the northern shore of Icy Lake to its head. The camp was located 500 feet above the bed of Hidden Creek on a small area of bench ground, about 4,100 feet above sea level, that lies in the fork formed by the junction of Hidden and Glacier creeks. During the summer season of 1907 five or six men were employed by the company in prospecting a group of 25 lode claims, more or less, some of which are located on the greenstone-limestone contact that extends along the south side of the Hidden Creek valley above Glacier Creek. About half a dozen claims extend from this group along the contact to the west and across the course of Glacier Creek into an area of greenstones. Another chain of claims has been located up the valley of Glacier Creek and across the divide at its head into the headwater drainage area of Fourth of July Creek.

Most of the work on Hidden Creek is on its south side, about a mile above the camp, and consists of open cuts in the greenstones about 300 to 400 feet below their contact with the overlying limestones. All the work done during 1907 was necessarily in the form of open cuts, because of the difficulty of getting supplies into the place, especially timber for tunnel work, necessitated by the condition of the rock. No timber of any kind grows near Hidden Creek. Five open cuts were seen on claim 3 at this locality, at an elevation of from 4,800 to 4,900 feet above sea level, in much-sheared greenstones, the 
shattered blocks and fragments of which are tightly keyed into one another. The displacements that the greenstones have undergone at this place have been severe enough to obscure the pseudobedded structure to a large extent. The mineralization through and between these keyed shattered blocks consists of irregular and disconnected stringers of bornite with lumps of the same mineral, some of which may weigh as much as 20 to 30 pounds. There is no continuity to the mineral deposits. They appear to be scattered erratically through the greenstones in an irregular zone for a width of 25 to 75 feet, and by far the greatest amount of this material is only shattered country rock.

GLACIER AND FOUR'TH OF JULY CRELKS.

Nebraska claim.-About three-fourths mile up Glacier Creek, at an elevation of approximately 4,800 feet above sea level, an open pit 8 feet square and 8 feet deep has been sunk, on what is called the Nebraska claim, in a shattered mass of the greenstone that forms a low knoll in the valley. This knoll appears to be a slide mass from the mountain side on the east. Green copper carbonate stains, specks of bornite, and one speck of chalcopyrite were observed in some of the pieces of rock that came from this pit, but nothing more was revealed. There is said to be a surface showing of chalcocite, upon which no work has been done, in the greenstones about 400 feet below the limestones on the southeast side of Glacier Creek opposite the camp.

Bekka and Eli claims.-Above the Nebraska claim the Chitistone limestone dips southward under thin-bedded limestones and shales. But the stratigraphic continuity of the rocks that occupy the headwater areas of Glacier and Fourth of July creeks is disturbed by a line of major faulting that passes in an east-west direction through the head of Fourth of July Creek. This fault throws the heavybedded Chitistone limestone to the surface again on the divide between Glacier and Fourth of July creeks, where it is exposed for a thickness of about 600 feet. There is probably a minor fault that passes across Glacier Creek north of and parallel to the major displacement on Fourth of July Creek. Over this faulted area the Bekka and Eli claims extend, crossing the divide to the head of Fourth of July Creek, where the major fault brings the thin-bedded limestones and shales against the greenstones. In the greenstones at the head of the creek, about 200 feet below the massive Chitistone limestone, is a bed of crystalline rock about 30 feet thick that has the attitude of a sill. Above the sill-like rock at this place is typical amygdaloidal greenstone that does not appear to be altered from its usual texture in any way. Along the contact between this crystalline rock and the overlying amygdaloidal greenstone are a few thin seams 
of chalcopyrite, and there are also specks of this mineral within the amygdaloid a few inches from the contact. Bornite occurs associated with this chalcopyrite in very small quantities, and the presence of a small amount of chalcocite is suspected from its occurrence in a piece of rock not in place picked up below.

BONANZA CREEK.

The Bonanza mine, on the most valuable known copper deposit of Chitina Valley, is situated at the head of Bonanza Creek, about $1 \frac{1}{2}$ miles east of Kennicott Glacier and 7 miles north of the glacier's southern extremity. It is the property of the Kennicott Mines Company, and is the only property visited during the season that gives promise of shipping ore in a commercial way in the near future. Two other groups of claims, known as the Jumbo and Independence groups, are situated in the vicinity and are owned by the same company.

Bonanza Creek is about 3 miles long and heads on the west side of the high mountain ridge running north and south between Kennicott Glacier and McCarthy Creek (Pl. VIII). Its general course is southwest. The company's main camp and office, however, are located at the mouth of National Creek, almost 4 miles by trail from the mine. A new trail, sufficiently wide for a wagon road, is nearly completed and leads from the lower camp to the upper one, and a second trail of easy grade and good width leads down the east side of the glacier to the Kennicott River crossing.

South of National Creek the high north-south ridge between the glacier and McCarthy Creek is made up of Triassic shales and limestones, intruded by large masses of a light-gray quartz porphyry. These Triassic rocks and the intrusive are separated by a great fault from the greenstone and overlying Chitistone limestone on the north. The strike of the limestone is northwest and southeast, and its dip averages between $25^{\circ}$ and $35^{\circ} \mathrm{NE}$. It therefore cuts diagonally across the main ridge and appears at the glacier's eastern edge, nearly 9 miles north of the head of Kennicott River. The limestone here has a thickness of more than 1,000 feet. Still farther northeast the Triassic shales conformably overlying the heavy limestone reappear, but they do not occur within the area of the copper-bearing rocks. Bonanza Creek and the other creeks where copper claims have been located lie wholly within the greenstone-limestone area.

The Bonanza mine (fig. 5) is situated on the west side of Bonanza Creek, on a spur running down to the southwest from the main ridge. This spur divides Bonanza Creek from a small south westward-flowing tributary heading just west of the mine, and is crossed by the greenstone-limestone boundary about one-half mile southwest of the main ridge. 'On the axis of the ridge this boundary has an elevation 


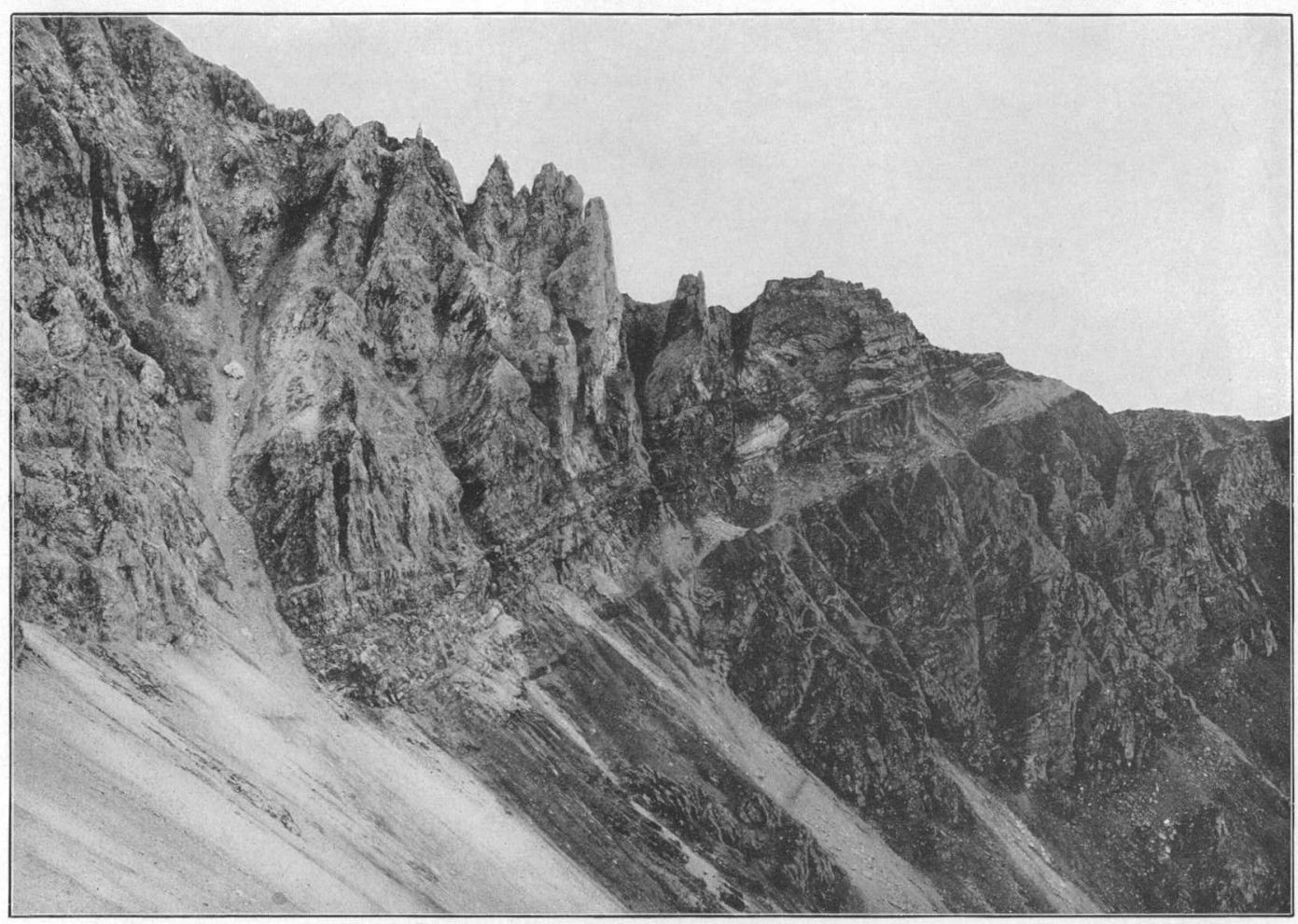

BONANZA MINE, FROM HORSESHOE TRAIL, 
of approximately 6,000 feet above sea level, or 3,800 feet above the mouth of National Creek, where the ore bins are to be built. To the southwest the spur is greenstone; to the northeast it is limestone, ris-

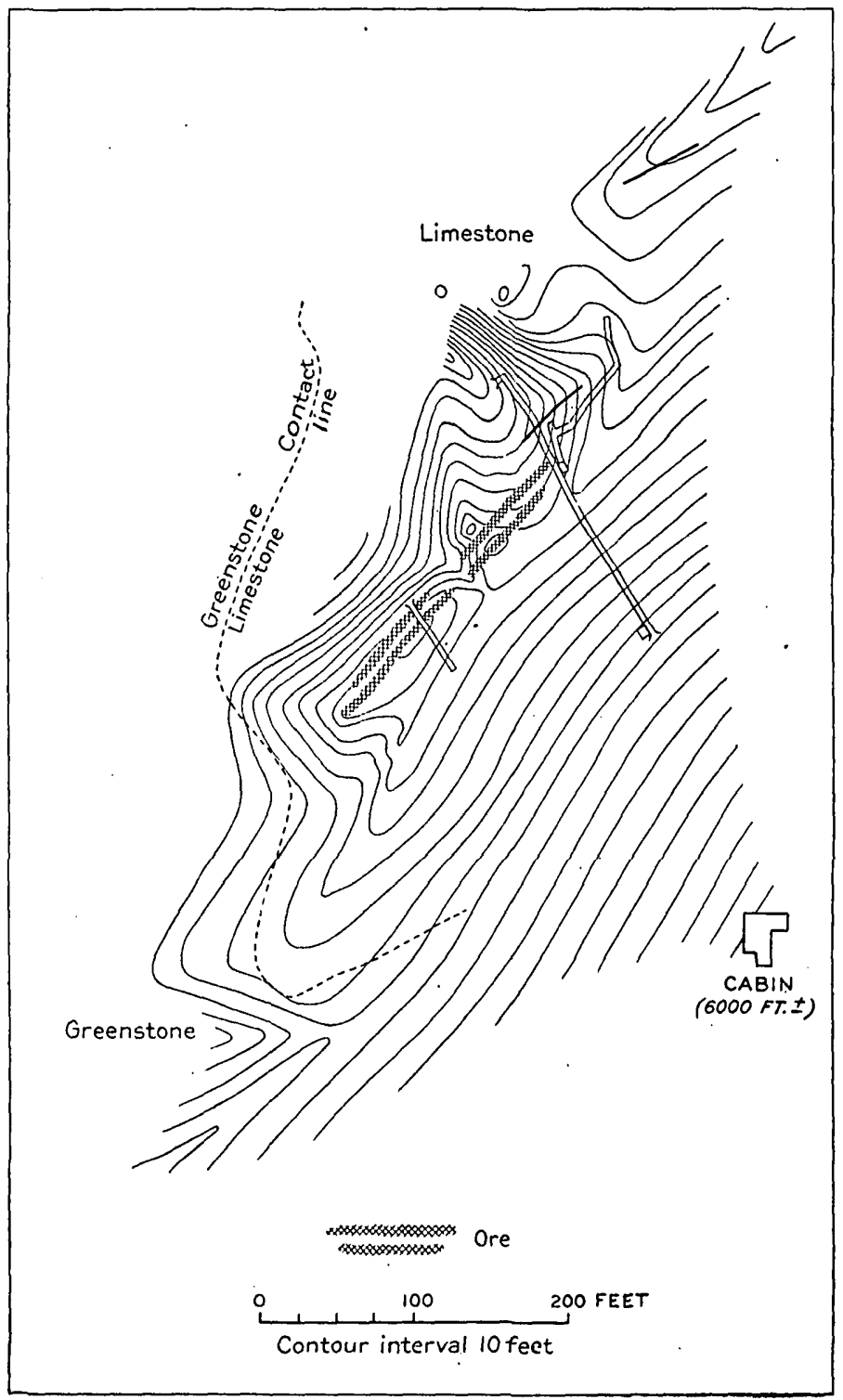

Fic. 5.-Sketch map of the Bonanza mine, showing the limestone-greenstone contact, the location of the rich ores of the surface, and the tunnels.

ing to an elevation more than 1,000 feet greater than that of the contact.

The greenstone immediately below the ore body is variable in texture and general appearance. Part of it is amygdaloidal, but 
porphyritic intrusive phases are also present. Amygdules are not confined to the upper part of a flow, but are present throughout from bottom to top. In some places they have been dissolved out on exposed surfaces, leaving a cellular rock that looks like a recent lava. Between the greenstone and overlying limestone there is a bed of green and red shale having a thickness of about 5 feet. This shale forms a narrow bench for a short distance along the northwest side of the ridge, but is everywhere covered with talus and is only found after a careful search. The base of the limestone consists of not less than 40 feet of coarse gray, slightly argillaceous rock, whose broken surface in places is covered with flattened cylindrical bodies that immediately suggest organic material of some kind, but a careful examination of the markings did not indicate such origin, and it is probable that they merely represent some peculiarity of fracture. Over this is a few feet of impure shaly limestone, which in turn is overlain by dark and light-gray massive beds which carry the ore bodies. At the mine the limestone dip is slightly variable, but averages about $22^{\circ}$ toward the northeast.

The limestone is broken by numerous faults and fracture planes, the most prominent of which äre nearly perpendicular and range in strike from N. $40^{\circ}$ E. to N. $70^{\circ}$ E. A minor set of fault planes, with about the same strike, dips steeply to the west. Another set runs. in a northwesterly direction, and in several places striations on slickensided surfaces or clay seams show that the movement was horizontal.

Fault planes with low dips, some of them nearly horizontal, are also present. None of the faults observed give evidence of much displacement, but together with the numerous joints they afforded an opportunity for mineral-bearing waters to enter the limestone. The principal fault planes-those running from northeast to southwest-form what may be described as a sheeted zone in the limestone. This zone has a width of 50 or 60 feet and extends through the shale bed into the greenstone below, but is less noticeable in the greenstone than in the limestone. A vertical displacement of 2 feet occurred in the limestone-greenstone contact along one of the fault planes in the shear zone and is the maximum displacement observed. This zone of fracture and slight displacement was not traced in a welldeveloped form for any considerable distance to the northeast, although the limestone exposures are on the whole very good, and one would expect to find it with little difficulty. ${ }^{a}$

The copper ores are chalcocite and azurite. The chalcocite is in veins or tabular masses of solid ore up to 5 or 6 feet in thickness, in large irregularly shaped bodies, and in stockworks in the brecciated limestone. Two principal veins of chalcocite are seen on the

a Since visiting this region the writers have been informed that the shear zone crosses to the McCarthy Creek side of the ridge northeast of the Bonanza mine 
surface. They stand almost perpendicularly, 12 to 15 feet apart, and strike $\mathrm{N} .41^{\circ} \mathrm{E}$., forming the comb of the sharp ridge, but crossing it at a slight angle, as the ridge at this place has a more nearly north-south direction than the veins. The veins do not extend down into the impure lower part of the limestone, but end abruptly and flatten out on reaching it. In places the precipitous northwest face of the ridge is plastered over with masses of solid chalcocite for a distance of 50 or 60 feet vertically below the top.

Azurite appears on the surface of the chalcocite and also as a lining of small vugs in the glance, but it is present chiefly as thin veins that form a network in the limestone and probably are due to the alteration of original chalcocite veins, for some of the azurite has an inner core of chalcocite. Azurite is more conspicuous than chalcocite in the northern 150 feet of the ore body, but chalcocite forms the great mass of the remainder. The ore bodies formed along the northeast-southwest faults of the northern part of the deposit are not the direct continuation of the large chalcocite veins at the south, but lie in nearly parallel veins which cut the ridge at a greater angle, their strike being about N. $60^{\circ}$ to $70^{\circ} \mathrm{E}$. The very rich ore can be traced on the surface for a distance of about 250 feet. It ends abruptly on the south in a nearly vertical limestone wall, but on the north gives place to the lower grade ores, consisting of small veins of azurite and chalcocite with scattered masses of chalcocite, some of them weighing several tons. This lower-grade ore shows on the surface for a distance of at least 150 feet northeast from the highgrade ores, and small scattered azurite veins extend still farther in that direction. 'The ore, as it shows on the surface, therefore, extends northeast and southwest along the strike for a distance of 400 feet. The thickness, however, is more indefinite, but the very rich ore, with its included limestone, as seen at the surface, has a width of approximately 25 feet, although the thickness of ore sufficiently rich to be mined may be greater.

A little chalcocite and less bornite is found in some of the shearing planes in the greenstone, but it does not extend far into the greenstone. The quantity is small and inconspicuous and might readily pass unobserved. A small amount of epidote is associated with it in places. The main shear zone in the greenstone cuts an older set of quartz-epidote veins, whose direction is about north-northwest. These quartz-epidote veins do not intersect the limestone. They reach a'maximum thickness of 1 foot and carry small amounts of chalcocite, bornite, and native copper.

Two crosscuts (fig. 5) have been driven in the ore body in a direction N. $33^{\circ} \mathrm{W}$. They are, therefore, not exactly perpendicular to it. The longer of these crosscuts starts on the east side of the ridge and 75 feet below its top. It is 180 feet in length and extends through 
to the west side of the ridge. The richest ore, consisting of large masses of chalcocite with some included limestone, is encountered at a distance of 90 feet from the tunnel's mouth and continues for a distance of $21 \frac{1}{2}$ feet, as measured in the roof. There are smaller bodies of chalcocite, however, for a distance of 10 or 15 feet on either side of the main ore body. About 115 feet from the entrance to the tunnel a winze 33 feet deep was sunk in the ore, and from the bottom a drift zigzags northward approximately 110 feet.

About 120 feet southwest of this tunnel is a parallel tunnel driven from the west side of the ridge and 50 feet lower than the little saddle above it on the north. This tunnel starts in a face of solid chalcocite and extends S. $33^{\circ}$ E. for 50 feet. The ore, which is chalcocite with a small amount of azurite, is exposed for 34 feet along the tunnel, but is interrupted by.horses of limestone. The remainder of the tunnel shows limestone cut by small azurite veins and in places containing a small amount of chalcocite.
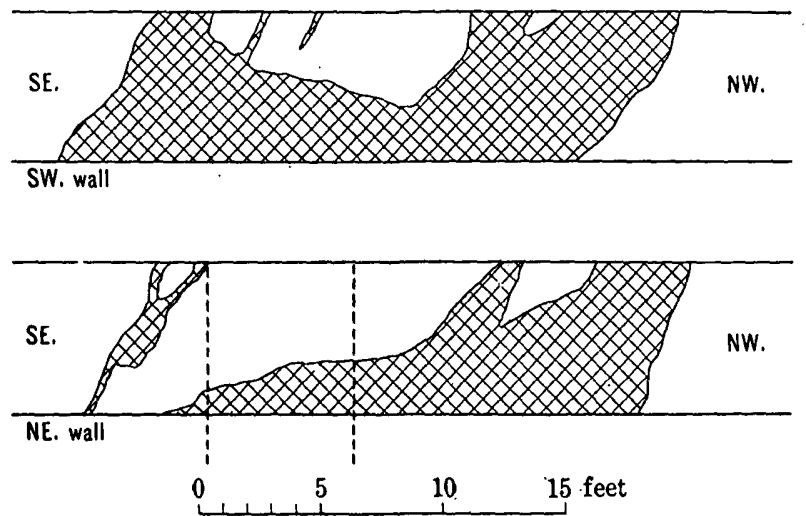

FIG. 6.-Sketch showing form of ore body exposed in the main or northern tunnel at the Bonanza mine.

A better conception of the form of the ore bodies can be obtained by an examination of figs. 5,6 , and 7 than can be given in a written description. The two main parallel surface veins afford only an imperfect idea of the deposit. Those two veins represent a total replacement of limestone along minor zones where shearing was most intense. The two tunnels show that not only is the limestone replaced along the main shear zone, but that mineralized waters followed minor fracture planes also, and thus yielded the low-lying ore bodies and great irregular masses seen underground. Between and around the large masses of chalcocite the limestone was shattered and filled with many small veins of ore, forming a stockwork that is most noticeable in the winze tunnel and on the surface northeast of the main ore body. As a rule the brittle chalcocite is very little fractured. The limestone, on the other hand, is greatly shattered 
and is filled with thin veins of calcite, which are older than the ore deposition. Open cavities in the fractured limestone have been filled with ice, and both the country rock and the talus on either side of this ridge are frozen all summer except for a few feet at the surface. The talus slopes below the ore body contain a large quantity of chalcocite resulting from weathering of the veins above and are a valuable source of copper.

It is a suggestive fact that, although the main shear zone of the Bonanza mine extends from the limestone through the thin shale bed into the greenstone below, the large chalcocite bodies, so far as can be determined on the surface, end abruptly at the top of the impure shaly beds forming the lower 50 or 60 feet of the limestone. Copper: minerals are associated with the shear zone in the greenstone, but only in small amount. Apparently the impure thin-bedded part of the limestone was a less favorable place for deposition than the purer

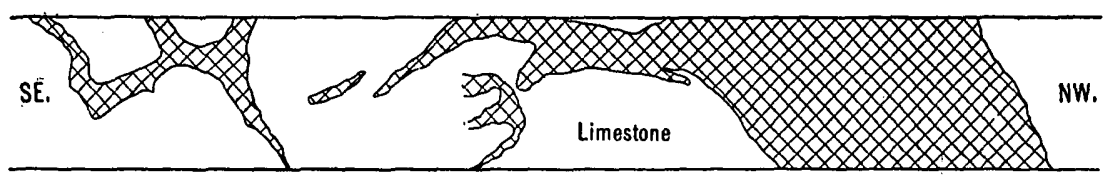

SW. wall

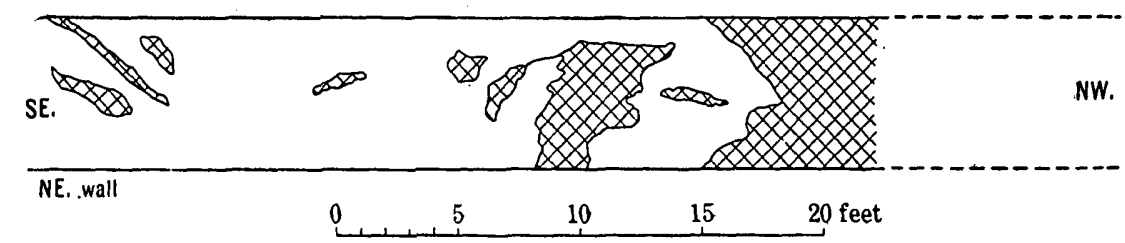

FIG. 7.-Sketch showing form of ore body exposed in the southern tunnel at the Bonanza mine.

massive beds above. This fact has a practical bearing on the quantity of ore present, for it is evident that if the same condition continues underground it limits the downward extension of chalcocite in the limestone. The continuation of the ore body to the northeast will probably be limited chiefly by the continuation of the shear zone in that direction. The exact conditions which determined the deposition of the Bonanza dre body are not known; possibly it was the presence of a shear zone favorable to circulation, but its occurrence together with that of the Jumbo and Erie chalcocite bodies to the northwest indicates that favorable conditions for deposition have been established in more than one place and offer encouragement for seeking other chalcocite bodies at the base of the Chitistone formation.

From the description that has been given it will be seen that there is little on the surface or in the tunnels by which to determine that the ore body has a greater extension from southwest to northeast than 
about 400 feet, or, at most, 450 feet, or that it extends ajown into the basal beds of the Chitistone limestone. It is evident, however, that the Bonanza is an exceedingly rich and unusual body of copper ore.

\section{JUMBO CREEK.}

From the Bonanza mine the Chitistone limestone continues northwestward in a succession of lofty cliffs as far as Kennicott Glacier. The base of these cliffs is at the greenstone contact, and in many places contains veinlets and stringers of azurite or chalcocite. In at least two places the quantity of these two minerals, especially of the chalcocite, is such as to make the deposits of commercial importance.

The ore body of the Jumbo claim is 4,600 feet northwest of the Bonanza, at the head of Jumbo Creek, and is located in limestone just above the greenstone-limestone contact on a small southwestward projecting spur or angle of the limestone cliff. South of it and nearly 200 feet below is the glacier in.which Jumbo Creek heads and which must be crossed to reach the ore body. The Jumbo and Bonanza ore bodies are at practically the same elevation above sea level, approxi1 mately 6,000 feet.

The limestone at the Jumbo is made up near the base of slightly cherty beds ranging in thickness from 8 to 12 inches. The strike is N. $65^{\circ} \mathrm{W}$., the $\operatorname{dip} 35^{\circ} \mathrm{N}$. A tunnel 12 feet long was started on the south face of the ridge, 10 feet above the greenstone. 'The limestone is jointed or cut by minor faults parallel to the bedding and is crossed by veins of calcite from 1 to 2 inches thick. Thin veins of chalcocite and azurite accompany them and fill some of the fractures. Seven feet above the tunnel mouth is the east end of a large chalcocite mass, which is well exposed on the axis of the ridge. As indicated on the surface, this body of ore is a mass of solid chalcocite 30 feet long, 6 feet by 4 feet 6 inches at the west end, and tapering to a diameter of 1 foot at the east end. It appears to be a rudely lenticular or possibly a conical body, but has irregularly shaped protuberances, as may be seen at the west end, where the steep west face or slope of the spur gives a cross section of the ore body. (See fig. 8.)

A little way east of the Jumbo tunnel is a second tunnel in limestone a short distance above the greenstone. The tunnel runs nearly north or slightly to the northeast in limestone that strikes N. $65^{\circ} \mathrm{W}$. and dips $25^{\circ} \mathrm{N}$. In the tunnel, which is 12 feet long, the limestone is crushed and jointed. Small veins of calcite and azurite up to $2 \frac{1}{2}$ inches in thickness fill joint cracks, especially a set of perpendicular minor faults or slip planes running $\mathrm{N}$. $70^{\circ} \mathrm{W}$. No chalcocite is exposed in the tunnel, but it is believed that the azurite indicates its former presence. Fifty feet below the tunnel a lenticular vein of 
chalcocite, 3 inches thick at its widest part and 3 feet long, was found in the limestone.

Northwest of the Jumbo claim and nearer Kennicott Glacier is another chalcocite body, the Erie, of similar character, that is said to be larger than the Jumbo. This property was not visited by the Survey party, nor was the Independence group of claims visited, which lies 900 or 1,000 feet below the top of the ridge between Bonanza and McCarthy creeks, on the McCarthy Creek side. The vein of the Independence is in greenstone, and is described by Mendenhall ${ }^{a}$ as being a fairly persistent fissure vein from 6 to 8 inches wide and trending obliquely to the limestone-greenstone contact. The

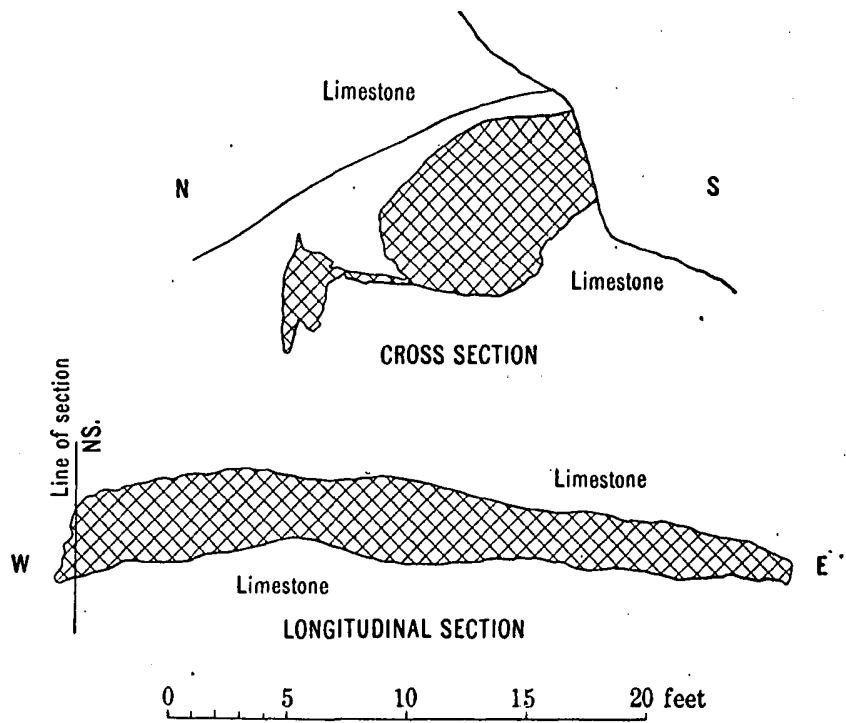

Fig. 8.-Sketch of the ore body at the Jumbo claim.

ERIE AND INDEPENDENCE CLAIMS.

vein mentioned is one of a number that occur in .a sheeted zone strik. ing N. $38^{\circ}$ E. and made up of a number of small fissures, most of which contain considerable calcite. This zone passes from the greenstone into the limestone, and has its greatest width, about 50 feet, at the contact. The ore is found in the greenstone only, and consists essentially of chalcocite, which fills fracture openings and permeates the greenstone between them. In places the chalcocite is present as amygdaloidal fillings in the greenstone. It is later than the calcite filling of the sheeted zone, and gradually disappears with increasing distance from the zone of mineralization. The main shear zone intersects a system of quartz-epidote veins striking N. $78^{\circ} \mathrm{E}$. and carrying

${ }^{a_{M}}$ Mendenhall, W. C., Geology of the central Copper River region, Alaska: Prof. Paper U. S. Geol. Survey No. 41,1906 , p. 104. 
a small amount of bornite. Except for the absence of chalcocite bodies in the limestone, there is a marked similarity between the occurrence of copper minerals in this locality and that at the Bonanza.

NIKOLAI CREEK.

The Nikolai mine, on Nikolai Creek, a tributary of McCarthy Creek emptying into Kennicott River a short distance below the glacier, was not visited by the Survey party, as no work has been done there since the claim was patented, and the shaft was reported to be filled with snow and ice. The following description is quoted from the report of Schrader and Spencer. ${ }^{a}$

Nikolai mine.-The Nikolai mine is located on the creek of the same name, tributary to McCarthy Creek from the east. [See Pl. X, A.] The occurrence has probably been known to the natives for a long time, and was revealed by an Indian named Jack to Mr. Edward Gates, who, though he had never visited the locality, was able to find it with the aid of a map drawn by Nikolai, late chief of the Taral Indians.

The Nikolai mine is situated 1,000 feet or more above timber line, at an elevation of 4,200 feet. The country rock in the lower part of the creek is Triassic shale intruded by porphyry, but a great fault brings up the Nikolai greenstone, which forms the bed rock from the vicinity of the main forks of the creek to a point above the mine. On the south side of the gulch, opposite the mine, the greenstone is opposed by the unconformable beds of the Kennicott formation, but to the north the Chitistone massive limestone is seen dipping steeply into the mountains, and this is followed by the Triassic shales, covering a large area between McCarthy Creek and Nizina River.

The vein occurs in the greenstone at a horizon not more than 50 feet below the bottom of the limestone, which outcrops in the creek bed a few hundred feet above the shaft. It is a true fissure vein, with well-marked walls, and there has been displacement or faulting along it to the amount of perhaps 50 feet, with the upthrow on the northwest. The course of the fissure varies from N. $50^{\circ}$ E. to $\mathrm{N}$. $55^{\circ} \mathrm{E}$., and the vein dips about $65^{\circ} \mathrm{SE}$. It may be traced for several thousand feet, though it shows no ore on the surface except near the place of discovery. The main fissure is paralleled at a distance of 90 and 140 feet, respectively, by two fissures which, though less prominent, also contain copper minerals, and the rock between is cut by many stringers of ore. In the vicinity of the shaft the main vein has a width of from $S$ to 12 feet and is divided about equally by a horse of greenstone 3 or 4 feet. across, in which the shaft has been sunk. The ore on either side of the horse is practically pure bornite, with only a small amount of quartz associated in an irregular way. Locally, as shown near the creek bed, there is a band of chalcopyrite lying next to the hanging wall. The development in the latter part of August, 1900, consisted of a shaft 30 feet in depth, and an open cut along. the vein for perhaps 50 feet. Throughout this distance ore having a thickness of from 2 to 4 feet had been exposed, and in the bottom of the shaft the horse had been penetrated and bornite ore was found on the foot-wall side. The development has been sufficient to show the presence of a large shoot of ore which can be mined from the present shaft or from a short adit which could be driven to cut the vein at a depth of perhaps 100 feet, but whether the

a Schrader, F. C., and Spencer, A. C., Op. cit., pp. 86-87. 


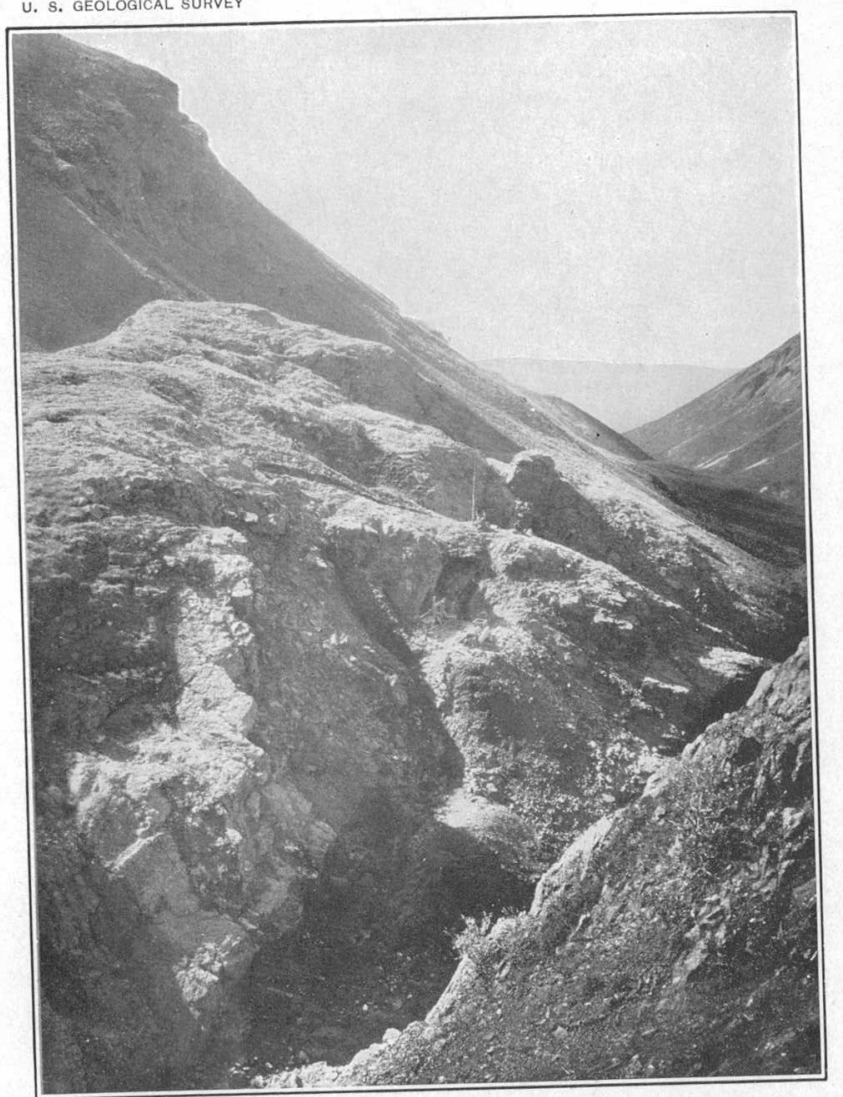

A. NIKOLAI VEIN AND SHAFT.

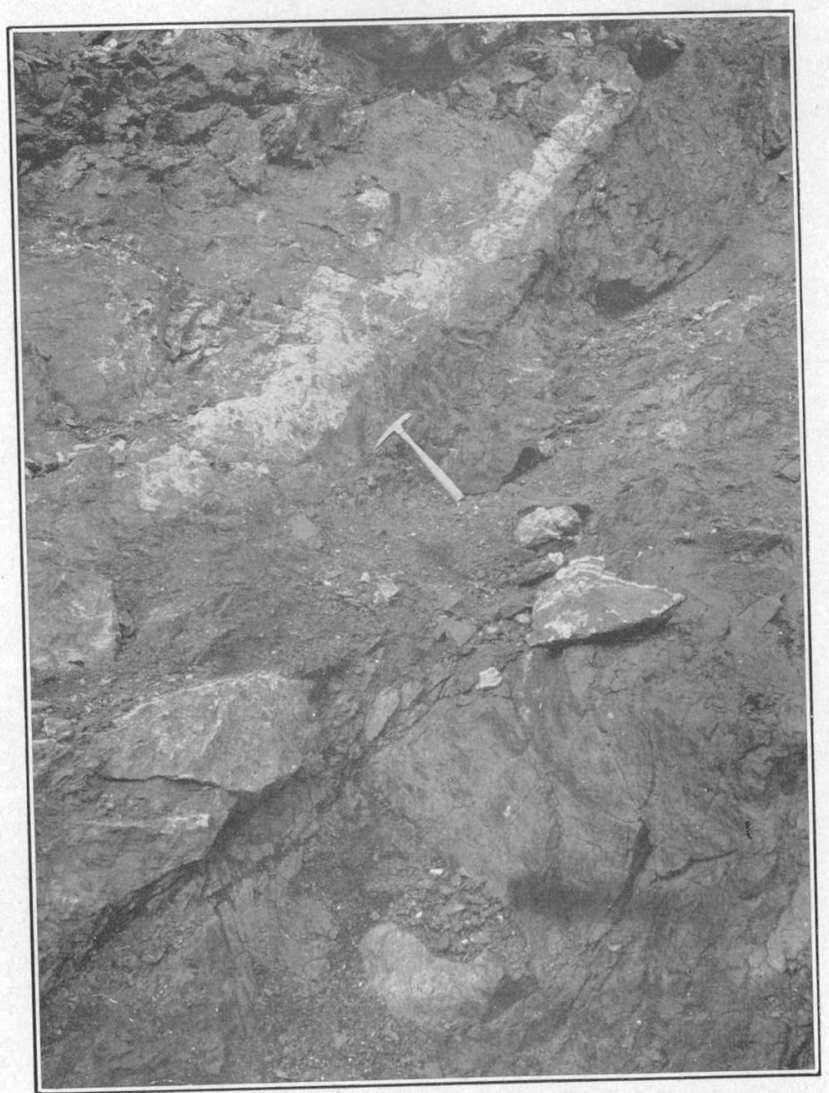

B. VEIN OF HENRY PRATHER CLAIM.

Looking north. Hammer marks foot wall. 
ore is generally distributed or whether there are other large ore bodies along its course is yet to be determined.

A good trail, a mile or more in length, has been constructed from the camp at timber line to the mine. During the summer of 1900 about a dozen men were engaged in the exploitation of the Nikolai mine.

CHITIST'ONE RIVER BASIN.

MAIN S'TREAM.

Chitistone River is a southwestward-flowing tributary of the Nizina and joins that stream approximately 30 miles above its mouth. It heads in the glaciers which cover the divide between Copper and White rivers, and its valley is one of the routes by which prospectors reach Skolai Pass and the White River Glacier. Between the lower end of the Chitistone Glacier and Nizina River the stream has a length of 18 miles, but the copper properties on which most work has been done are situated within the lower 10 miles of the valley. Within this lower 10 miles Chitistone River flows over a broad gravel-covered flat, ranging in width from one-half to 1 mile. The largest tributaries are Glacier and Toby creeks, both flowing in a northwesterly direction and joining the main stream within 2 miles of each other. The mouth of Glacier Creek, the more westerly of the two tributaries, is 7 miles from Nizina River. The larger tributaries, including two or three besides the two named, have broad gravel-covered valley floors similar to that of the Chitistone itself, but much narrower and with higher gradients. The smaller tributaries tumble down steep, rock-walled gulches.

For more than half its length the valley of Chitistone River is cut in Nikolai greenstone and the overlying heavy Chitistone limestone. In this vicinity the limestone reaches the maximum thickness observed, at least 2,000 feet. South of the river it dips gently northward, forming a conspicuous cap on the greenstone that may be seen for many miles to the southwest, and everywhere it lies at least 1,000 feet above the valley floor. On the north side of the river, between Nizina River and Glacier Creek, the whole mountain mass, except two or three hundred feet at the base, is Chitistone limestone extending to an elevation of more than 4,000 feet above the valley. On the west side of Nizina River the limestone is seen to dip to the north at about $30^{\circ}$, so that the great thickness on the east side represents the central low-lying portion of a large syncline. Farther up the valley Triassic and other younger rocks with granular intrusions and included coal beds appear.

Copper is found on Chitistone River in both the greenstone and the limestone, but in 1907 development had not revealed any considerable ore bodies. On the Chitistone itself most of the work had been done by the Houghton Alaska Exploration Company and by 
the Alaska United Copper Exploration Company, the first-named company directing its efforts to prospecting claims north of the mouth of Glacier Creek on the north side of the river and to claims on the south side of the river about 4 miles below Glacier Creek, and the second to prospecting ground on Contact Gulch opposite the mouth of Toby Creek. A large number of claims have been staked, including practically all of the limestone-greenstone contact, but some of them show nothing but the green carbonate stain.

Glacier Creek, among the tributaries of Chitistone River, is at present the area of greatest promise. Native copper is the ore chiefly found.

The property of the Houghton Alaska Exploration Company west of Glacier Creek on Chitistone River, on which most work has been done, lies at the limestone-greenstone contact 1,225 feet above the river valley. A tunnel 20 feet long follows a fault in the limestone running S. $30^{\circ}$ E. and dipping $70^{\circ}$ to $80^{\circ} \mathrm{E}$. This tunnel lies just above the greenstone contact at the top of a large limestone talus slope. Fifteen feet higher and 20 feet farther east is a slope about 25 feet long driven on the dip of a fault parallel to the bedding, which strikes N. $60^{\circ}$ E. and dips $35^{\circ} \mathrm{S}$. There is a fault zone of crushed country rock which has a thickness of 4 feet on the west side of the slope, but diminishes to 2 feet on the east side and practically dies out at a short distance from the mouth. It can be followed for 15 feet westward and is then cut off by a cross fault, giving it a lenticular cross section with a maximum thickness of 4 feet and a length of about 25 feet. The limestone is further cut by many small calcite veins. The fault zone is heavily impregnated with blue and green copper carbonate, accompanied by epidote. Iron oxide also is abundant in the crushed zone. The copper minerals penetrate the country rock, coating the joint planes with green carbonate, but azurite is almost restricted to the crushed zone.

The central camp of the Alaska United Copper Exploration Company is at the mouth of Contact Gulch, opposite Toby Creek, and most of the summer's work was done in that vicinity; although the company owns many other claims. A large part of the season was consumed in the construction of a cabin and trails by which the prospects, situated over 2,000 feet above the mouth of Contact Gulch, may be reached. Bornite in greenstone is the principal ore, but not enough development has yet been done to reveal any large body of it.

GLACIER CREEK.

Native copper is found on Glacier Creek in a small gulch about 1 mile above the lower end of the glacier, or 6 miles above the mouth of the creek. This copper was known to the Indians, who broke out 
fragments from the bed rock. The outcrop is on the northwest side of a steep gulch 625 feet above the glacier and less than half a mile from it. The gulch is reached by a trail over a high rock cliff, by going along the north side of the glacier between the ice and the bank or by crossing diagonally from the south side of the glacier. Traveling along the glacier's side is dangerous because of almost continuous rock slides, and is not possible at all in some seasons.

The country rock is a series of bedded amygdaloidal greenstone flows, and the copper is seemingly restricted to a particular one of these beds. Nearly 75 feet above the creek, on the claim known as the Chiti, the greenstone is cut by a fault running N. $10^{\circ}$ E. and dipping $40^{\circ} \mathrm{W}$., almost parallel to a bed of greenstone filled with black amygdules, consisting of a mixture of copper oxide and carbonaceous matter, and cut by small veins of the same material. Above and below this bed, whose maximum thickness is 8 feet, is greenstone with quartz amygdules and only a small amount of the black mineral. In the main open cut the fault appears at first glance to form the hanging wall, but there is a small thickness, not over 2 feet, of the black amygdaloidal greenstone just above it. Thirty feet farther north along the strike the fault is at the foot wall, and here the black amygdaloidal rock has its greatest thickness, 8 feet. The main fault changes its direction here and strikes more nearly east and west. It is cut by minor faults and slightly displaced. The black amygdaloidal rock is covered by slide rock 50 feet south of the largest cut, but continues with decreasing thickness northeastward for about 200 feet. The large fault, however, is easily traced for not less than 300 feet.

Copper is present as malachite, native copper; chalcocite, and cuprite. Masses of native copper weighing several pounds are found, but it is present chiefly as small specks in the greenstone and the black amygdules and as thin sheets or leaves of about the thickness of paper and small stringers in the greenstone. The larger masses occur in sponge or netlike form inclosing country rock. The largest one seen in place was not over 8 inches in diameter, but a quartz vein 300 feet north of the main cut yielded a mass weighing about 60 pounds. The fault with traces of the black amygdaloidal rock and some copper are reported to be found still farther to the northeast, but were not followed.

\section{DAN CREEK.}

Dan Creek is the first tributary to Nizina River below the Chitistone, from which it is separated by a mountain mass made up of Nikolai greenstone capped by gently northward-dipping Chitistone limestone $(\mathrm{Pl} . \mathrm{X}, A)$. On the northern side of this mountain mass the limestone-greenstone contact at its lowest point is only a few hundred feet above Chitistone River. On the southern or Dan Creek 
side, however, it ranges from 2,000 to 4,000 feet above the stream $(\mathrm{Pl} . \mathrm{X}, B)$. A further description of the geography and geology of Dan Creek is given in the account of its gold placers on pages 97-99. Just below the contact, north of Dan Creek, the greenstone in many places is stained with copper green and contains small stringers and bunches of copper minerals, chiefly bornite. This is said to be particularly true of a zone of greenstone extending for a long distance along the contact and situated about 30 feet below it.

At the head of Boulder Creek, which joins Dan Creek below the canyon, is a claim called the Westover, belonging to the Alaska United Copper Exploration Company. The exposed ore is a mass of bornite at or just above the limestone-greenstone contact. This ore body is entirely in the limestone and is unusual in that the other known similarly. situated copper deposits of the eastern portion of the Chitina copper region are chalcocite rather than bornite. The surface exposure has a length, in a horizontal direction, of 30 feet and a maximum width of 8 feet. At one end the ore consists of nearly pure bornite, whose boundaries with the inclosing limestone are rather sharply defined. At the other end it gradually fades into the country rock. No development work has been done other than to clear away the face of the exposure.

GOLD.

THE NIZINA PLACERS.

\section{LOCATION ANID HISTORY.}

The Nizina placer district, as now known, embraces in a general sense the drainage areas of Dan, Chititu, and Young creeks, which flow into Nizina River from the east and south. Young Creek empties into the Nizina about 20 miles above its mouth, Chititu Creek comes in about 1 mile above Young Creek, and Dan Creek flows into the main river about 4 miles farther upstream.

The discovery and location of these placers in 1902 has been described by Mendenhall and Schrader. ${ }^{a}$ After passing through the stampede stage of exploration the Nizina district relapsed into a period during which a great many of the claims as originally located were worked only on a small scale in an unprofitable manner. From one cause or another much of the better ground was soon involved in lawsuits which, until last year, 1906, were not settled in a way to justify systematic work necessitating an investment of capital.

a Mineral resources of the Mount Wrangell district, Alaska: Prof. Paper U. S. Geol. Survey No. 15, 1903, pp. 59-61. 


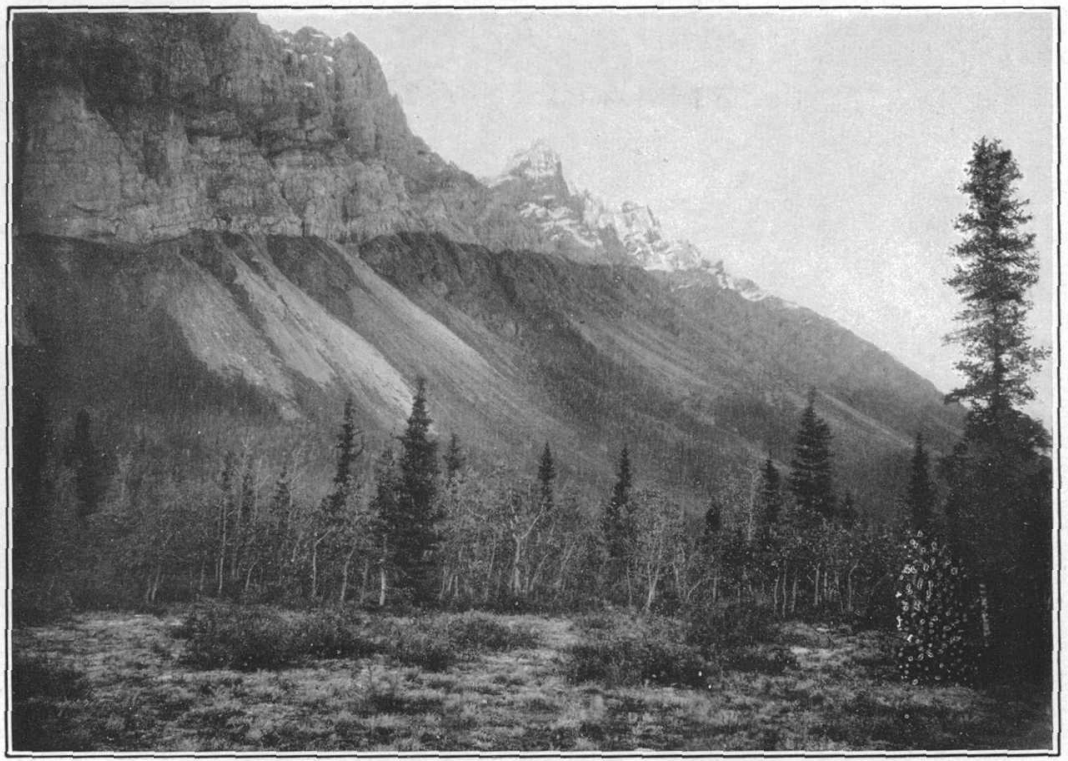

A. CONTACT OF CHITISTONE LIMESTONE AND NIKOLAI GREENSTONE. East side of Nizina River, about a mile below mouth of Chitistone River.

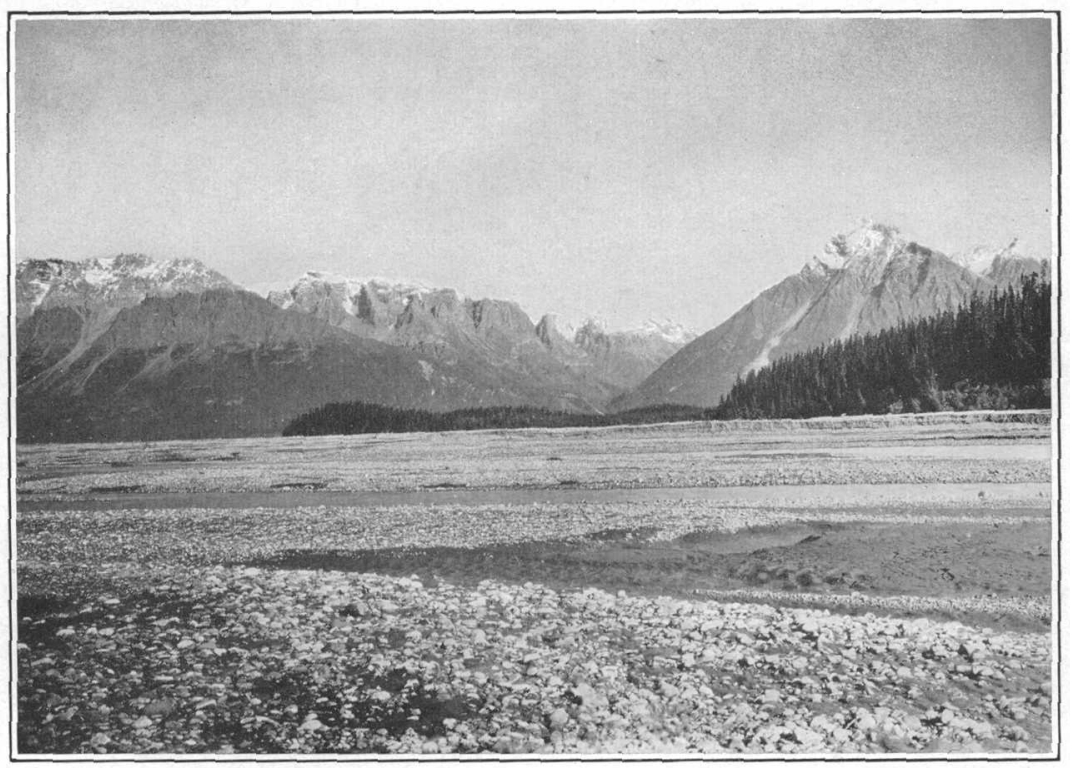

B. LOOKING ACROSS NIZINA RIVER INTO VALLEY OF DAN CREEK.

Chitistone limestone capping Nikolai greenstone on left; Triassic limestone-shale on right. 
GEOLOGIC SKETCH.

The bed-rock floor of this area is, so far as known, made up of a series of shales with a few thin limestones that are rather commonly intruded by dikes and sheets of light-colored porphyry. This bed rock on Chititu and Dan creeks is for the most part a dark, finegrained, homogeneous shale in which there is very little limestone. These shales are hard and closely jointed and have been intricately folded and contorted. They have also been subjected to faulting, some of which is very recent, as it has occurred since the unconsolidated Pleistocene bench gravels that lie unconformably upon the shales were deposited. It is probable that this shale bed rock is the floor upon which rests the thick sheet of bench gravel deposits that, so far as known, appear to extend from the northern slopes of the valley of Dan Creek along the gently sloping mountain sides that form the eastern side of the Nizina Valley to and probably beyond Young Creek. Schrader and Spencer represent the higher mountains to the east as made up of this series of shales and thin-bedded limestone.

The broad depression between the Skolai and Chugach mountains is floored by unconsolidated deposits, whose character and origin have already been discussed. A part of them was laid down in water; another part was deposited without sorting by water. The important deposits of the Nizina region, however, were mainly water laid and include the bench and stream gravels. Of the two the bench gravels are of less present commercial importance, although in amount they greatly exceed the stream deposits.

The general distribution of this thick gravel terrane appears to correspond to the benchlike surface feature that extends along the eastern side of Nizina Valley from Dan Creek to Young Creek and beyond in a southwesterly direction. The gravels apparently have their upper eastward limits about the middle altitudes of the mountain sides. They gradually slope down toward the west to an elevation of about 3,000 feet above the sea level, where the surface descends more abruptly for several hundred feet and thence continues on to the west for 2 to 6 miles as a gradually sloping valley floor to Nizina River, where the elevation is about 1,400 feet.

It is not known to what extent the distribution of the gravels may depend on the configuration of the rock floor beneath them, but considerable topographic irregularities exist both in slope of surface and in surface forms, giving rise to ridges, valleys, and hills such as would be presented by a rolling topography of moderate relief. These topographic features have been factors in the original distribution of the gravels, and their consideration is important in studying the Nizina placers, for the reason that at the present time the evidence 
points toward the bench gravels on this older land surface as being the source from which the supply of gold in the present stream or creek gravels is chiefly derived.

The view that the easily worked creek gravels of the present streams have received their gold from a source in the higher bench gravels is amply substantiated by the fact that the presence of gold in the bench gravels has been established. At several localities on Chititu Creek the bench gravels have been prospected systematically by tunnels following the bed-rock surface, and it has been found that gold is present in no inconsiderable amount, and that while the values are naturally highest on or near bed rock, yet considerable gold is present for some distance above bed rock. Under present conditions, however, it does not seem that the bench gravels can be worked profitably, though when supplies and labor can be obtained at lower cost it may prove profitable to mine them by tunnel and drift methods, or possibly by hydraulicking on a large scale. The bench gravels are not frozen, as are similar deposits in some parts of Alaska, consequently in working them by tunnels and drifts it is necessary to timber the workings thoroughly, an item of expense that increases the cost of such operations. It is by no means improbable that there may be old channels in the rock floor underlying these gravels where placer gold has been concentrated in amounts large enough to pay for mining by timbered tunnels and drifts. It may also be found that over some areas the bench gravels are not too thick to be profitably worked by hydraulic methods, even if a considerable thickness of overburden should have to be removed to reach the pay ground. Systematic and thorough sampling of large areas by drilling test holes should precede any contemplated installation for working gravels.

The present stream gravels of Dan, Chititu, and Young creeks are the deposits in which gold was first discovered and on which active operations are now being conducted. They are in part derived from the bench gravels and in part by the cutting of the streams in their own bed-rock channels. These deposits are more fully described in connection with the individual creeks.

The suggestion that the present auriferous creek deposits have been. derived from the thick mantle of bench gravels leads to a consideration of the source of the bench gravels and the placer metals they contain. Bowlders, cobbles, and pebbles of greenstone, with a considerable amount of native copper, are characteristic materials of the bench gravels. A few of these copper nuggets weigh more than 100 pounds, but most of them run about 1 or 2 ounces. The nearest known source for the greenstone and native copper of these gravels is on the north side of the valley of Dan Creek, and thence northward in the area of Chitistone River. Here are areas of greenstones in 
which some small amounts of native copper are known to occur, but no gold has been reported from these rocks. The following statements are quoted from the report by Mendenhall and Schrader: ${ }^{a}$

The rocks throughout the greater part of the district are reported by Schrader and spencer to be the black shales and thin limestones of the Triassic, but in the northern part of the basin of Dan Creek the Nikolai greenstone and the overlying heavy-bedded Chitistone limestone outcrop. There'is a doubtful region about the head of Young Creek, where these older rocks may also be found.

The black Triassic shales are reported to be intruded in this region, as they are known to be in other localities, by abundant porphyritic dikes, and the gold may be found to be genetically connected with these intrusives.

So far no facts have been brought to light to show whether the porphyry dikes in the Triassic shales may be a possible source of gold or not. On the other hand, it has been reported by a prospector that free gold occurs in the conglomerates of the Kennicott formation in this region. This formation has been assigned to the Upper Jurassic or Lower Cretaceous, and at present the only rocks of this age known to occur in the Nizina placer area lie south of Young Creek. There is also an area on the west side of Nizina River, opposite the mouth of Chitistone River. The Kennicott formation as now known occurs in isolated areas, of no very great extent, distributed from Kotsina River to the mountains south of Young Creek. It lies unconformably upon the Triassic shales and limestones and older greenstones. This series of conglomerates was no doubt formerly very much more widely distributed than it is at present. Extensive deposits of it have probably been entirely carried away by erosion, and if they were gold bearing, in part or as a whole, it can easily be seen how such a source might have supplied the present bench gravels in the Nizina district.

\section{CHITITU CREEK.}

The stream gravels of Chititu Creek (fig. 9) and its tributaries have received the most attention in this district. The upper half of Chititu Creek occupies a comparatively narrow valley that is excavated to a depth of 200 to 400 feet through the thick deposits of bench gravels and exposes the underlying shale. In this shale bed rock the stream has carved a trough from 200 to 700 feet wide and from 10 to 50 feet deep, conforming in slope with the surface of the rock floor. The trough is filled to a depth of 8 to 16 feet by recent stream gravels mainly derived from the adjacent bench gravels. In brief, the whole process has been that of a natural ground sluicing of the bench gravels. The bed-rock flume or sluiceway is paved with bowlders and cobbles, and in the natural riffles thus formed the gold and copper have been concentrated.

\footnotetext{
a Mendenhall, W, C., and Schrader, F. C. Prof, Paper U. S, Geọl, Survey No. 15, 1903, p. 61 .
} 
Only one of the original locators of claims on Chititu Creek has developed his holdings along conservative and consistent lines from the time of their discovery. On claim No. 11 above Discovery opencut work was begun with pick and shovel. During the second season canvas hose was used, and finally a small hydraulic plant with giants

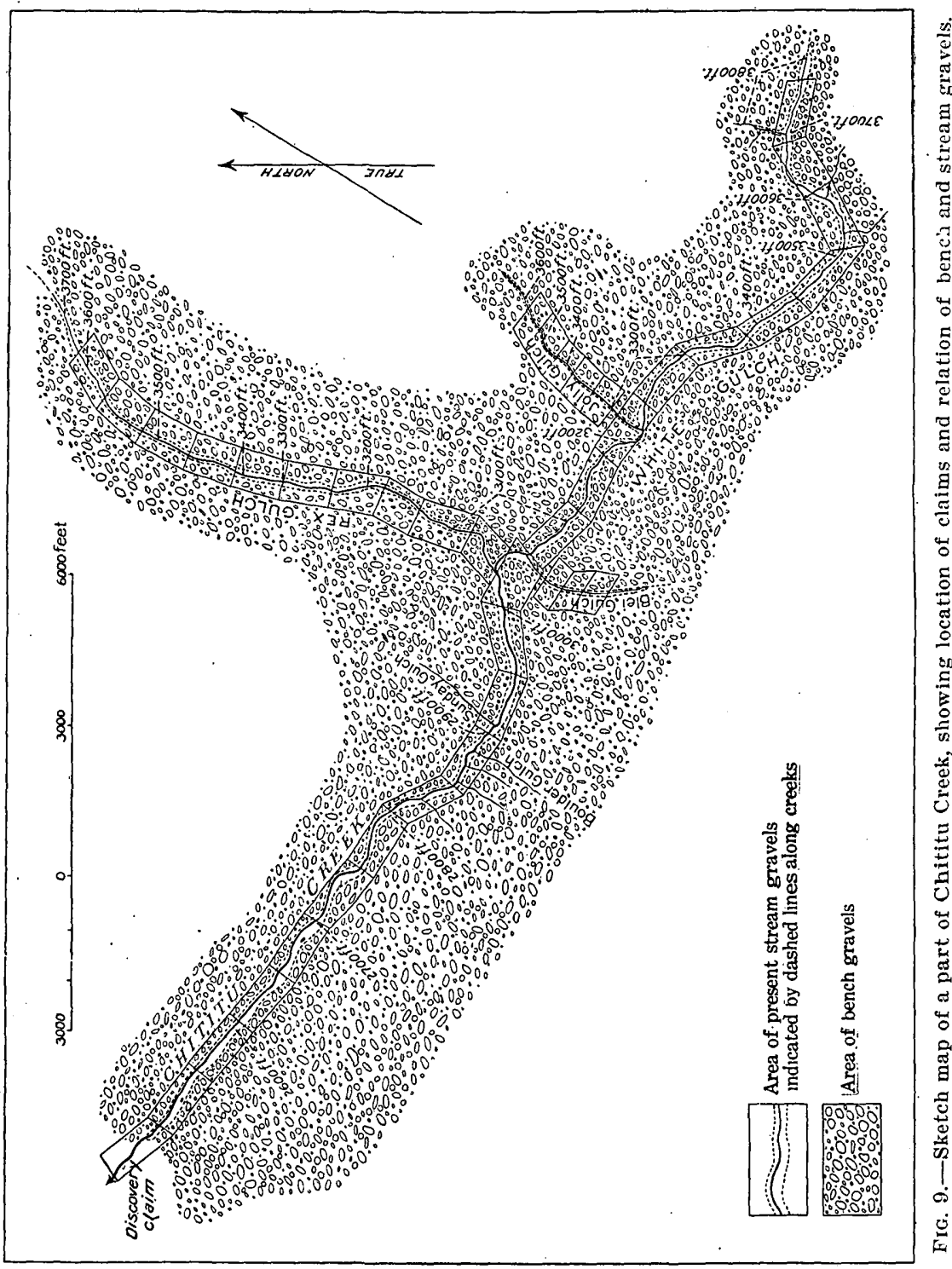

was installed. This plant has been improved from year to year and the results obtained have been increasingly satisfactory to the owner.

In 1907 active development work was begun on a group of claims that includes the major portion of the placer ground on Chititu Creek. A complete hydraulic plant, supplemented by a well- 
equipped sawmill run by water power and an electric-lighting plant to aid in night work during the latter part of the open season, was during the winter taken over the snow and ice to Chititu Creek from Valdez, a distance of 200 miles; by means of horses and sleds. This method of transportation is the only way by which any considerable quantity of material can be conveyed into the Copper River region at the present time. Even when economically conducted, on a large scale involving quantities of 100 tons or more, such transportation from Valdez to the Nizina district has never cost less than $\$ 130$ per ton. On small shipments the cost may be as much as $\$ 400$ per ton.

The greater part of the open season of 1907 was spent in installing this plant on the lower eight claims on Chititu Creek. The sawmill was erected on claim No. 4, above Discovery, to supply lumber for flumes, buildings, and other purposes. A large amount of hydraulic pipe was riveted together from the separate sheets, and as the season - progressed the whole plant, with dam and headgates on claim No. 8 above, the flume and pipe lines, lighting plant, etc., was assembled in working order, so that by the close of the season all arrangements were completed for beginning active mining on claim No. 1 with the opening of the season of 1908.

\section{DAN CREEK.}

Dan Creek, in point of size, is the first important tributary to Nizina River above Chititu Creek, and, as has been previously stated, is also the first one below Chitistone River. Its general course is westnorthwest; and it joins the Nizina at the point where that stream, flowing southward from the Skolai Mountains, abruptly changes its course to the west. The drainage area of Dan Creek covers approximately 45 square miles and is nearly as broad as it is long.

The stream for a distance of nearly a mile below the place where it emerges from the mountains flows across the gravel floor of the Nizina River valley, but is raised slightly above it by the broad, low, fan-shaped deposit of gravels it has brought down from above. The valley above this portion of the stream presents three different topographic features. For nearly 2 miles Dan Creek has cut its way through the deep bench gravels bordering the Nizina Valley and has excavated a shallow trough in the country rock. In this narrow trough the stream gravel is laid down. Above this portion the channel is in a narrow box canyon, which finally expands into the more open basin-like upper valley. Two principal branches unite above the canyon to form the main stream. The northern branch retains the name Dan Creek; the other is'known as Copper Creek.

The bed rock, as naturally exposed or as uncovered by mining operations along the lower part of Dan Creek, is made up of Triassic shales 68797-Bull. $374-09-7$ 
intruded by light-gray porphyritic and greenstone dikes. These shales, so far as is now known, occupy most of the area south of Dan Creek to Chitina River. North of Dan Creek is the Nikolai greenstone, overlain by a heavy capping of Chitistone limestone that forms the top of the mountain mass between Dan Creek and Chitistone River ( $\mathrm{Pl} . \mathrm{X}, B)$. The unnatural position of the Triassic shales south of the stream with reference to the greenstone north of it is believed to have been brought about by a great fault extending through the valley from southeast to northwest and. removing from view the Chitistone limestone which normally should be present between the greenstone and shales. This fault continues northwestward at least as far as Lakina River.

Placer mining is at present restricted to the areas above and below the canyon. Above the canyon most work has been done on Copper Creek. This part of the stream is difficult to reach with supplies, and only a few men were at work there in 1907 . Most of them were doing nothing but assessment work, and yet a few thousand dollars in gold have been produced during the several years since work began. The creek claims below the canyon are under one control, and, though the gold production has not been large owing to the difficulty of working the ground, prospecting has shown that gold is present.

Placer gold is associated with two classes of deposits, the present stream gravels and the older and much more extensive bench gravels. Mining or prospecting has been carried on in both of these. Undoubtedly a great part of the gold in the present stream is a concentration from the benches through which the creek has cut its channel. Whether any part of it has been brought by the present stream directly from its original source-that is, a source other than the higher unconsolidated bench gravels-to the place it now occupies, was not determined.

The first claim below the canyon is No. 7 and the numbers decrease downstream. Near the camp a cut approximately 400 feet long and as wide as the shovelers could work at one setting of the boxes was made in the creek gravels of claim No. 5. Directly above is a larger cut nearly as long and averaging about 75 feet in width. The bed rock is hard, close-jointed shale cut by dikes of light yellowish-gray porphyry and of greenstone. The gravel and its slight soil covering range in thickness from 8 to 12 feet. The gravel consists in part of shale fragments and contains a large percentage of greenstone and porphyry. Some of the bowlders in the large cut have diameters as great as 4 feet and many of them average 10 or 12 inches in maximum diameter. All of this material has been more. or less rounded by stream action. It is poorly bedded, and spruce logs and fragments of wood are buried in it. The large cut was made by piling up a wall of bowlders along the gravel face, thus forcing the creek water 
to undercut the bank and cause it to cave. Bed rock was then cleaned by hand. Such work is expensive, as it requires several handlings of all the larger material. A third cut, 300 feet long and one box wide, on claim No. 6 showed gravel and bed rock of the same character.

The width of the stream gravels is not great, in places not over 100 or 200 feet, but it increases down the creek. On each side benches of gravel close to the stream rise to a height of several hundred feet. Tunnels in these benches have demonstrated that they carry gold. One of these tunnels on the upper end of No. 6 or the lower end of No. 7 had a length of 72 feet. It was driven along the rock floor upon which the gravel rests and is 10 feet higher than the present stream. In other words, the creek has here cut 10 feet into the bed rock since the present drainage was established. The tunnel was driven in winter as a prospect and yielded good values in gold.

The Dan Creek gold from the gravels below the canyon is coarse and smooth. Most of it is flat, and the heaviest of it is found either on bed rock or within 2 feet of it. It is accompanied by placer silver and placer copper. Nuggets of silver and copper, such as are called "half breeds" in the Lake Superior region, are frequently found here and on Chititu Creek also. Copper is associated with both the creek and the bench gravels in pieces ranging from the size of shot to masses of 100 pounds or more. Only recently has any effort been made to secure the copper, as it is of no value with the present means of transportation. Most of the operators are now saving it, however, and when railroad transportation is available the returns from the copper may be found to reduce considerably the cost of mining.

The gold from Dan Creek above the canyon differs from most of that below in that it is generally rough and not flattened, indicating that it has not been hammered out and worn so much by moving bowlders.

Surveys for a hydraulic plant on the lower end of Dan Creek have been made, and it is expected that the installation of the plant will be begun during the summer of 1908 .

\section{REALGAR.}

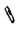

About one-third of a mile down Fourth of July Creek from the Bekka and Eli claims there is an occurrence of realgar (sulphide of arsenic). The mineral fills small spaces in a crushed zone in thinbedded limestones. Some of the spaces are filled for a width of 1 to 2 inches with well-formed crystals, but other seams contain the realgar in a more impure earthy form. The rest of the shatter spaces of the limestone are largely filled by thin seams of calcite. No considerable amount of realgar appears to be present at this place. 
COAL.

On the divide between Fourth of July and Bear creeks, north of the pass crossed by the trial, at elevations of 5,800 to 6,000 feet, is a small patch of coal-bearing shales and flaggy arkosic sandstones covering an oval-shaped area of about 20 acres. The thickness of these beds is probably not over 50 feet. They are partly covered by more recent andesite lava, that occupies a smaller area and stands at its highest point as a pinnacle about 50 feet high. These rocks, which may be provisionally assigned to the Tertiary, appear not to have been involved in the major fault that is well exposed on the head of Fourth of July Creek, which brings the Nikolai greenstone and Chitistone limestone to the north, against the thin-bedded limestones and shales to the south. The Tertiary coal-bearing beds seem to lie in a nearly horizontal position on top of the inclined beds of the older series. The coal was not seen in place, its presence being indicated only by small weathered fragments mixed with the disintegrated shales. It is probably not of workable thickness; and if it were, the small amount and its inaccessibility would prevent it from becoming of commercial importance 


\section{INDEX.}

A.

A bercrombie, W. R., work of..............

Alaska Kotsina Mining Co., claims of .......

Alaska surveys, plan of. .................

Alaska United Copper Exploration Co., claims of ..................... 90,92

Albert Johnson claim, description of. ....... 70

Allen, H. 'T., on copper deposits........... work of..

Altitudes, data on.

Ames Creek, copper claims on

Andesite, character and distribution of. . . . . 35-36

Azurite, distribution of

\section{B.}

Bekka claim, description of............. 79-80

Bibliography of region................. 10-11

Bonanza Creek, copper claims on ......... 80-86 description of ..................... 80

Bonanza mine, description of. .......... 80-86 discovery of . . . . . . . . . . . . . . . . 20 map of........................ 81 sections of, figures showing. . . . . . . 84,85

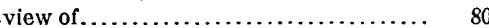

Bornite, distribution of . ............... $\quad 46$

Boulder Creek, copper claims on......... 92

Brooks, $\AA$. H., on geology of region........ 33,34 preface by

\section{C.}

California-Alaska Mining and Development Co., claims of. .................

Castle Mountain, rocks of. . . . . . . . . . . 35, 36 view of $\ldots \ldots \ldots \ldots \ldots \ldots \ldots \ldots \ldots \ldots . \ldots \ldots$

Chalcanthite, distribution of ............ 47

Chalcocite, distribution of. . . . . . . . . . 45-46

Chalcopyrite, distribution of............ 46

Chance claim, description of ............. 71

Chetaslina River, rocks on .............. 37

Chiti claim, description of ............. 91

Chitina River, bluffs of, view of . . . . . . . . 38 copper belt on, map of............. Pocket description of ..................... 12 explorations on................... 10 map of...................... Pocket

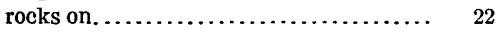

Chitina Valley trail, description of. ......... 14

Chitistone limestone, character and distribution of . . . . . . . . . . . . 21,25-28 copper in..................... 47-50 occurrence of, plate showing.......... 38 relations of . ............. 24-25, 29,33,37 plate showing. . . . . . . . . . . . . . 24-92

Chitistone River, basin of, copper claims in.. 89-92 coal on ..................... 32-33,42-43 copper claims on................ 89-90
Chitistone River, description of............ $\quad 89$ rocks on..................... 26

Chititu Creek, copper on................ 45 gold on ................... 94,95-97 map of . . . . . . . . . . . $96 \ldots \ldots \ldots \ldots \ldots . . \ldots$ rocks on . . . . . . .

Cliff claim, description of.............. 71 Climatic conditions, description of........ 18-19 Coal, character and distribution of..... 42-43, 100. Coal-bearing rocks, character and distribution of . .................. $32-33,99$ relations of . . . . . . . . . . . . . . . . $32-33$

Contact Gulch, copper claims in........... g()

Copper, early discovery and use of. ...... $7,19-20$ mining of...................... 42-43 geological occurrence of .............47-50. growing importance of................ 9 ores of, character and derivation of...... 50-54 zones of..................... 51-52 Copper claims, detailed descriptions of. 43-44,54-92 Copper Creek, copper claims on.......... 62-63 Copper King claim, description of . . . . . . . 65-66 Copper minerals, description of .......... 44-47 Copper Queen claim, description of........ 66 .

Copper River, description of............ 11 map of . ...................... Pocket. railway routes along............... 16-18. Copper River region, exploration of........ 7 Cordova Bay, description of ............ 17 railroad route from ................... Cretaceous rocks, character and distribution of........................... 21 Cuprite, distribution of............. 45 . D.

Dan Creek, copper claims on.......... 45,92 description of................. 91-92 gold on ................... 94,97-99 rocks on $\ldots \ldots \ldots \ldots \ldots \ldots \ldots \ldots \ldots \ldots 26,97$ view of $\ldots \ldots \ldots \ldots \ldots \ldots \ldots \ldots \ldots \ldots \ldots, \quad 92$

Deception Creek, copper claims on........ 70-71 Dikes, character and distribution of . . . . . . 34-36. Diorite, character and distribution of ..... 35,36 .

\section{E.}

Economic geology, account of.......... 42-100

Elevations, data on.................. 11

Eli claim, decription of . . . . . . . . . . . . $79-80$.

Elizabeth claim, description of........... 69

Elliott Creek, copper claims on ........... 65-71

description of .......................

map of, showing claims.............

rocks on, view of $. \ldots \ldots \ldots \ldots \ldots \ldots \ldots . .38$

section on, figure showing ........... (65)

Erie claim, description of............. 87-88. 
F.

Erosion, period of progress of. .

Fall Creek, copper claims on

Faulting and folding, occurrence of . ..... 29-30,32

Faults, distribution of.................... 37

Field work, outline of. ................... 9-10

Fohlin Creek, rocks on ................... 31

Fourth of July Creek, copper claims on ....... $79-80$ realgar on .......................... 99

Fourth of July Pass, coal near.............. 32

Freight, transfer of ..................... 13-14

\section{G.}

Gabbro, character and distribution of...... 34 Geography, sketch of..................... 11-18

Geologic map of region.................. Pocket comment on .................... $7,20-22$

Geology, account of . .............. 20-42

Gerdine, T. G., work of................ 8,10

Gilahina River, description of........... 12 rocks on view of........................ 28

Glacial deposits, character and distribution of . . ................. $36,38,39-41$

Glaciation, history of .................. 40-41

Glacier, railroad route over................ 18

Glacier Creek (of Chitistone River), copper craims on . 90-91

Glacier Creek (of Kennicott River), copper claims on . . . . . . . . . . . $79-80$

Gold, mining of . ..................... 42 placers of, descriptions of. ............ 92-99 source of .......................... 94

Goodyear claim, description of . .........6 67-68 section of, figure showing.

Government trail, description of .......... 13

Granite, character and distribution of....... 34

Great Northern Development Co., claims of . . . . . .

Greenstone, meaning of ................. 23 See also Nikolai greenstone.

Guthrie claim, description of ............ 70

\section{H.}

Hayes, C. W., work of .

Henry Prather claim, description of........ 68-69 view of ............................ 88

Hidden Creek, copper claims on . .......... 78-79 description of . . . . . . . . . . . . . . . $77-78$

History, outline of................... 19-20

Horse feed, supply of ................... 19

Houghton- $\mathrm{Alaska}$ Exploration Co., claims of.. 89-90 Hubbard claim, description of ........... 59-60 Hubbard Elliott Copper Mines Development Co., claims of.

Igneous rocks, character and distribution of . . . . . . . . . . 21-22,34-37

Independence claim, description of ........ 87-88 Intrusive rocks, character and distribution of.

J.

Jumbo claim, description of. ........... 86-87 ore body of, section of ................ 87 Jumbo Creek, copper claims on........... 86-88
K.

Page.

Jurassic rocks, character and distribution of. . 21

Katalla, harbor of ...................... 17

- railroad route from................... 10

Kennicott formation, character and distribution of. ................ 21,30-32,95

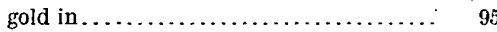
relations of ....................... 30

Kennicott Mines Co., claims of ............. 80

Kennicott River, basin of, copper claims in.. 77-89 rocks on .......................... 29

Kluvesna Creek, copper claims on........ 60-61 rocks on ............................ 25

Kotsina Mining Co., claims of........... 57,60

Kotsina River, basin of, copper claims in... 54-71 copper claims on .................. 54-55 description of....................... 12 rocks on.............. 23-25, 29, 30,34,36,37 view of ....................... 24

Kotsina trail, description of................ 14

Kuskulana River, basin of, copper claims in . . 71-74 description of....................... 71 rocks near..................... 25,29,35

L.

Laddie claim, description of ............. 59

Lakina River, basin of, copper claims in. .... $75-77$ description of ..................... $74-75$

Lakina River, fault at.................... 37 rocks on........................ 25,29 Lawton claim, description of . .......... $70-71$

Leland claim, description of ............... 70-71

Lime Creek, copper claims on.............. 55

Limestone Creek, rocks on................ 30

Literature, list of . . . . . . . . . . . . . . . . 10-11

Lizzie G. claim, description of ............ 67

Location of region....................... 11

Louise claim, description of............... $66-67$

M.

McCarthy Creek, rocks on

M.

Malachite, distribution of................ 46-47 Map of Chitina-Copper River region....... Pocket Map, geologic, of Chitina copper belt..... Pocket Maps of region, comment on............ 7-8, 20-21 Marie Antoinette claim, description of..... $69-70$ Marmot claim, description of ............. .66 Mendenhall, W. C., on Chitistone limestone.. 27 on valley-plain deposits............... 41 work or............................ 10

Mendenhall, W. C., and Schrader, F. C., on Nizina placers............... 95

Minerals, description of. $\ldots \ldots \ldots \ldots \ldots \ldots \ldots .44-47$ Mineral King claim, description of.......... 65-66 .Mint claim, deseription of ............... 58 Mountain claim, description of............. $\quad 58$ Mount Wrangell, rocks of................ 36 Mullen claim, description of. .............. $62-63$

$$
\mathrm{N} \text {. }
$$

Nebesna River, rocks on................. 33

Native copper, distribution of............ 44-45 huge nuggets of. : .................... 57,74

Navigation, character of ................. 14-15 
Nebraska claim, description of............. Page.

Nikolai, on copper .................. 19, 20

Niknolai Creek, copper claims on ......... 88-89 rocks on ....................... 26, 31 view on $\ldots \ldots \ldots \ldots \ldots \ldots \ldots \ldots \ldots . \quad 30$

Nikolai greenstone, character and distribution of.

copper in $44-45,47-50$ relations of. ............... 24-25,30,33,37

plates showing................. 24,92

Nikolai mine, description of . . . . . . . . . 88-89 rocks near, view of . ............... 24 view of ....................... 88

Nizina River, basin of, gold placers in . . . 42,92-99 basin of, gold placers in, discovery of . . . 20, 92 description of................... 12 faults on ........................... 37 rocks on and near........ 26, 29, 33, 35, 93-95 plates showing. . . . . . . . . . . 24,92 view on $\ldots \ldots \ldots \ldots \ldots \ldots \ldots \ldots \ldots \ldots, 92$

Nugget Creek, copper claims on ....... 45, 72-74 huge nugget on ................... 74 rocks on ....................... 34

0 .

One Girl claim, description of. $73-74$

\section{P.}

Peacock Creek, copper claims on......... 57-58 Placer copper, character and distribution of. . $\quad 50$ Pleistocene deposits, character and distribution of. $37-42$ view of .

Porphyry, character and distribution of . . . . 35, 36 Prince of Wales Island, copper of......... 9 Prince William Sound, copper of......... 9

\section{Q.}

Queen Creek, copper claim on............

\section{R.}

Railroad routes, description of. 15-18 grades of, chart showing ............. 16

Rainbow Creek, copper claims on ........ 66-67

Realgar, occurrence of................ 99

Recent deposits, character and distribution of $39-42$

Roaring Creek, copper claims on......... 56-57

Rock Creek, copper claims on . . . . . . . . 55-56 rocks on, view of . .................. 28

Rohn, Oscar, work of ............... $10^{\circ}$

Rose claim, description of . . . . . . . . . . 57-58

S.

Schrader, F. C., and Mendenhall, W. C., on Nizina placers.................

Schrader, F. C., and Spencer, A. C., on copper deposits.

on Nikolai mine.
Schrader, F. C., and Spencer, A. C., on rocks of region. . . . . .

work of $\ldots \ldots \ldots \ldots \ldots \ldots \ldots \ldots \ldots \ldots \ldots 7,9,10$

Schuchert, Charles, on Chitistone fossils.... 27

Schwatka, Frederick, work of............ 10

Sheehan claim, description of............ $\quad 59$

Shower Gulch, copper claims in . . . . . . . $58-59$

Skolai Mountains, location of............. 11

Skolai Pass, rocks at. . . . . . . . . . . . . . . . 29

Spencer, A. C., and Schrader, F. C. See Schrader and Spencer.

Stanton, T. W., fossils identified by ... 27-28,31-32

Steamboats, use of . . . . . . . . . . . . . 15

Stratigraphy, account of . . . . . . . . . . . 20.

Streams, description of . . . . . . . . . . . 11-12

Strelna Creek, copper claims on.......... $\quad 7_{4}$

rocks on ....................... 30,34

Surprise Creek, copper claims on ........ $59-60$ rocks on ......................... 35

T.

Tanana River, rocks on. :.............. 33

Tasnuna-Copper River route, description of . ................... 13-14, 17

Tenorite, distribution of............... 45

Tertiary volcanics, character and distribution of ........................ 33-34 Tonsina route, description of ........... 116

Topography, description of . .......... 11-13, 38 development of . . . . . . . . . . . . . . 38-42

Trail Gulch, rocks in . .............. 30

Trails, description of ................. 13-15

Triassic rocks, character and distribution

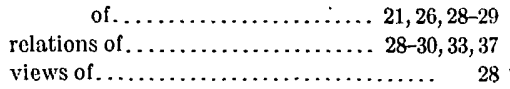

\section{V.}

Valdez, railroad routes from ............ 15-10

Valdez claim, description of. . . . . . . . . . 72-73

Valdez Exploration Co., claims of......... 78

Valdez series, character and distribution of . . 29,30

Valley-plain deposits, character and distribution of . . . . . . . . .

Van Dyke claim, description of........... 66

Van Hise, C. R., on derivation of copper ores. $\quad 51$

Vegetation, description of ............. 18-19

Volcanic rocks, character and distribution of. 33-34 Volcanism, period of . . . . . . . . . . $29-30$

W.

Westover claim, description of.......... 92

White Dog claim, description of ........... 58

Witherspoon, D. C., work of ........... 8, 10

Wrangell Mountains, description of........ 11

$\mathrm{Y}$.

Young Creek, gold on ............. 94-95

rocks on....................... 35

view of $\ldots \ldots \ldots \ldots \ldots \ldots \ldots \ldots \ldots \ldots \ldots \ldots \ldots \ldots \ldots \ldots \ldots, 34$ 